\title{
Crises and Government: Some Empirical Evidence ${ }^{\dagger}$
}

\author{
Jamie Bologna \\ College of Business and Economics \\ West Virginia University \\ Morgantown, WV 26506-6025 \\ em : jbologna@mix.wvu.edu \\ Andrew T. Young \\ College of Business and Economics \\ West Virginia University \\ Morgantown, WV 26506-6025 \\ ph: 3042934526 \\ em : Andrew.Young@mail.wvu.edu
}

\begin{abstract}
JEL Codes: E02, O11, O43
Keywords: sovereign debt crises, banking crises, currency crises, inflation crises, institutional quality, size of government, ratchet effect
\end{abstract}

This version: November 2014

Abstract: We examine a panel of 70 countries during 1966-2010 and utilize Reinhart and Rogoff crisis dates to estimate the effects of crises on the size and scope of government over both 5-year and 10-year horizons. We also estimate cross section regressions using 40-year (1970-2010) changes in government variables. Banking crises appear to be associated with decreases in the size and scope of government, while sovereign external debt crises are associated with increases. Otherwise, the size and scope of government appears to be persistent to the extent that even crisis episodes fail to leave a significant mark upon them. A notable exception may be that, over 40-year periods, countries that spend more years in crisis are associated with weaker legal systems and property rights.

$\dagger$ We thank Randy Holcombe, Jakob de Haan, and other participants at the 2013 Public Choice meetings in New Orleans for helpful comments; for the same, we thank participants at a Texas Tech Free Market Institute seminar. 


\section{Introduction}

In September of 2008 the world seemed to fall apart. What seemed like economic slowdown in 2007 deteriorated into financial crisis, first in the US, and then in Europe and elsewhere. The Great Recession had begun. Since then it is hard to scan the headlines without reading about an economic crisis of some sort, somewhere. From 2008 to 2010, worldwide there were 21 sovereign debt crises, 28 currency crises, and a staggering 46 banking crises. ${ }^{1}$

Google offers two definitions for the word crisis: (1) a time of intense difficulty, trouble, or danger and (2) a time when a difficult or important decision must be made. ${ }^{2}$ Undoubtedly (1) is an apt description of an economic crisis. Furthermore, the belief that governments take (2) to heart, intervening into markets and implementing policies intended to halt or mitigate crises, is widely held. There are recent examples to support this belief. The UK's 2008 bank rescue package, the 2009 American Recovery and Reinvestment Act (ARRA), and the EU's 2008 stimulus plan are three. These interventions are associated with large increases in government expenditures and scope of decision-making and control. Are such interventions the rule or are they exceptions; does their prominence exaggerate their generality? Moreover, if they are the rule, are the increases in government size and scope temporary expedients or long-lasting; even permanent?

This paper seeks to address these questions using data for up to 70 countries on economic crises from the 1960's through 2010. We estimate the relationship between crises and changes in the size and scope of government over both five year and ten year horizons. In doing so, we control for terms of trade shocks, foreign aid flows, fluctuations in oil rents, output gaps, internal conflicts, the initial size and scope of countries' governments, as well as period and cross-

\footnotetext{
${ }^{1}$ These numbers are based Reinhart and Rogoff (2011a) dates of crises.

${ }^{2}$ We Googled the word on June 1, 2013.
} 
country fixed effects. Unlike previous studies, we consider not only banking crises but also sovereign debt crises, currency crises, and inflation crises.

Rahm Emanuel, then chief of staff to US President-Elect US Barack Obama, was quoted as saying: "You never want a serious crisis to go to waste" ${ }^{3}$ His point (at least as widely interpreted) was that a crisis "creates a sense of urgency[;] actions that once appeared optional suddenly seem essential. Moves that might have been made at a leisurely pace are desired instantly" (Seib, 2008). In other words, a crisis facilitates political actions that, from the policymaker's perspective, would have been desirable regardless of a crisis having occurred. Presumably, then, these political actions are not temporary expedients.

The economic historian Robert Higgs (1987) proposes a theory that is also consistent with temporary crises resulting in permanent expansions in government. Higgs argues that, during a crisis, individuals' beliefs in the efficiency of markets weaken. The demand for government intervention increases as a result. Increasing the scope for government interventions often requires a relaxing of constitutional constraints which will tend to persist beyond the crisis period. Furthermore, people become accustomed to the larger and more interventionist government. For these reasons, Higgs argues that while the size and scope of government may recede after the crisis, it is unlikely to return to its pre-crisis levels. Higgs refers to this as a ratchet effect. Government growth is path dependent; crisis episodes introduce expansions in the size and scope of government that have a permanent component.

However, the Higgs' (1987) perspective and responses to the Great Recession might be interpreted as at odds with the conventional wisdom. Pitlik and Wirth (2003, p. 565) note that it

\footnotetext{
${ }^{3}$ Rahm Emanuel made the statement in November of 2008; it was a rephrasing of the economist Paul Romer's 2004 statement: "A crisis is a terrible thing to waste." Source: $\underline{h t t p: / / w w w . n y t i m e s . c o m / 2009 / 08 / 02 / m a g a z i n e / 02 F O B-~}$ onlanguage-t.html.
} 
is "commonly shared wisdom among economists and political scientists" that crises promote the adoption of market-oriented reforms. ${ }^{44}$ To the extent that market-oriented reforms can also be characterized as decreases in the size and/or scope of government, this point of view runs counter to that of Higgs. Pitlik and Wirth cite a number of examples that support this "commonly shared wisdom", including Latin American country reforms at the beginning of the 1980s and the reforms made by transition economies in the wake of the Soviet Union's demise. ${ }^{5}$ According to this view, crisis periods represent what one might call moments of clarity for politicians; realizations that bad policies must be changed or removed to avoid economic collapse (Harberger, 1993; Williamson and Haggard, 1994). Furthermore, Alesina and Drazen (1991) and Drazen and Grilli (1993) argue that particular reforms impose costs on particular special interests, and that conflicts over the distribution of such costs delay reforms generally. Economies become "sclerotic", to use Olson's (1982) term. During a crisis, however, more widely spread costs (i.e., those associated with the continuation of bad policies) increase, along with the likelihood that reforms occur.

We are therefore left with two somewhat opposing views. Do economic crises lead to permanent shocks that increase government size and scope; are there ratchet effects of the type described by Higgs (1987)? Or do crises present opportunities for market-oriented reforms, thereby reducing the size and scope of government? Furthermore, there is a third possibility: crises lead to political polarization and, as a result, gridlock that hampers any sort of reforms. Mian et al. (2014) report cross-country evidence that financial crises do lead to polarization and fractionalization. However, based on the information contained in the IMF structural reforms

\footnotetext{
${ }^{4}$ See also the literature review by Rodrick (2006).

${ }^{5}$ New Zealand in the middle of the 1980s and the experience of the UK during Thatcher's administration are also cited.
} 
database (Abiad et al. (2008) and Ostry et al. (2009)) the link between that increased polarization/fractionalization and the likelihood of financial reforms is unclear. While Min et al. (2014) focus on financial reforms (e.g., the liberalization of interest rate controls) their gridlock argument may also be applicable to the size and scope of government more generally.

The relationship between crises and government is ultimately an empirical question, and cursory looks at the data do not get us very far towards and answer. For example, consider the US case and the size of government. Figure 1 plots federal government expenditures as a share of GDP from 1929 through 2011. From 1929 through 1945 the share increased substantially, from less than $3 \%$ to a peak of over $31 \%$. This increase corresponded, undoubtedly, to the (economic and non-economic crises, respectively) crises of the Great Depression and World War II. Federal spending fell subsequently, but not to pre-crises levels. In fact, the share has since remained always above $14 \%$ (or more than 5.5 times the pre-crises share). A plausible interpretation is that government spending ratcheted. However, Holcombe (1993) argues that, after taking into account a positive trend in government growth during the twentieth century, the Great Depression/WWII ratchet is not a statistically significant event in the data. ${ }^{6}$ Of course, the US is only one particular case. Furthermore, as Higgs (1991) notes, expenditures are just one margin along which government growth can occur.

There are a fairly small number of studies that address the relationship between crisis episodes and the size/scope of government. For a sample of Latin American countries, Lora and Olivera (2004) report a positive relationship between severe episodes inflation and negative GDP growth and an index of "structural reform". ${ }^{7}$ For a broader sample of countries, Bruno and

\footnotetext{
${ }^{6}$ Sobel and Crowley (2012 forthcoming) find statistically significant ratchet effects for US state and local government budgets in response to federal grants during the 1995 to 2008 time period.

${ }_{7}^{7}$ Their index includes trade policy, tax policy, financial policy, privatization, and labor legislation components.
} 
Easterly (1996) find that high-inflation countries are more likely to subsequently achieve low, stable inflation than moderate-inflation countries. Drazen and Easterly (2001) follow their approach and report similar findings, not only for inflation crises but also for large increases in black market premiums. However, the occurrence of reforms (market-oriented or otherwise) is inferred from improved performance. Therefore their studies can say little directly about changes in the size/scope of government.

Most closely related to our work are the cross-country panel data studies of Pitlik and Wirth (2003), de Haan, Sturm, and Zandberg (2009) and Baier, Clance and Dwyer (2012). Pitlik and Wirth (2003) report that episodes of severe GDP contraction and inflation during a 5-year period are associated with increases in the Fraser Institute's Economic Freedom of the World (EFW) index during the subsequent 5-year period. The EFW serves as an (inverse) proxy for government size and scope. De Haan et al. (2009) study the effect of banking crises on the EFW. They report that banking crises increase government size in the short-run (i.e., 1 year) but decrease both the size and scope of government in the longer-run (i.e., 5 years). ${ }^{8}$

Baier et al. (2012) find that banking crises are associated with lower economic freedom scores up to 10 years later. However, several concerns about the Baier et al. study can be noted. Unlike de Haan et al. (2009) and Pitlik and Wirth (2003), they use the level rather than the change the EFW index as their dependent variable. They also do not control for the initial level of the EFW in their estimations. ${ }^{9}$ Furthermore, Baier et al. do not control for output gaps and foreign aid flows as de Haan et al do.

\footnotetext{
${ }^{8}$ This is based on estimated effects on the area 1 subindex (government size) and the area 2 index (legal structure and security of property rights).

${ }^{9}$ The de Haan et al. (2009) and Pitlik and Wirth (2003) specification seems more natural given the underlying theories: starting from some level of government size/scope (which must be controlled for) a crisis induces either and increase or decrease in government size/scope.
} 
We complement and build upon these previous studies in several ways. First, we consider not only banking crises, but also currency crises, inflation crises, and sovereign debt crises (both external and internal). Debt crises are of particular interest given their prevalence both during and subsequent to the Great Recession. These include the well-publicized episodes in Greece, Ireland, and Portugal. Furthermore, these sovereign debt crisis episodes may be perceived as failures of the public rather than the private sector; as such, their effect on the likelihood of market-oriented reforms may be different. For example, sovereign debt crises may not be accompanied by weakened beliefs in market efficacy as Higgs (1987) describes.

Second, while we control for initial government size/scope, output gaps, and foreign aid flows as de Haan et al. (2009), we additionally control for internal conflicts, oil rents, and shocks to the terms of trade that a country faces; all three of these variables may be important omitted variables in the de Haan et al. analysis. ${ }^{10}$

Third, given that we are controlling for the initial level of government size/scope as well as the likely presence of unobserved country-fixed effects, our OLS model is likely going to suffer from the bias present in dynamic panel models (Nickell, 1981). Therefore, we supplement the results with a system GMM estimation procedure as suggested in Arellano and Bover (1995) and Blundell and Bond (1998). In addition to using the lagged levels and first differences as

\footnotetext{
${ }^{10}$ Djankov et al. (2008) argue that both can create political instability that directly affects institutional quality (including government institutions). Several studies have reported that oil wealth is negatively correlated with the quality of political institutions (e.g., Ross (2001), Collier and Hoeffler (2009), Ramsey (2011), and Tsui (2009)); however, Brückner et al. (2012) find that, for countries with high oil wealth generally, positive oil price shocks lead to long-run increases in democratic institutions. Catão and Kapur (2006) find that terms of trade shocks are associated increased risk of government default; hence they are expected to be a determinant of debt crises. Rodrick (1998) reports that the well-documented positive correlation between openness and government size is strongest when the terms of trade are most volatile; openness is also a function of the government. Dawson (2010) finds that terms of trade shocks are an important omitted variable in regressions of macroeconomic volatility on an index of economic freedom; macroeconomic volatility is presumably a determinant of the probability of a crisis.
} 
instrumental variables, we include four exogenous instruments that are common in the institutional change literature.

Fourth, we define the short- and long-runs as 5-year and 10-year horizons, respectively. Our definitions contrast with de Haan et al. (2009) who treat 5-years as the long-run, and Pitlik and Wirth (2003) who consider 5-year periods only. Government interventions often take months to be instituted; years to be fully enacted. For example, the US ARRA stimulus was not passed until February 2009. As of April 2010 still only 65\% of the legislated ARRA spending had been announced, and only about $60 \%$ of that total had actually been paid out (Young and Sobel, 2013, table 1$).{ }^{11}$

Also, crises are themselves episodes lasting often for a number of years. For example, the average banking crisis in our sample lasts 3.75 years and 37 of them are at least 5 years long. ${ }^{12}$ We believe that it makes sense to define the long-run as longer than the typical crisis episode. We also believe that the 5-year versus 10 -year distinction is a more reasonable one for evaluating the Higgs (1987) ratchet effect hypothesis. Regarding his discussion of New Deal responses to the US Great Depression, Higgs is referring to expansions in government size and scope that occurred over several years and then partly receded only after WWII (more than a decade after the Depression's trough). If a ratchet effect is present, we may expect an increase in government size/scope in both the 5-year and 10-year periods, with the increase in the former being larger in magnitude.

Lastly, we also take an even longer-run perspective. Our data on the size and scope of government span up to 40 years, 1970-2010. We also utilize the crisis dates described in

\footnotetext{
${ }^{11}$ Fannie Mae and Freddie Mac, the government sponsored mortgage entities, were taken into conservatorship on September 7, 2008; the investment bank, Lehman Brothers collapsed on September 15, 2008.

12 The median duration is 3 years.
} 
Reinhart and Rogoff (2009 \& 2011) that are annual and go back considerably further. Together, then, these data allow us to estimate and report a cross-section regression related the total number of years spend in crisis during 1961-2000 on the overall change in our government measures during 1970-2010.

Summarizing our approach, we examine a panel of 70 countries covering the years 1961 to 2010. We estimate the relationship between a crisis episode during a 5-year or 10-year time period and the change in government size and scope during the subsequent 5-year or 10-year period. We also estimate the long-run cross section regression described in the paragraph immediately above. We measure the size of government simply as its expenditure share of GDP. Our proxies for the scope of government are the (i) legal system and property rights, (ii) regulation, and (iii) freedom to trade internationally area scores of the Fraser Institute's EFW index.

The results are generally very sensitive to the definition of the crisis variable, both for the 5-year and the 10-year analysis. Considering the statistically significant coefficient estimates, none of the patterns across the 5-year and 10-year horizons fit the Higgs (1987) ratchet hypothesis. There is relatively strong evidence that:

- banking crises are associated with decreases in a country's $G / G D P$ ratio in the subsequent 5-year period;

- banking crises are associated with subsequent decreases in the scope of government, in general, over both the 5-year and 10-year period;

- sovereign external debt crises are associated with subsequent increases in a country's $G / G D P$, over both the 5-year and 10 -year period; 
- $\quad$ sovereign external debt crises are associated with subsequent increases in the scope of government, in general, over both the 5-year and 10-year period.

However, given the robust finding of banking crises on government size and scope, the most remarkable result from the long cross section regressions is:

- all types of crises are associated with statistically significant 1970-2010 decreases in a country's legal system and property rights score.

We proceed with a description of the data and a preliminary analysis in section 2 . The results of our analysis are found in section 3 . We conclude in section 4.

\section{Data}

We use two panels, each consisting of data from the 1960's to 2010 for 70 countries. The first panel is divided into 8 time observations, each consisting of a 5 year time period where a crisis may be observed and a subsequent 5-year time period where a change in the size and/or scope of government may be observed. For example, a crisis observation during 1966-1970 is related to a 1970-1975 change in the size and/or scope of government. The second panel is divided into 4 time observations, each consisting of observations from sequential 10-year time periods. For example, a crisis observation during 1961-1970 is related to a 1970-1980 change in the size and/or scope of government.

In addition to the two panels, we also take an even longer-run perspective using data on the size and scope of government from 1970-2010 and data on the total number of years spent in crisis from 1961-2000. This allows us to look at the effects of crises on the size and scope of government over 40-year periods. Thus, we estimate and report a cross-section regression 
relating the total number of years spent in crisis during 1961-2000 on the overall change in our government measures during 1970-2010.

Our data can be broken into four categories: (i) measures of the size and scope of governments; (ii) dates and weights of economic crises; (iii) additional controls; and (iv) instrumental variables.

\section{i. $\quad$ Size and Scope of Government}

From the Penn World Tables (PWTs) version 7.1 (Heston et al., 2012) we utilize the government consumption share of GDP $(G / G D P)$ as a measure of the size of government. Concerning the scope of government, we utilize the Fraser Institute's Economic Freedom of the World (EFW) index constituent area scores (Gwartney et al., 2012). The EFW is designed to capture the extents of "personal choice; voluntary exchange coordinated by markets; freedom to compete in markets; and protection of persons and their property by others" (p. 1). We assume that the extents of personal choice, voluntary exchange, and private property protection are inversely proportional to the scope of government in the economy.

The EFW index has five constituent areas: (1) size of government, (2) legal system and security of property rights, (3) sound money, (4) freedom to trade internationally, and (5) regulation. Since we use the government expenditure share as a measure of government size, we do not focus on (1). Also, area (3) is in large part based on indicators of "the consistency of monetary policy (or institutions) with long-term price stability” (Gwartney et al., 2012, p. 6). Monetary policy is often perceived a fundamentally different than other government functions; and monetary policy agencies are often, by design, granted considerable institutional independence. Therefore we also do not focus on (3). 
We focus our analysis on the remaining three areas of the EFW: legal system and security of property rights (PROPERTY); freedom to trade internationally (TRADE); and regulation (REGULATION). These three areas encompass what we generally conceive of in thinking about the scope of a government. Is the government constrained by the rule-of-law, or does it play a more activist role in criminal and civil courts; shaping policy via the judiciary? Are private property rights secured against expropriation, or is it relatively easy for the government to allocate private resources into public utilization? Can firms and individuals trade with other countries freely, or does government play a large role in determining which goods and services will flow in and out of the economy? Are individuals and firms free to make consumption and production plans freely via markets, or does the government play a larger role in regulating those plans?

To the extent that the answers to these questions favor the latter alternatives, this indicates a greater scope of government in the economy. Each of the PROPERTY, TRADE, and REGULATION are scored on a 0 to 10 scale with 10 indicating the most free (and, by our interpretation, smallest government scope). Country scores are available back to 1970 .

We will use changes in G/GDP, PROPERTY, TRADE, and REGULATION as dependent variables in our regressions. For the 5 year panel, the observations will be changes over the 1970-1975, 1975-1980, 1980-1985, 1985-1990, 1990-1995, 1995-2000, 2000-2005, and 20052010 time periods. For the 10 year panel, the analogous time periods will be 1970-1980, 19801990, 1990-2000, and 2000-2010. Furthermore, in every regression we will control for the initial level of government size/scope (e.g., when the 1970-1975 or 1970-1980 change in PROPERTY is the dependent variable, one of the regressors will be the 1970 value of PROPERTY.) 


\section{ii. $\quad$ Crises}

We use the crisis dates described in Reinhart and Rogoff $(2009,2011)$. The Reinhart and Rogoff (henceforth RR) data is yearly and goes back to 1800 (though EFW availability constrains us to use RR data only from the 1960s onward). RR date five specific types of economic crises: banking crises, sovereign debt crises (both external and internal), currency crises, and inflation crises.

- Banking crisis $(B A N K)$ : episodes characterized by (i) bank runs that result in the public sector closing, merging, or taking over financial institutions and/or (ii) the large-scale public sector closing, merging, or taking over of an important (or a group of important) financial institution(s).

- External sovereign debt crisis (DEBT_EXT): episodes characterized by a government's repudiation of, restructuring of, or outright default on external debt obligations (i.e., liabilities to non-residents).

- Internal sovereign debt crisis (DEBT_INT): episodes characterized by a government's repudiation of, restructuring of, or outright default on internal debt obligations; in identification of internal crises the freezing or forcible conversion (from dollars to local currency) of bank deposits are considered failures to meet internal debt obligations.

- Currency crisis (CURRENCY): episodes characterized by an annual depreciation relative to the US dollar (or a relevant anchor currency) exceeding $15 \%$.

- Inflation crisis (INFLATION): episodes characterized by an annual inflation rate exceeding $20 \%$.

Reinhart and Rogoff (2008, Appendix) provide a comprehensive discussion of the details and issues surrounding their criteria for dating crises. 
In our panel regressions, crisis episodes occurring during a given (5- or 10-year) time period are regressors for the change in government size/scope during the subsequent time period. For example, in the 5-year panel we consider the relationship between BANK during 1966-1970 and the change in $G / G D P$ during $1970-1975$; the analog in the 10 year panel is a regression of the 1970-1980 change in G/GDP on $B A N K$ during 1961-1970. This raises questions concerning how appropriately to account for the timing and severity of crisis episodes. Specific and operational answers to these questions will necessarily be somewhat arbitrary. ${ }^{13}$ As much as possible, then, we remain agnostic and consider two different variants of the crisis variables.

First, we simply define dummy variables for each type of crisis that take the value of 1 if a crisis occurs during a specific 5-year (10-year) period; 0 otherwise. ${ }^{14}$ Figure 2 takes a preliminary look at the unconditional relationship between each of the crisis dummy variables and subsequent period changes in government expenditure shares. The left column of panels is based on the 5-year panel and the right column is based on the 10-year panel. Each row of panels corresponds to a specific type of crisis: from to top to bottom, BANK, DEBT_EX, DEBT_INT, CURRENCY and INFLATION. Nothing in figure 2 provides strong a priori evidence for ratchet effects, or simply economically meaningful increases in the size of government. Best fit OLS regression lines often negatively sloped (as for both the 5-year and 10-year horizons for both banking crises and internal sovereign debt crises). In all cases, the slopes are very small in absolute value. Figure 3 displays analogous relationships of crises to changes in PROPERTY, one of the EFW areas and a measure of government scope. In the 5-year and 10-year panels its

\footnotetext{
${ }^{13}$ De Haan et al (2009) simply employ a dummy variable (1 if crisis; 0 otherwise). Pitlik and Wirth (2003) weight crisis observations by years and severity.

${ }^{14}$ In addition to including each type of crisis separately, we also included a sum of all five types of crisis as a robustness check (TOTAL). Significant results from this estimation are given in Table 10; full results are available upon request.
} 
sample standard deviations are, respectively, 2.048 and 2.068. Not only are the best fit OLS lines almost always positively sloped for both the 5-year and 10-year horizons; the slopes are again very small relative to the sample variation in PROPERTY. Figures $\mathbf{2}$ and $\mathbf{3}$ both suggest that, an economically meaningful relationship between crisis episodes and changes in the size/scope of is not immediately apparent.

If there is an economically meaningful relationship to be seen, it will be teased out by (i) controlling for omitted variables that are related to both crisis episodes and changes in government size/scope and/or (ii) weighting crisis episodes in a way more appropriate than the simple dummy variables described above. Along the lines of (ii), our second approach to the measurement of crises is to record the duration (in years) of each crisis. ${ }^{15}$ The duration of a crisis is one dimension of its magnitude and it may be reasonable to assign greater weight to more prolonged crisis episodes. The recorded duration is independent of the panel's time dimension. For example, in the RR data the Central African Republic is coded as experiencing a banking crisis during all years from 1988 to 1999 inclusive. Because of this, 12 years is the recorded banking crisis duration for both our 1986-1990 (5-year panel) and 1981-1990 (10-year panel) observation of the Central African Republic. Duration variables are included in our regressions in place of the basic dummy variables. Note that, since a duration variable only takes a non-zero value when its corresponding dummy variable is non-zero, when the duration variable is included in a regression its coefficient can be interpreted as the interaction between the dummy and duration variables. The following summarizes the variables described thus far and introduces some notation:

\footnotetext{
${ }^{15}$ In addition to including the duration of each type of crisis separately, we also included as sum of the duration of all five types of crisis together as a robustness check (TOTAL_DUR). Significant results from this estimation are given in Table 10; full results are available upon request.
} 
- $B A N K=1$ if a crisis occurred in a given 5-year (10-year) period; 0 otherwise;

- similarly for DEBT_EXT,DEBT_INT, CURRENCY, and INFLATION;

- BANK_DUR = the duration of an observed crisis episode beginning in a given 5year (10-year) period;

- similarly for DEBT_EXT_DUR,DEBT_INT_DUR,CURRENCY_DUR, and INFLATION_DUR;

- $\quad B A N K_{-} D U R>0$ iff $B A N K=1$ so it follows that $B A N K_{-} D U R=$ BANK $\times B A N K \_D U R$;

- similarly for the other categories of crises.

Given that institutions are highly persistent, it may also be the case that we may not see significant changes in them for a large number of years, even more so than our long-run period of 10 years. In addition, this persistence may indicate that it may take several crises, lasting a large number of years, for there to be significant changes. For these reasons, we estimate a single long cross-section regression. To do so, we record the total number of years spent in crisis from 1961-2000. We again pause here to summarize and introduce some notation.

- BANK_CROSS = total number of years spent in a banking crisis from 1961-2000;

- similarly for DEBT_EXT_CROSS,DEBT_INT_CROSS,CURRENCY_CROSS, INFLATION_CROSS.

\section{iii. Other Controls}

As stated above, all of our regressions include the initial size/scope of government as a control. We also include several other controls. Following de Haan et al. (2009) we include a dummy variable that takes a value of 1 if the observation on the dependent value occurs during a period of economic distress. For each country in the sample, we take the entire 1961-2010 real GDP 
series from the PWTs and calculate trend values using a Hodrick-Prescott filter. ${ }^{16}$ For 5 -year (10year) periods we assign the dummy variable a value of 1 if the annual output gap (trend minus actual value) ever became larger than $4 \%$ of actual GDP during that time.

Following Djankov et al. (2008) we also control for foreign aid flows, oil production as a share of GDP, and terms of trade shocks. Djankov et al. argue that both foreign aid flows and geographically agglomerated (point) resources, such as oil, create rent-seeking games that lead to institutional change. Regarding aid, Svensson (2000) finds that aid flows are associated with higher levels of corruption; Rajan and Subramanian (2007) also find that aid is associated with decreased quality of governance. Particularly relevant to this study, Heckelman and Knack (2008) and Young and Sheehan (2013) both report negative effects of aid on the EFW index and component area indices. Similar results are reported for point resources. For example, studies by Isham et al. (2005) find that they are associated with deteriorations in institutional quality and policies. Lastly, Djankov et al. (2008, p. 176) argue that "[s]udden changes in the terms of trade are shocks that can lead to social unrest and political instability." Such unrest and instability can feed into changes in the size/scope of government.

Foreign aid is measured by official development assistance (ODA) flows that are reported for the Development Assistance Committee (DAC) by the OECD. We include ODA flows in the regressions as a share of real GDP. ODA flows are converted into 2005 dollars using the World Import Unit Value index from the IMF.

We obtain data on oil production and prices from the BP Statistical Review of World Energy, Historical Data. Oil production is reported in barrels and oil prices are given in 2009 dollars which we subsequently converted into 2005 dollars using the World Import Unit Value

\footnotetext{
${ }^{16}$ The smoothing parameter for the HP filter is assigned a value of 6.25 , typical for applications using annual data.
} 
index. We use oil share in our analysis which is calculated by multiplying oil production with oil prices and taking that product as a share of a country's real GDP.

As terms of trade shock measures, we separately take the average values of negative and positive growth rates of the terms of trade over the relevant time periods. Considering positive and negative shocks separately acknowledges that their effects on political stability may be asymmetric. The data we use are values of the World Bank's Net Barter Terms of Trade Index which measures the percent ratio of an export unit value index over an import value index. ${ }^{17}$

In addition, we control for the number of intra-state conflicts present in the relevant time period. These intra-state conflicts have been argued to be both a source of institutional change and a cause of institutional persistency. For example, Roland (2004) argues that, although institutional change is often the object of intra-state conflicts, these conflicts may make it more difficult for agents to overcome the collective action problems that stand in the way of institutional change. In addition, Acemoglu (2003) argues that "theories of social conflict" are most appropriate in analyzing institutional change. In these theories, institutions are seen as the result of politically powerful groups that attempt to maximize their own welfare, rather than that of the society in which they live. Thus, in either case, we can see that intra-state conflict is likely to be important to control for when examining institutional change.

Lastly, we control for country-level and period fixed effects. Each of these additional controls - call them, respectively, GAP, ODA,OIL, POS_SHOCKS, NEG_SHOCKS, and CONFLICT - are recorded for the time period over which we observe a change in the size/scope of government. For example, if our dependent variable is $G / G D P$ during 1970-1980 then $O D A$

\footnotetext{
${ }^{17}$ The base year for this index is 2000 rather than 2005 which is the case for, e.g., the real GDP values that we use. However, since we are taking averages of growth rates the different base year is, in this case, not important.
} 
would be the average foreign aid share of GDP during those same years, 1970-1980. These controls are referred to as the basic controls.

For both the 5-year and 10-year horizons, respectively, it is possible that we may not be seeing statistically significant or economically meaningful results because we are not controlling for a country's overall level of GDP. When discussing the ratchet hypothesis, Higgs (1987) is mainly referring to crisis situations occurring in the United States. In a country like the U.S., with a relatively high level of per-capita GDP, the government is able make these government increasing reforms. However, in a country with a lower level of GDP per-capita, such as the countries discussed in the Pitlik and Wirth (2003) analysis, we may see that the reforms taking place after a crisis are more liberalizing and reduce the overall size and scope of government. Consequently, it may be the case that the effect a crisis has on institutional change is dependent on the level of GDP per-capita in a country. Thus, we re-estimate the above relationships using an interaction between the World Penn Tables' initial (log) level of GDP per-capita and the crisis dummy. This will give us some indication of whether the effect of the crisis is contingent upon the level of GDP per-capita in the country.

In brief, descriptions and sources of all variables are reported in table 1; in the cases where they are meaningful, summary statistics for the variables are reported there as well. The mean values for the basic crisis dummy variables can be interpreted as the share of observations where a crisis is recorded. Currency crises are by far the most prevalent type of crisis in our sample and occur in about $38 \%$ of the 5 -year observations and nearly $60 \%$ of the 10 -year observations. Alternatively, internal sovereign debt crises are the rarest type of crisis, being observed in only about $4 \%$ of 5 -year observations and under $7 \%$ of 10 -year observations. External sovereign debt crisis are more than twice as common in the sample as their internal 
counterparts. We also note here that in terms of the PROPERTY, TRADE, and REGULATION indices, a decent mnemonic is that these all have mean values around 6 and standard deviations around $2 .{ }^{18}$

\section{iv. Instrumental Variables}

Given that we are including the initial level of government size/scope as an explanatory variable, in addition to the likely presence of unobserved country-level fixed effects, the OLS estimates likely suffer from dynamic panel bias (Nickell, 1981). Thus, we employ the system GMM estimation procedure as suggested in Arellano and Bover (1995) and Blundell and Bond(1998). ${ }^{19}$ The system GMM estimator uses both first-differenced and level equations to estimate the coefficients with the assumption that the first-differenced instrumental variables are not correlated with the unobserved fixed effects in the model. System GMM is used as opposed to the difference GMM estimator (Arellano and Bond, 1991) because panel data with an extremely persistent process, such as the case with institutions, is likely going to cause the firstdifferenced estimator with weak instruments to suffer from large finite-sample biases (Blundell and Bond, 1998).

In addition to including the lagged levels and lagged first-differences of the endogenous variables as instruments, we will also include four variables common in the institutional change literature (e.g., Djankov, 2008; Heckelman and Knack, 2008; Young and Sheehan, 2014). These variables include the lagged (log) level of GDP per-capita $(G D P)$, lagged value added of

\footnotetext{
${ }^{18}$ Note, however, that REGULATION has a bit less variation than the other two indices; its sample standard deviation is about 1.375. Despite this, mean of 6; standard deviation of 2 is easy to keep in mind and will not lead one to far quantitatively astray.

${ }^{19}$ Estimates are obtained using the Stata program xtabond2 as developed by David Roodman and described in Roodman (2009).
} 
agriculture as a share of GDP (AGRICULTURE), lagged life expectancy at birth (LIFE_EXPECTANCY), and the infant mortality rate (INFANT_MORT).

While these instruments are likely to be correlated with the levels of institutional quality, it is unlikely that these instruments are correlated with any changes in institutional quality. For example, a higher share of GDP attributed to agriculture is likely going to be correlated with economic crises as some researchers argue that agriculture is an industry that plays a stabilizing role in times of crisis (Goldin and Rezende, 1990). However, it is unlikely that the share of GDP attributed to agriculture is systematically correlated with relatively short-run changes in institutional quality. ${ }^{20}$ Therefore, we argue that these instruments are valid.

\section{Analysis and Results}

Our baseline specification relates changes in the size or scope of government over a 5-year or 10year period to the occurrence of a crisis type during the previous 5-year or 10-year period, as well as the initial size/scope of government:

(1) Government $\mathrm{t}_{\mathrm{i}, \mathrm{t}}-$ Government $\mathrm{i}, \mathrm{t}-\mathrm{l}=\alpha_{0}+\alpha_{1 \mathrm{i}}+\alpha_{2 \mathrm{t}}+\beta_{1}$ Crisis $\mathrm{i}, \mathrm{t}-1_{1}+\beta_{2}$ Government $\mathrm{i}, \mathrm{t}-1+\beta \mathrm{j} X_{\mathrm{i}, \mathrm{t}}+\mathrm{v}_{\mathrm{it}}$ where $i$ indexes countries, $t$ indexes time periods, and $j$ indexes the control variables described above; $\alpha_{1 \mathrm{i}}$ is a country-level fixed effect, $\alpha_{2 \mathrm{t}}$ is a period fixed effect, $X_{\mathrm{i}, \mathrm{t}}$ is a 1 by $\mathrm{j}$ matrix of control variables described above at period $t$ (POS_SHOCKS, NEG_SHOCKS, ODA, OIL, GAP, and CONFLICT), and $v_{i t}$ is an error term. Government corresponds to G/GDP, PROPERTY, TRADE, or REGULATION; Crisis corresponds to BANK,DEBT_EXT, DEBT_INT, CURRENCY, or INFLATION (in the case of the basic crisis dummies). We also report regressions including

\footnotetext{
${ }^{20}$ In the longer run time span, e.g., over 20-30 years, we may see as countries drastically alter their institutions the industrial structure may begin to change.
} 
the crisis duration variables in place of the crisis dummy variables. Recall that including their duration as an alternative regressor can be interpreted as an interaction with the crisis dummy.

When looking at the effects a crisis has on $G / G D P, \beta_{1}<0$ is interpreted as a decrease in the size of government; likewise $\beta_{1}>0$ is interpreted as an increase in the size of government. For a ratchet effect to be present, we would expect $\beta_{1}>0$ when examining the effects of a crisis on the size of government as measured by $G / G D P$. Conversely, when looking at the effects that a crisis has on PROPERTY, TRADE, and REGULATION, $\beta_{1}<0$ is interpreted as an increase in the scope of government, likewise $\beta_{1}>0$ is interpreted as a decrease in the scope of government. For a ratchet effect to be present, we would expect $\beta_{1}<0$ when examining the effects of a crisis on the scope of government as measured by the EFW components. (In other words, while G/GDP is straightforwardly a measure of government size the EFW components measure dimensions of economic freedom and are therefore inverse measures of government scope.)

To be clear about the time structure we provide an example. Bolivia experienced an external sovereign debt crisis that began in 1986; in the five year panel 1986 is part of the 19861990 observation, so DEBT_EXT takes a value of 1 for 1986-1990. Therefore, Bolivia's change in $G / G D P$ from 1990 to 1995 is related to that $1986-1990 D E B T E E X T=1$ value and the initial 1990 value of $G / G D P$. Likewise, in the 10 year panel the analogs are the change in $G / G D P$ from 1990 to 2000, the 1981-1990 value of $D E B T_{-} E X T=1$, and the initial 1990 value of $G / G D P$.

The results tables, while including all controls, show only the effect each crisis variable has on changes in the size and scope for brevity. Full results tables are available in the appendix. Tables 2 and table 3 show a summary of the results of the effect each of the five types of crises have on the change in government size and scope over a 5-year period. We first examine the effect of a crisis in the previous 5-year period on subsequent changes in government using the 
basic crisis dummy (table 2). Second, we examine the effect the duration of the crisis has on subsequent changes in government (table 3). In both cases, all of the coefficient estimates for the lagged government size/scope values are negative, typically well below unity, and significant at the $1 \%$ level. Lagged government size/scope carries most of the relevant information needed to predict its own change over the subsequent 5 years.

Regarding the crisis dummies and durations, statistically significant results are fairly few in number.

- BANK and BANK_DUR have a significant (10\% level and 5\% level, respectively) negative association with $G / G D P$.

- BANK and BANK_DUR have a significant (5\% level and 10\% level, respectively) positive association with PROPERTY.

- BANK has a significant (10\% level) positive association with REGULATION.

- DEBT_EXT and DEBT_EXT_DUR have a significant (10\% level and 5\% level, respectively) positive association with $G / G D P$.

- DEBT_EXT has a significant (5\% level) negative association with PROPERTY.

- DEBT_INT_DUR has a significant (1\% level) negative association with REGULATION.

- CURRENCY_DUR has a significant (10\% level) negative association with $G / G D P$.

The above results seem to suggest that banking and currency crises seem to be decreasing the size and scope of government. Interestingly, the only crisis that has a significant and positive effect on the size of government - such that the size of government increases - is an external sovereign debt crisis; a scenario where the government itself has ostensibly and severely mismanaged its own finances. In addition, only sovereign debt crises (both external and internal) are significantly associated with increases in the scope of government. However, these effects 
are very small. For example, based on the point estimate (0.210) an external debt crisis would have to last for more than 27 years to be associated with a sample standard deviation increase in G/GDP (5.677 percentage points).

Tables 4 and table 5 show the results for the 10 -year horizon. While the statistically significant results for crisis variables are again few and far between, the results are fairly similar to those found in table 2 and table 3, with the exception of currency and banking crises.

- DEBT_EXT and DEBT_EXT_DUR have a significant (5\% level and $10 \%$ level, respectively) positive association with $G / G D P$.

- DEBT_EXT has a significant (10\% level) negative association with PROPERTY.

- CURRENCY has a significant (10\% level) positive association with TRADE and REGULATION.

- CURRENCY_DUR has a significant (5\% level) negative association with $G / G D P$. Thus, we see that all statistically significant effects of banking crises disappear when looking at 10-year intervals. However, currency crises now appear to be decreasing the scope of government. Given that banking and currency crises are often referred to as "twin crises" (e.g., Kaminsky and Rogoff, 1999) it is expected that they would have similar effects.

In addition, the negative effect of CURRENCY_DUR on G/GDP is still present in the 10year period. The point estimate on CURRENCY_DUR is slightly smaller in magnitude than the already small effect reported in table 3 ( -0.064 versus -0.098 ; the latter is only associated with about $2 \%$ of a sample standard deviation increase in $G / G D P$ ). Using the CURRENCY_DUR point estimate in table 4, each additional year of a currency crisis is associated with a 0.064 decrease in $G / G D P$. This implies that a currency crisis would have to last over 15 years to be 
associated with a 1 percentage point increase in a country's $G / G D P$ (and the sample standard deviation of that variable is 5.533 points).

Similar to table 2 and table 3, external debt crises still appear to be increasing both the size and scope of government, although the coefficients for $D E B T_{-} E X T$ are now slightly larger in magnitude. For example, over a 5-year period an external debt crisis explains about a little less than 20 percent of a standard deviation increase in $G / G D P$, while this effect increases to only 21 percent over a 10-year period. Indicating that much of the increase in $G / G D P$ as a result of an external debt crisis occurs in the first five-years after the crisis began.

As mentioned above, the reason we may not be seeing statistically significant or economically meaningful relationships is because the effects of crises may depend on the level of GDP per-capita in the country. Therefore, we estimate

$$
\begin{gathered}
\text { Government }_{\mathrm{i}, \mathrm{t}}-\text { Government }_{\mathrm{i}, \mathrm{t}-1}=\alpha_{0}+\alpha_{1 \mathrm{i}}+\alpha_{2 \mathrm{t}}+\beta_{1} \text { Crisis }_{\mathrm{i}, \mathrm{t}-1}+\beta_{2} \text { Government }_{\mathrm{i}, \mathrm{t}-1}+ \\
\beta_{3} \text { Crisis }_{\mathrm{i}, \mathrm{t}-1} * G D P_{t-1}+\beta_{4} G D P_{\mathrm{i}, \mathrm{t}-1}+\beta \mathrm{j} X_{\mathrm{i}, \mathrm{t}}+\mathrm{v}_{\mathrm{it}}
\end{gathered}
$$

where all is defined as in (1), except there is now the inclusion of an interaction between the basic crisis dummies and the initial level of GDP, in addition to the inclusion of the initial level of GDP as well. If the appearance of a ratchet effect depends on the level of income in the country, then we may expect for $G / G D P, \beta_{3}>0$ and for PROPERTY, TRADE, and REGULATION $\beta_{3}<0$. In these cases given that a crisis occurred in the previous period, a higher level of GDP corresponds to an increase in the size and scope of government. If $\beta_{3}$ is larger in magnitude than $\beta_{1}$, or if we are comparing countries that differ greatly in terms of GDP levels, then we may see an overall increase in the size and scope of government due to a crisis.

Table 6 and table 7 present the results for the 5-year and 10-year periods, respectively, and as before there are very few statistically significant results. However, the 5-year period 
statistically significant results in table $\mathbf{6}$ are largely consistent with the results presented in table 2, with one exception. For the 5-year period we still find that banking crises are largely associated with decreases in the size of government and sovereign external debt crises are associated with increases in the scope of government. However, we now find that inflation crises are associated with increases in the scope of government (TRADE), although these effects are not robust to the specified time period. The 5-year period results presented in table 6 can be summarized as follows.

- $B A N K$ has a significant ( $1 \%$ level) negative association with $G / G D P$ and its interaction has a significant (5\% level) positive association with $G / G D P$.

- DEBT_EXT has a significant (5\% level) negative association with PROPERTY.

- DEBT_EXT has a significant (1\% level) negative association with TRADE and its interaction has a significant (5\% level) negative association with TRADE.

- DEBT_INT interaction has a significant (5\% level) negative association with TRADE.

- CURRENCY interaction has a significant (5\% level) negative association with TRADE.

- INFLATION has a significant (10\% level) negative association with TRADE and its interaction has a significant (5\% level) negative association with $T R A D E$.

A banking crisis in the previous 5-year period is still associated with subsequent decreases in the size of government, however, now the effect is more than 10 times the magnitude it was in table 2. Using the point estimate in table 6, the occurrence of a banking crisis is associated with a decrease in $G / G D P$ of about $10.60 \%$ percentage points, equivalent to an almost 2 standard deviation decrease in $G / G D P$. However, the decrease in $G / G D P$ can be slightly offset with higher $(\log )$ levels of GDP per-capita. Thus, it seems that while banking crises are associated with decreases in the size and scope of government, on average, this effect 
dissipates with increases in GDP per-capita. Furthermore, an external sovereign debt crisis is still associated with increasing the scope of government, only now the significant effect is on both PROPERTY and TRADE (5\% level). In addition, the effect of an external sovereign debt crisis on TRADE actually becomes larger in magnitude at higher $(\log )$ levels of GDP per-capita.

However, there are two major differences between table 2 and table 6. First, is that INFLATION is now associated with increases in the scope of government. As in the case of a sovereign external debt crisis, this effect becomes more severe as GDP per-capita increases. Second, is that both sovereign internal debt crises and currency crises interactions are significantly related to increases in the scope of government. This is indicating that both of these types of crises will likely result in increases in the scope of government in high-income countries. Thus, it does seem that a ratchet effect may be the norm in high-income countries as all crises are associated with increases in the scope of government at higher levels of GDP.

Similarly, for the 10-year period we still find that banking crises are associated with decreases in the scope of government and external sovereign debt and inflation crises are associated with increases in the scope of government.

- $B A N K$ has a significant (10\% level) positive association with TRADE and its interaction has a significant (10\% level) negative association with $T R A D E$.

- DEBT_EXT has a significant (5\% level) negative association with REGULATION and its interaction has a significant ( $5 \%$ level) positive association with REGULATION.

- DEBT_INT has a significant (10\% level) positive association with PROPERTY and its interaction has a significant (10\% level) negative association with PROPERTY.

- INFLATION has a significant (5\% level) negative association with PROPERTY and its interaction has a significant (5\% level) positive association with PROPERTY. 
Interestingly, we now find the effect of a sovereign internal debt crisis is associated with large decreases in the scope of government, even though the results in table 4 provided no such evidence. Thus, this indicates the importance of the initial level of GDP in the determination of the effect a crisis has on government size/scope. Overall the results in table 6 and table 7 reveal two important characteristics in the relationship between crisis and government size/scope. First, in all cases but one, the statistically significant effects of a crisis are either increased in magnitude or at least slightly offset by differences in the (log) level of GDP per-capita. Second, the point estimates are often much larger in magnitude than the basic results presented in table 2 and table 4. Thus, we can see that although a lot of the general (directional) conclusions are the same when comparing the results in table 2 through table 7, including the interaction between the initial level of GDP is important to try to uncover the magnitude of these directional effects and whether these effects are contingent upon being a relatively high (or low) income country.

As mentioned above, given that we have included the initial level of government size/scope and the likely presence of country-fixed effects, the estimates are likely suffering from dynamic panel bias. Therefore, the system GMM estimates of equation (1) are presented for both the 5-year and 10-year horizons in table 8 and table $\mathbf{9}$ in which we treat all explanatory variables as endogenous. The Hansen and Sargan statistics provide no evidence against the null hypothesis that the instruments are valid, though they are not reported as they have been shown to be unreliable in the presence of heteroskedasticity and a large number of instruments, both of which are the case here.

Though there even fewer statistically significant results in table 8 and table 9 overall, a majority of the results that are statistically significant line up with the previous estimates. In every specification the lagged level of government size/scope is statistically significant at the $5 \%$ 
level or lower. Thus, we are still finding that the initial level of institutions carries most of the relevant information needed to explain its change. In addition, at the 5-year horizon both banking crises and external debt crises have effects similar to the previous estimates. Banking crises are significantly (10\% level) associated with subsequent decreases in the scope of crises, while external debt crises are significantly ( $5 \%$ level) associated with subsequent increases in the size of government over a 5-year period.

Furthermore, at the 10-year horizon all significant effects of banking crises disappear as in table 4, while the effects of currency crises become significantly ( $5 \%$ level) related to decreases in the scope of government However, currency crises are now found to be significantly $(10 \%$ level) associated with an increase in the size of government $(G / G D P)$. Although this differs in that the coefficient is statistically significant in table $\mathbf{9}$ and not statistically significant in table 4, it is important to note that the results are not drastically different as both are positively impacting $G / G D P$.

However, there are a few interesting findings that differ from the results presented in table 2 and table 4. We now find that sovereign internal debt crisis tend to decrease the scope of government over the 5-year horizon. Similarly, inflation is also associated with decreases in the scope of government over the 10-year horizon. In both cases, this could be due to the fact that a sovereign internal debt crisis (as opposed to an external debt crisis) and inflation have a direct negative impact on its own citizens, inducing them to demand less government.

Lastly, we explore an even longer-run perspective by reporting regressions of the 19702010 changes in government size/scope variables on the total number of years spent in a given type of economic crisis from 1961-2000. These results are reported in table 10 and all of the regressions also include our full set of controls. Notably, every type of crisis variable is 
significantly and negatively related to a country's score of legal structure and property rights. However, most of the effects are again quite small. For example, the standard deviation of banking crises in our sample is about 2.7 years. Based on the point estimate, and additional 2.7 years spent in a banking crisis during $1961-2000$ is associated with nearly a 0.5 point decrease in PROPERTY. The only case where a sample standard deviation increase in crisis years is associated with more than a 1 point decrease in PROPERTY is that of internal debt crises. The point estimate (-0.621) suggests that a sample standard deviation increase (about 6 years) is associated with about a 3.7 point decrease in PROPERTY, which is a large effect. There are also statistically significant and negative effects on REGULATION associated with DEBT_EXT_CROSS, CURRENCY_CROSS, and INFLATION_CROSS that are all very small.

A plethora of coefficient estimates are reported in tables 2-10 and most of them are statistically insignificant. To give some overall perspective on the results table 11 records, together, only the statistically significant coefficient estimates from all specifications. ${ }^{21}$ One must bear in mind that these estimated effects are small, unless the interaction between initial level of GDP and the crisis is controlled for. However, we find the strongest evidence in support of banking crisis episodes being associated with subsequent market-oriented reforms and a decrease in the size of government. This contrasts to the rather strong evidence that external debt crises are associated with increases in the size and scope of government.

Alternatively, the strongest evidence consistent with government ratchet effects is found in association with a countries' legal structure and property rights scores from the cross section regressions of 40-year changes in government size/scope variables. Spending more years in any type of crisis from 1961-2000 is associated with a country's PROPERTY score declining from

\footnotetext{
${ }^{21}$ This table also includes statistically significant effects of all types of crises together in a single variable (panel f), finding results similar to the results found using the crises separately.
} 
1970-2010. The estimated effects are all small with the notable exception of internal sovereign debt crises. In that case, an additional 6 years spent in internal debt crisis is associated with a drop in PROPERTY of about 3.7 points over 30 years; that is greater than the 2010 spread between the US (7.10) and countries such as Bolivia (3.59), Cote d'Ivoire (4.13), and the Philippines (3.85). There is also evidence that, in the 40-year long-run, external sovereign debt crises, currency crises and inflation crises are associated with increases in government regulation of credit, business and labor.

\section{Conclusions}

Recent responses to the Great Recession (e.g, the US's 2009 American Recovery and Reinvestment Act) have been associated with increases in government expenditures and additional government interventions intended to mitigate the crisis. Are these responses typical? In general, do crises tend to increases in government size and scope?

There seems to be two contrasting answers to this question. One view is that a crisis introduces changes that result in expansions in the size and scope of government that are somewhat irreversible. Therefore, once a crisis has ended the size/scope of government may recede, but will never reach its pre-crisis level (Higgs, 1987). Conversely, another view is that crises actually decrease the size and scope of government. For example, Pitlik and Wirth (2003) explain that deteriorating economic conditions encourage countries to adopt market-oriented policies, resulting in a government that is of smaller size and has less power over the economy.

We expand upon the existing literature by comparing these two views of the effect crises have on government size/scope using five different types of crises: banking crises, currency crises, inflation crises, internal debt crises, external debt crises. We employ the Reinhart and 
Rogoff (2009) data on the five different types of crises to examine the effect crises have on the size/scope of government over both 5-year and 10-year periods, as well as one long-cross section period from 1970-2010. Furthermore, we included additional controls that have been thought to influence a country's institutions and we use two different weighting schemes that are intended to capture the severity and timing of each crisis.

While much of the results are statistically insignificant, we found that over the 5-year and 10-year periods, it appears that banking crises may decrease the size and scope of government suggesting that the second view is more appropriate. On the other hand, external sovereign debt crises appear to increase the size and scope of government, suggesting that the first view is appropriate. In both cases, the magnitude of the statistically significant effects seems to depend on the initial level of GDP per-capita in the country. We note that these results are, in a certain sense, ironic. Even though the public and private sectors are obviously interconnected in ways that make the determination of which is the source of a given crisis difficult, our results suggest that crises manifesting proximately in private financial institutions lead to decreases in the size and scope of government while those manifesting proximately in the sovereigns own finances lead to increases in the size and scope of government.

The Pitlik and Wirth (2003) view is based on an analysis of inflation crises. Inflation episodes are arise proximately from central banking practices, and individuals are likely to lay blame on policymakers. A call for market-oriented reforms in response is, then, intuitively sensible. However, we find no evidence based on inflation crises that is consistent with this view. Again, we report that the response to banking crises appears to be a persistent decrease in the size and scope of government. One possibility is that individuals recognize the extensive involvement in and interconnection with most governments and their countries banking systems. 
Therefore, they perceive banking crises to be rooted in government failure. One interesting avenue for future research is towards a systematic understanding of how individuals perceive the different types of crises in terms of their sources.

Likewise, in the case of external sovereign debt crises it may be the case that individuals perceive the inability of their government to make good on its obligations to foreigners and their governments as the fault of the latter. Conditional on individuals perceiving the crisis to have arisen from external sources, then, their government may act akin to Brennan and Buchanan's (1980) Leviathan, exploiting the opportunity to expand its size and scope. Still, we find no evidence that this leads to a Higgs (1987) type of ratchet where the size and scope expand and then retract, but not to their initial levels. The effects are discernable over the 5-year horizon and then do not appear to weaken over the 10-year horizon.

We also report long-cross section (up to 40-years) results suggest the cumulative frequency of all five types of crises are associated with statistically significant decreases in a country's legal system and property rights, and three out of the five types of crises are associated with statistically significant decreases in a country's regulation score. This suggests that over a significant period of time, a country that spends a larger number of years in crisis will, all else equal, end up having a government with weaker legal systems and property rights and an increased amount of regulations. 


\section{References}

Abiad, A., Detragiache, E., Tressel, T. 2008. A new database of financial reforms. International Acemoglu, D. Why not a political Coase theorem? Social conflict, commitment, and politics.

Alesina, A., Drazen, A. 1991. Why are stabilizations delayed? American Economic Review 81, 1170-1188.

Arellano, M. Bover, O. 1995. Another look at the instrumental variable estimation of errorcomponent models. Journal of Econometrics 68, 29-51.

Arellano, M., Bond, S. 1991. Some tests of specification for panel data: Monte Carlo evidence and an application to employment equations. Review of Economic Studies 58, 277 297.

Baierm S. L., Clance, M., Dwyer, G. P. 2012. Banking Crises and Economic Freedom. in (Gawrtney, Lawson, and Hall, eds.) Economic Freedom of the World: 2012 Annual Report. Vancouver: Fraser Institute.

Blundell, R., Bond, S. 1998. Initial conditions and moment restrictions in dynamic panel data models. Journal of Econometrics 87, 115-143.

Brennan, G., Buchanan, J. M. 1980. The Power to Tax: Analytical Foundations of a Fiscal Constitution. Indianapolis: Liberty Fund.

Brückner, M., Ciccone, A., Tesei, A. 2012. Oil price shocks, income, and democracy. Review

Bruno, M., Easterly, W. 1996. Inflation's children: tales of crises that beget reforms. American

Catão, L., Kapur, S. 2006. Volatility and the debt-intolerance paradox. IMF Staff Papers 53, 195218.

Collier, P., Hoeffler A. 2009. Testing the neocon agenda: democracy in resource-rich 
Dawson, J. W. 2010. Macroeconomic volatility and economic freedom - a preliminary analysis. in(Gwartney, Lawson, and Hall eds.) Economic Freedom of the World: 2010 Annual Report. Vancouver: Fraser Institute.

de Haan, J., Strum, J-E, Zandberg,E. 2009. The impact of financial and economic crises on economic freedom. in(Gwartney and Lawson, eds.) Economic Freedom of the World: 2009 Annual Report. Vancouver: Fraser Institute.

Djankov, S., Montalvo, J. G., Reynal-Querol, M. 2008. The curse of aid. Journal of Economic Growth 13, 169-194.

Drazen, A., Easterly, W. 2001. Do crises induce reform? Simple empirical tests of conventional wisdom. Economics and Politics 13, 129-157.

Drazen, A., Grilli, V. 1993. The benefit of crises for economic reforms. American Economic Review 83, 598-607. Economic Review 86, 213-217.

Goldin, I., Castro de Rezende, G. 1990. Agriculture and Economic Crisis: Lessons from Brazil Organization for Economic Cooperation and Development (OECD).

Gwartney, J., Lawson, R., Hall, J. C. 2010. Economic Freedom of the World: 2010 Annual Report. Vancouver: Fraser Institute.

Harberger, A. 1993. The search for relevance in economics. American Economic Review 83, 117.

Heckelman, J. C., Knack, S. 2008. Foreign Aid and Market-Liberalizing Reform. Economica 75, 524-548.

Heston, A., Summer, R., Aten, B. 2012. Penn World Table Version 7.1. Center for International Comparisons for Production, Income, and Prices at the University of Pennsylvania. 
Higgs, R. 1987. Crisis and Leviathan: Critical Episodes in the Growth of American Government. New York: Oxford University Press.

Higgs, R. 1991. Eighteen problematic propositions in the analysis of the growth of government. Review of Austrian Economics 5, 3-40.

Holcombe, R. G. 1993. Are there ratchets in the growth of federal government spending? Public Finance Review 21, 33-47.

Isham, J., Woodcock, M., Pritchett, L. Busby, G. 2005. The varieties of resource experience: natural resource export structures and the political economy of economic growth. World Bank Economic Review 19, 141-174.

Journal of Comparative Economics 31, 620-652.

Kaminsky, G. L., Reinhart, C. M. 1999. The twin crises: the causes of banking and balance-of payments problems. American Economic Review 89, 473-500.

Lora, E., Olivera, M. 2004. What makes reforms likely: political economy determinants of reforms in Latin America. Journal of Applied Economics 7, 99-135.

Mian, A., Sufi, A., Trebbi, F. 2014. Resolving debt overhang: political constraints in the aftermath of financial crises. American Economic Journal: Macroeconomics 6, 1-28. Monetary Fund (IMF) Working Paper 08/266.

Nickell, S. J. 1981. Biases in dynamic models with fixed effects. Econometrica 49, 1417-1426. of Economics and Statistics 94, 389-399.

Olson, M. 1982. The Rise and Decline of Nations. New Haven: Yale University Press.

Ostry, J., Prati, A., Spilimbergo, A. 2009. Structural reforms and economic performance in advanced and developing economies. International Monetary Fund (IMF) Occasional Paper 268. 
Pitlik, H., Wirth, S. 2003. Do crises promote the extent of liberalization?: An Empirical Test. European Journal of Political Economy 19, 565-581.

Rajan, R., Subramanian, A. 2007. Does aid affect governance? American Economic Review 97, $322-327$

Ramsey, K. W. 2011. Revisiting the resource curse: natural disasters, the price of oil, and democracy. International Organization 65, 507-529.

Reinhart, C. M., Rogoff, K. S. 2008. This time is different: a panoramic view of eight centuries of financial crises. NBER Working Paper 13882.

Reinhart, C. M., Rogoff, K. S. 2009. This Time It is Different: Eight Centuries of Financial Folly. Princeton: Princeton University Press.

Reinhart, C. M., Rogoff, K. S. 2011. From financial crash to debt crisis. American Economic Review 101, 1676-1706.

Rodrick, D. 1996. Understanding economic policy reform. Journal of Economic Literature 34, 941.

Rodrick, D. 1998. Why do more open economies have larger governments? Journal of Political Economy 106, 997-1032.

Roland, G. 2004. Understanding institutional change: fast-moving and slow-moving institutions. Studies in Comparative International Development 38, 109-131.

Ross, M. 2001. Does oil hinder democracy? World Politics 53, 325-361.

Seib, G. F. 2008. In crisis, opportunity for Obama. Wall Street Journal, November 21.

Sobel, R. S., Crowley, G. R. 2012. Do intergovernmental grants create ratchets in state and local taxes. Public Choice (forthcoming). societies. European Economic Review 53, 293-308. 
Svensson, J. 2011. Foreign aid and rent-seeking. Journal of International Economics 52, 437461.

Tsui, K. K. 2010. More oil, less democracy: evidence from worldwide crude oil discoveries. Economic Journal 121, 89-115.

Williamson, J., Haggard., S. 1994. The political conditions for economic reform. In: Williamson, J. (Ed.), The Political Economy of Policy Reform. Washington, DC: Institute for International Economics.

Young, A. T., Sheehan, K. M. 2013. Foreign aid, institutional quality, and growth. Working Paper.

Young, A. T., Sobel, R. S. 2013. Recovery and reinvestment act spending at the state level: Keynesian stimulus or distributive politics? Public Choice 155, 449-468. 
Figure 1. US federal government expenditures as a share of GDP, 1929-2011.

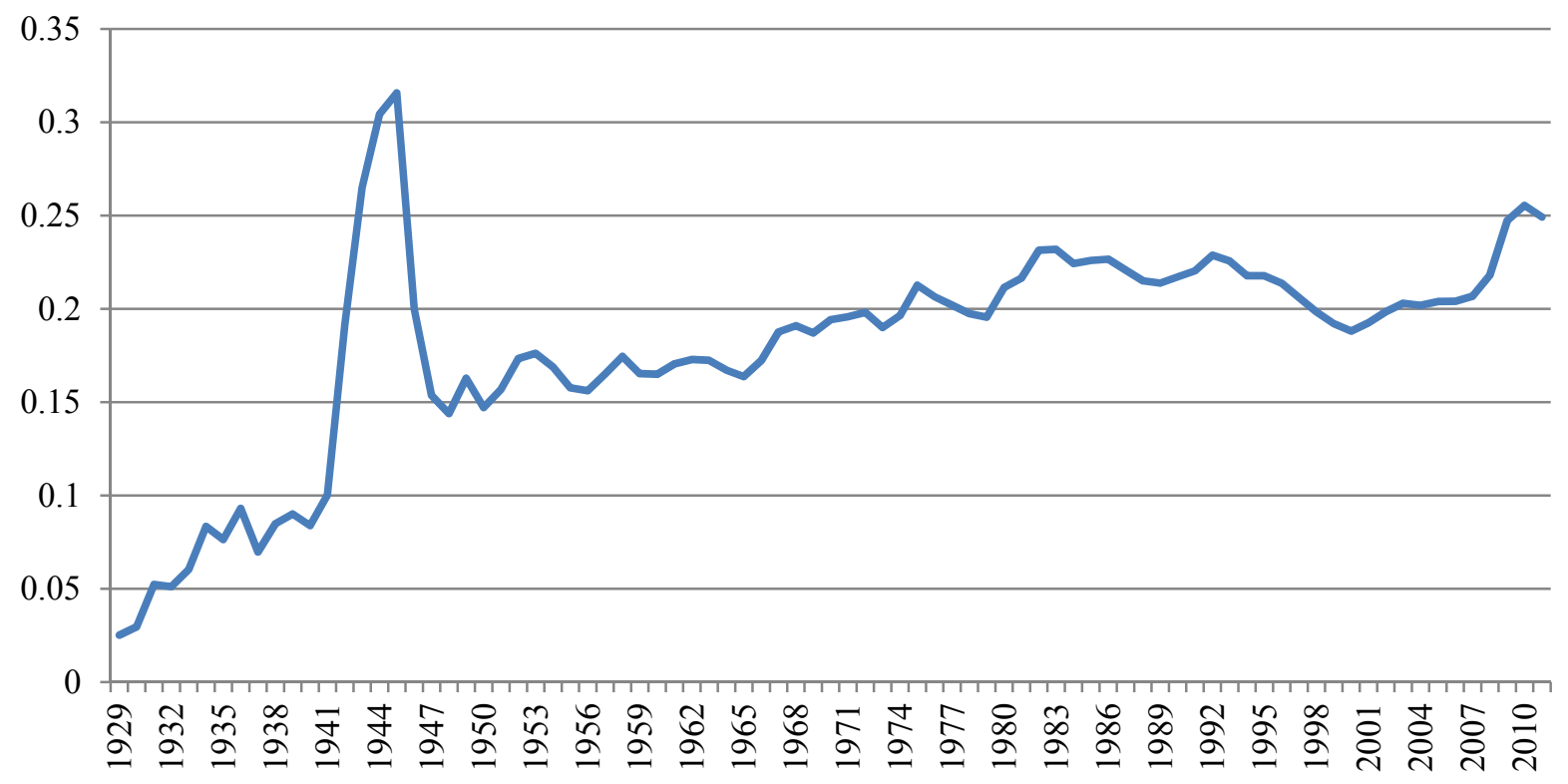

Source: Federal Reserve Economic Data (FRED); federal government current expenditures (billions of dollars, annual, not seasonally adjusted) are divided by gross domestic product (billions of dollars, annual, not seasonally adjusted). 
Figure 2. Changes in countries' GDP government expenditure shares plotted following crisis versus non-crisis time periods.
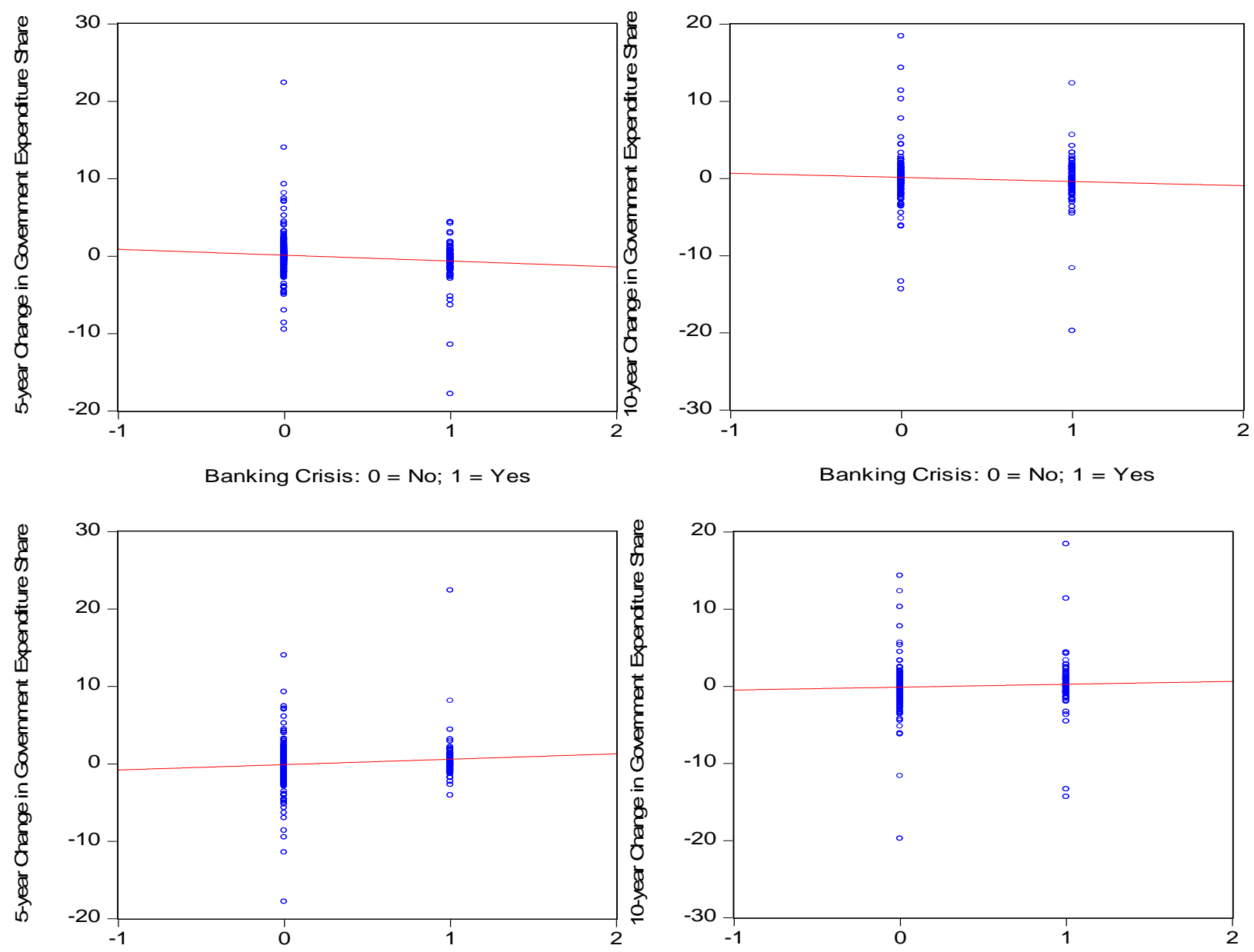

Sovereign Debt Crisis (External): $0=$ No; $1=$ Yes
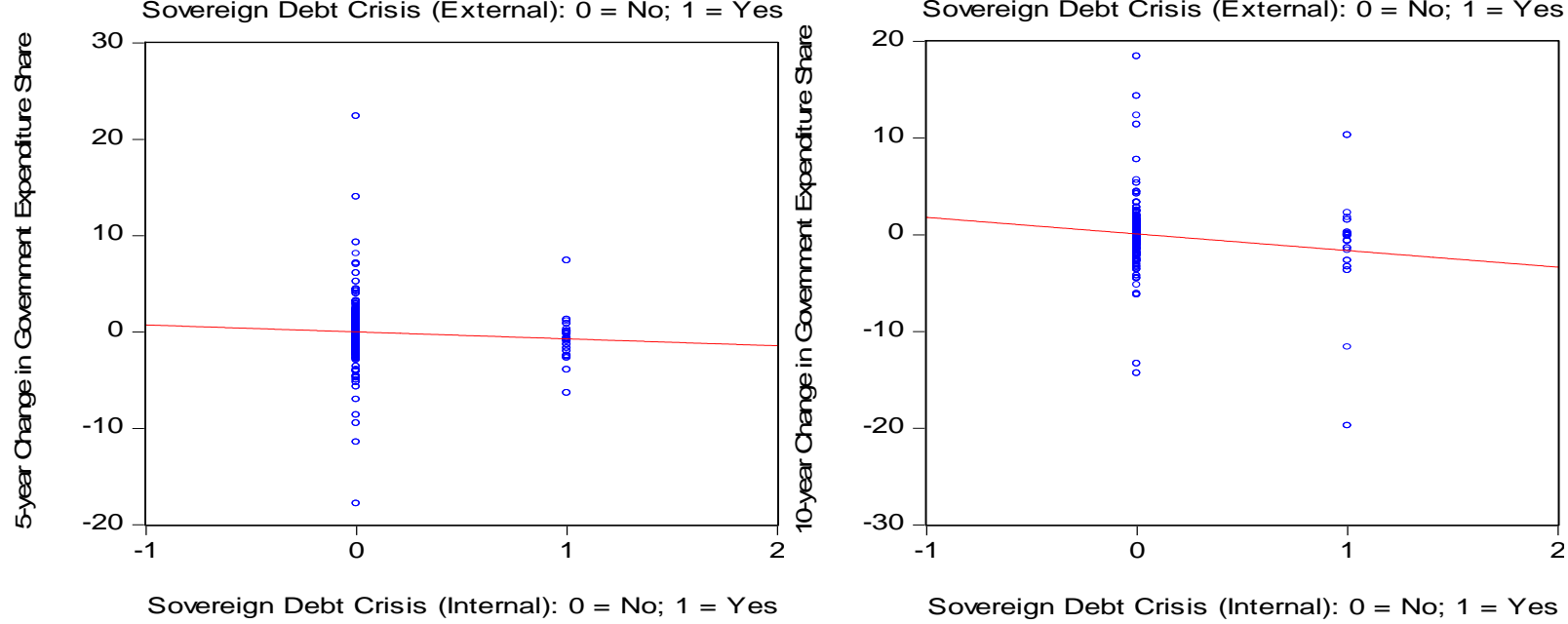

Sources: crisis dates are those used by Reinhart and Rogoff (2011); government expenditure share is the government consumption share of PPP converted GDP per capita at 2005 constant prices (Heston, Summers, and Aten (2012) PWT v. 7.1. OLS regression fit line is included in each graph. Time periods are labeled "crisis" if a Reinhart and Rogoff date occurs within the previous 5- or 10-year period. 
Figure 2. (cont.) Changes in countries' GDP government expenditure shares plotted following crisis versus non-crisis time periods.
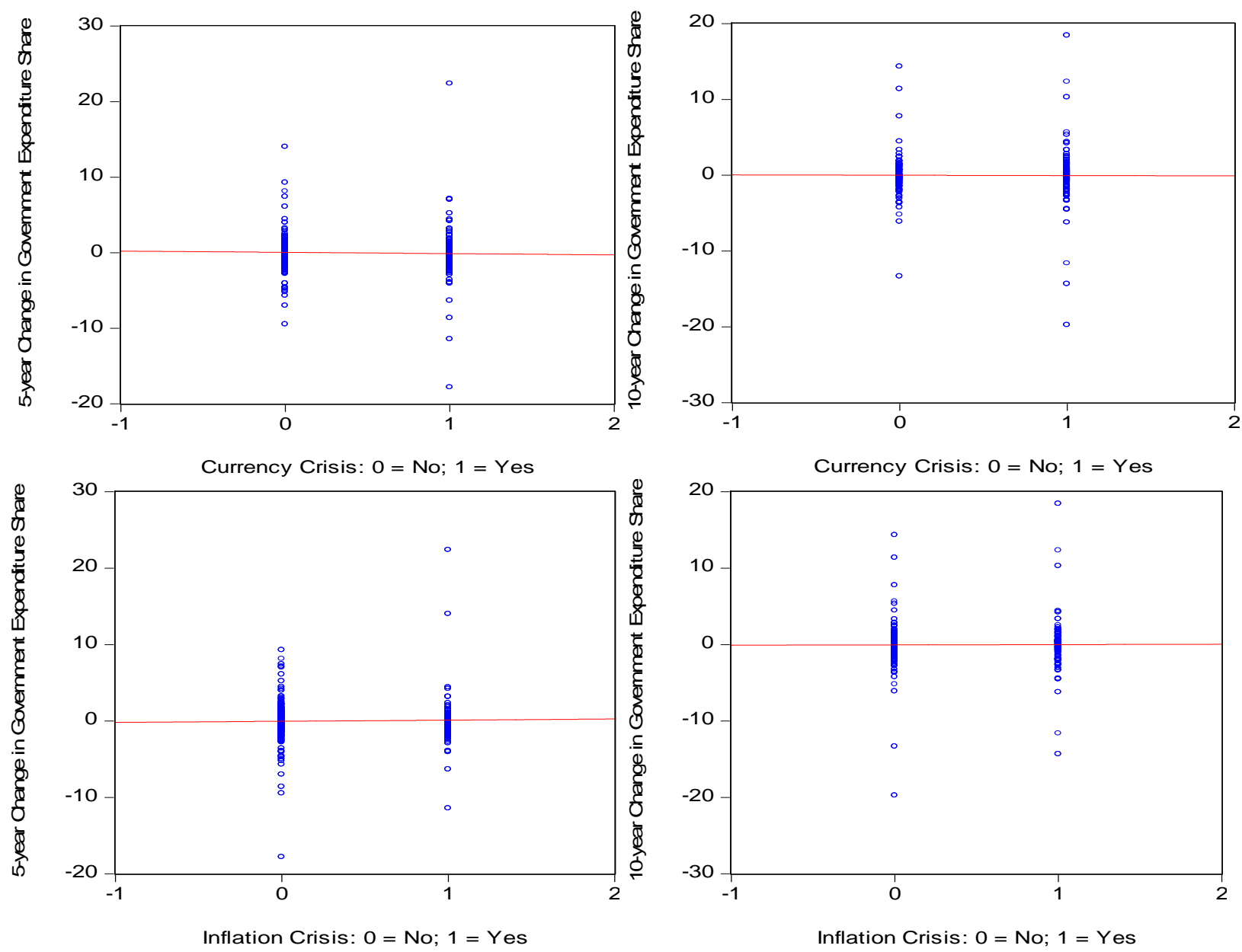

Sources: crisis dates are those used by Reinhart and Rogoff (2011); government expenditure share is the government consumption share of PPP converted GDP per capita at 2005 constant prices (Heston, Summers, and Aten (2012) PWT v. 7.1. OLS regression fit line included in each graph. Time periods are labeled "crisis" if a Reinhart and Rogoff date occurs within the previous 5- or 10-year period. 
Figure 3. Changes in countries' legal system and property rights scores plotted following crisis versus non-crisis time periods.
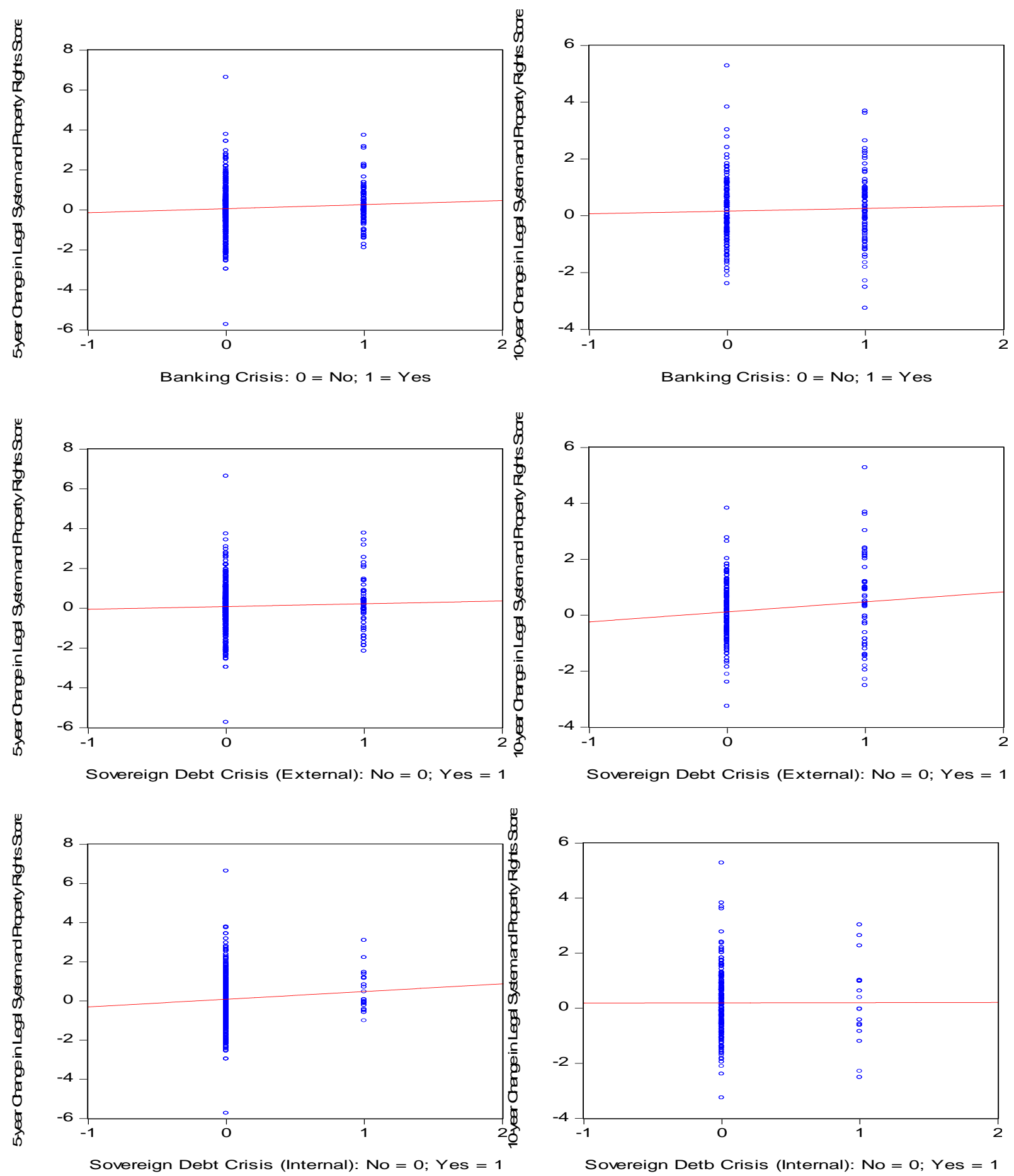

Sources: crisis dates are those used by Reinhart and Rogoff (2011); legal system and property rights score is from the Fraser Institute's Economic Freedom of the World index. OLS regression fit line included in each graph. Time periods are labeled "crisis" if a Reinhart and Rogoff date occurs within the previous 5- or 10-year period. The legal system and property rights score is on a scale of 0 to 10 with the latter representing the strongest rule-of-law and security of property rights. 
Figure 3. (cont.) Changes in countries' legal system and property rights scores plotted following crisis versus non-crisis time periods.
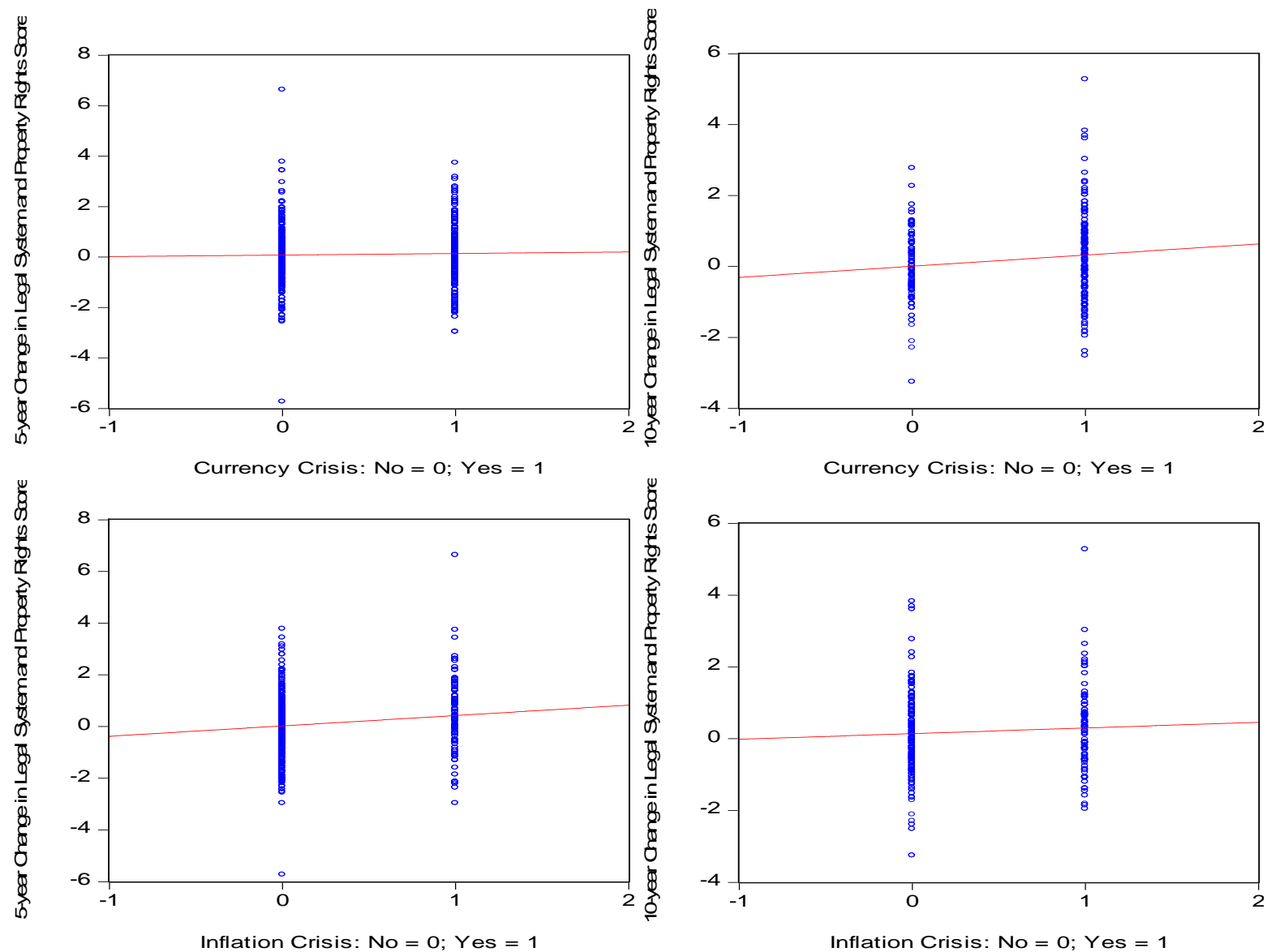

Sources: crisis dates are those used by Reinhart and Rogoff (2011); legal system and property rights score is from the Fraser Institute's Economic Freedom of the World index. OLS regression fit line included in each graph. Time periods are labeled "crisis" if a Reinhart and Rogoff date occurs within the previous 5- or 10-year period. The legal system and property rights score is on a scale of 0 to 10 with the latter representing the strongest rule-of-law and security of property rights. 
Table 1. Descriptions, sources, and summary statistics for variables included in regression analysis.

\begin{tabular}{|c|c|c|c|c|c|c|}
\hline & & & 5-year & & 10-year & \\
\hline Variable & Description & Source & Mean & $\sigma$ & Mean & $\sigma$ \\
\hline G/GDP & government consumption share of GDP & Penn World Tables & 8.902 & 5.677 & 8.857 & 5.533 \\
\hline PROPERTY & legal system and security of property rights score & Gwartney et al. & 5.809 & 2.048 & 5.881 & 2.068 \\
\hline$T R A D E$ & freedom to trade internationally score & Gwartney et al. & 6.176 & 2.369 & 6.184 & 2.355 \\
\hline REGULATION & regulation score & Gwartney et al. & 6.049 & 1.377 & 6.064 & 1.370 \\
\hline$D E B T \_E X T$ & 1 if sovereign debt crisis (external); 0 otherwise & Reinhart \& Rogoff & 0.108 & & 0.200 & \\
\hline$D E B T$ INT & 1 if sovereign debt crisis (internal); 0 otherwise & Reinhart \& Rogoff & 0.040 & & 0.066 & \\
\hline CURRENCY & 1 if currency crisis; 0 otherwise & Reinhart \& Rogoff & 0.378 & & 0.580 & \\
\hline INFLATION & 1 if inflation crisis; 0 otherwise & Reinhart \& Rogoff & 0.189 & & 0.289 & \\
\hline TOTAL & sum of the number of crises in a given period. & Reinhart \& Rogoff & 1.052 & & 1.511 & \\
\hline$B A N K$ DUR & duration (in years) of banking crisis & Reinhart \& Rogoff & 3.750 & 2.661 & 4.027 & 2.690 \\
\hline$D E B T E X T D U R$ & duration (in years) of sovereign debt crisis (ext.) & Reinhart \& Rogoff & 6.662 & 7.007 & 6.743 & 6.909 \\
\hline CURRENCY $\bar{E} \_$DUR & duration (in years) of currency crisis & Reinhart \& Rogoff & 2.496 & 3.484 & 3.089 & 4.040 \\
\hline INFLATION_DUR & duration (in years) of inflation crisis & Reinhart \& Rogoff & 4.378 & 5.426 & 5.406 & 5.979 \\
\hline TOTAL_DUR & sum of the duration (in years) of all crises. & Reinhart \& Rogoff & 3.620 & 7.150 & 7.211 & 10.775 \\
\hline BANK CROSS & total number of years spent in banking crisis & Reinhart \& Rogoff & & & & \\
\hline$D E B T E E X T$ CROSS & total number of years spent in sovereign debt crisis (ext.) & Reinhart \& Rogoff & & & & \\
\hline DEBT_INT_CROSS & total number of years spent in sovereign debt crisis (int.) & Reinhart \& Rogoff & & & & \\
\hline CURRE $\bar{E} N \overline{\bar{Y}}$ CROSS & total number of years spent in currency & Reinhart \& Rogoff & & & & \\
\hline INFLATION_CROSS & total number of years spent in inflation & Reinhart \& Rogoff & & & & \\
\hline TOTAL_CROSSS & total number of years spent in crisis. & Reinhart \& Rogoff & & & & \\
\hline$G A P$ & 1 if real GDP deviation from trend ever $>4 \%$ actual GDP; 0 otherwise & Penn World Tables & & & & \\
\hline$O D A$ & average ratio of real official development assistance to real GDP & OECD; IMF; PWTs & 0.008 & 0.018 & 0.008 & 0.017 \\
\hline OIL & average ratio of real oil production to real GDP & BP; IMF; PWTs & 0.018 & 0.053 & 0.017 & 0.050 \\
\hline POS_SHOCKS & average of positive annual terms of trade growth observations & UN; IMF & 0.080 & 0.083 & 0.084 & 0.074 \\
\hline$N E G S H O C K S$ & average of negative annual terms of trade growth observations & UN; IMF & 0.073 & 0.072 & 0.072 & 0.060 \\
\hline CONFLICT & average number of intra-state conflicts & Dep. of Peace and Conflict Research & 0.270 & 0.752 & 0.258 & 0.739 \\
\hline AGRICULTURE & Value added of agriculture as a share of GDP & World Development Indicators & 13.360 & 11.761 & 13.396 & 11.855 \\
\hline LIFE_EXPECTANCY & Life expectancy at birth, total number of years. & World Development Indicators & 67.878 & 9.723 & 67.828 & 9.913 \\
\hline INFANT $\overline{A N R T}$ & Infant mortality rate, per 1,000 live births. & World Development Indicators & 38.510 & 36.567 & 39.027 & 37.572 \\
\hline
\end{tabular}

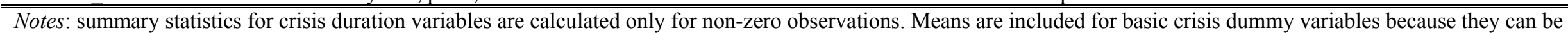
interpreted as the share of observations. 
Table 2: Effects of crises on 5-year changes in government size/scope, 1966-2010; full set of controls included.

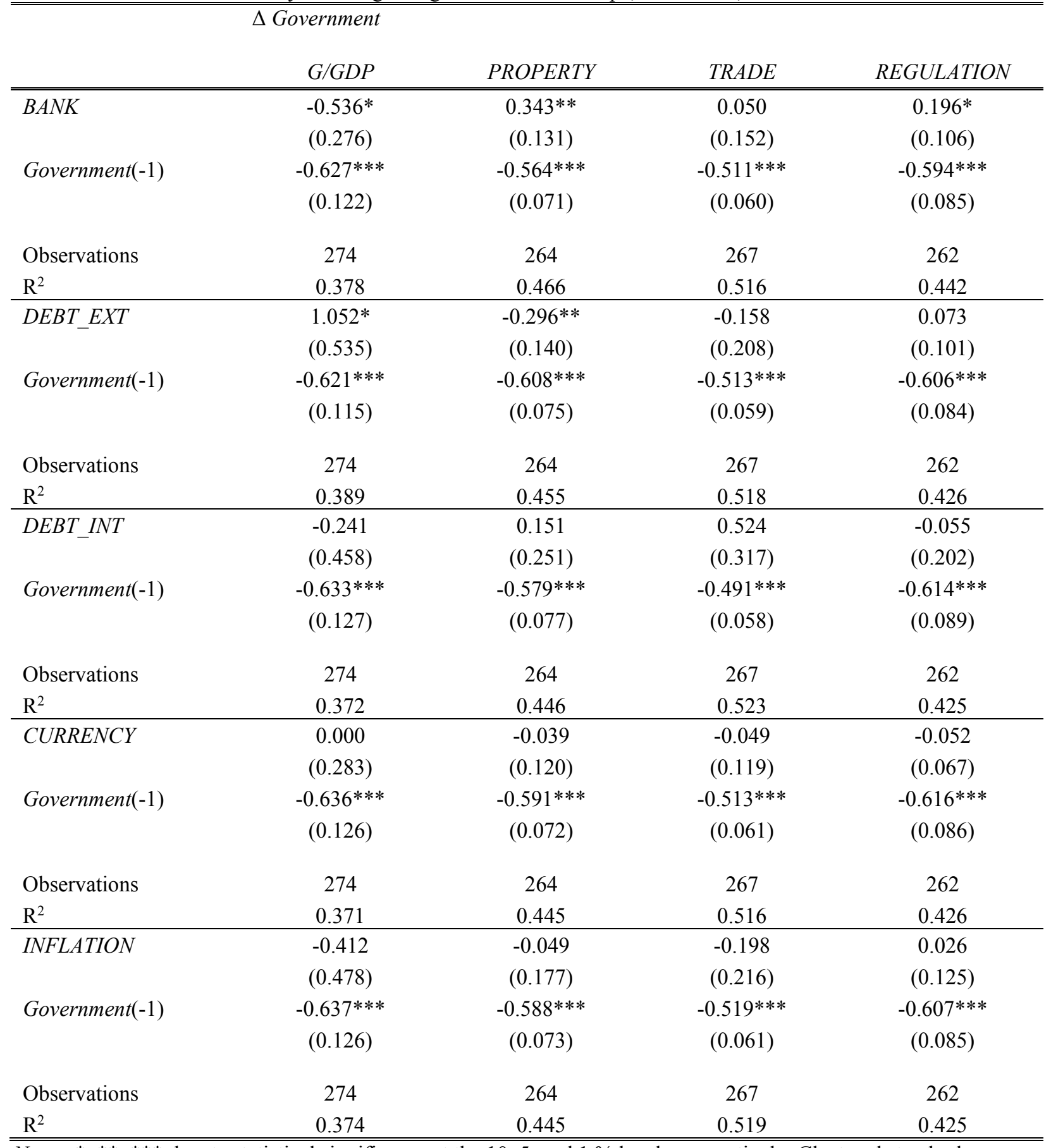

Notes: ${ }^{*}, * *, * *$ denote statistical significance at the 10,5 , and $1 \%$ levels, respectively. Clustered standard errors are in parentheses. Period and country-level fixed effects and a constant are included in all regressions though not reported. 
Table 3: Effects of crisis duration on 5-year changes in government size/scope, 1966-2010; full set of controls included.

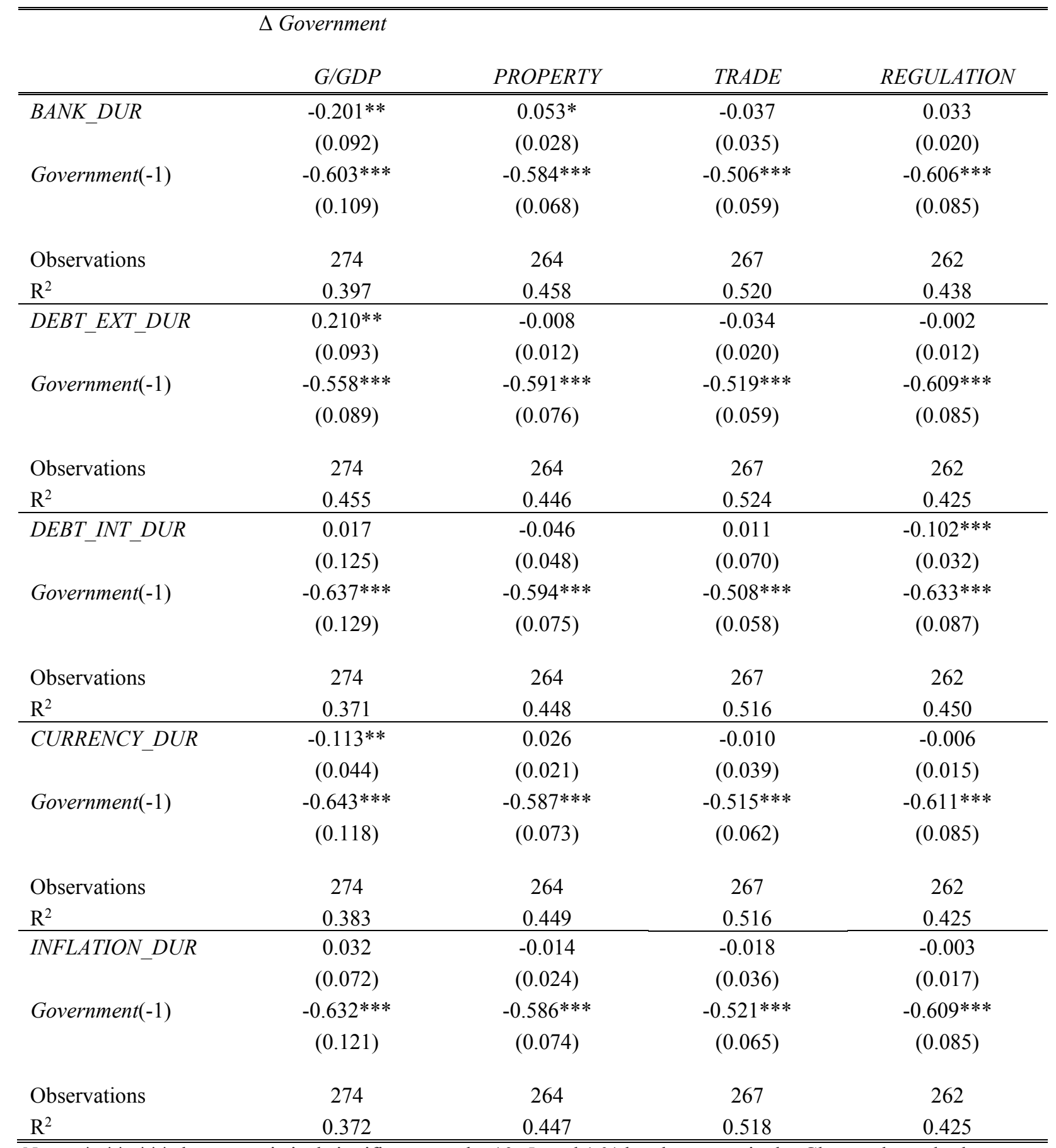

Notes: ${ }^{*}, * * * * *$ denote statistical significance at the 10,5 , and $1 \%$ levels, respectively. Clustered standard errors are in parentheses. Period and country-level fixed effects and a constant are included in all regressions though not reported. 
Table 4: Effects of crises on 10-year changes in government size/scope, 1961-2010; full set of controls included.

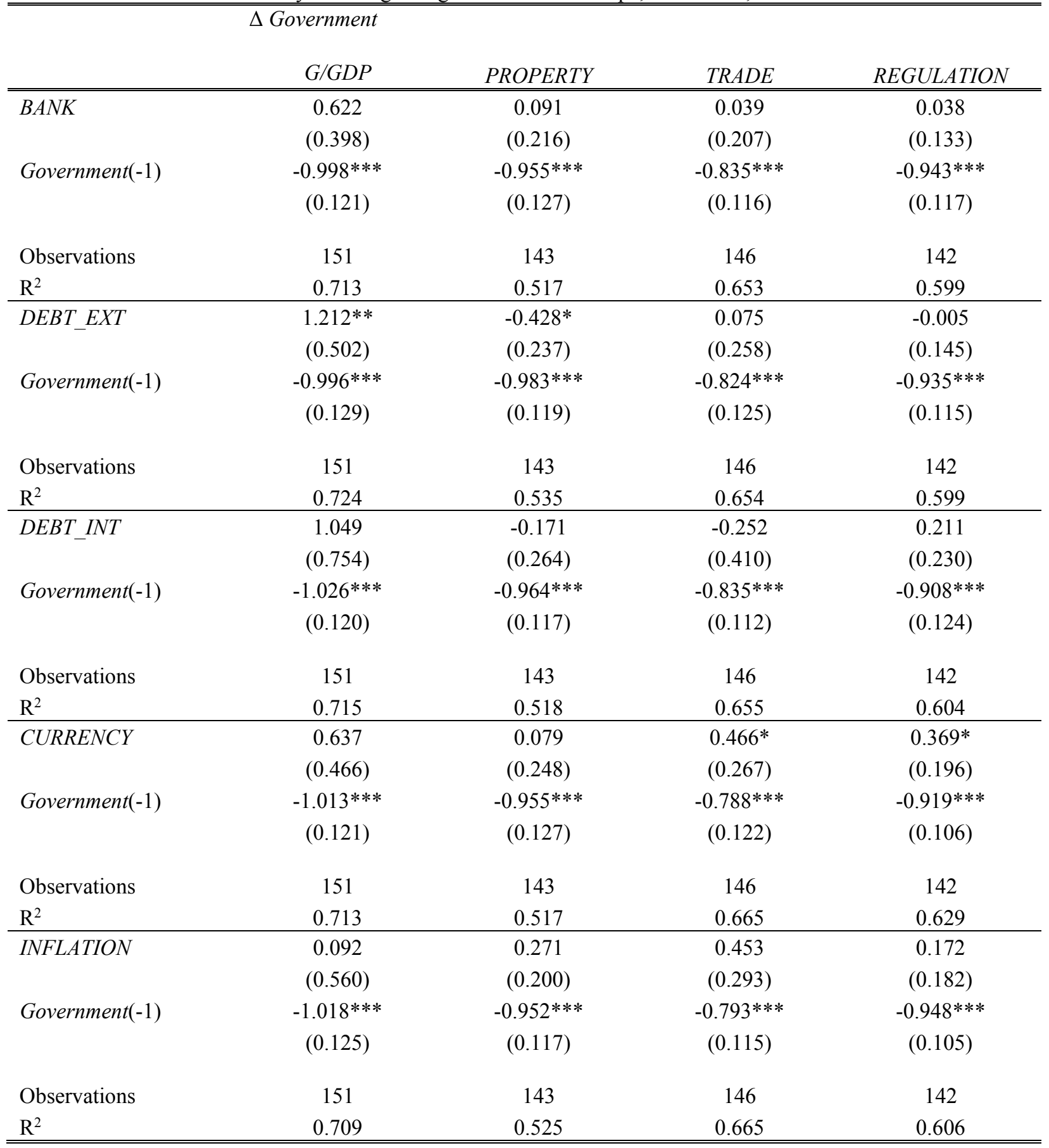

Notes: ${ }^{*}, * *, * *$ denote statistical significance at the 10,5 , and $1 \%$ levels, respectively. Clustered standard errors are in parentheses. Period and country-level fixed effects and a constant are included in all regressions though not reported. 
Table 5: Effects of crisis duration on 10-year changes in government size/scope, 1961-2010; full set of controls included.

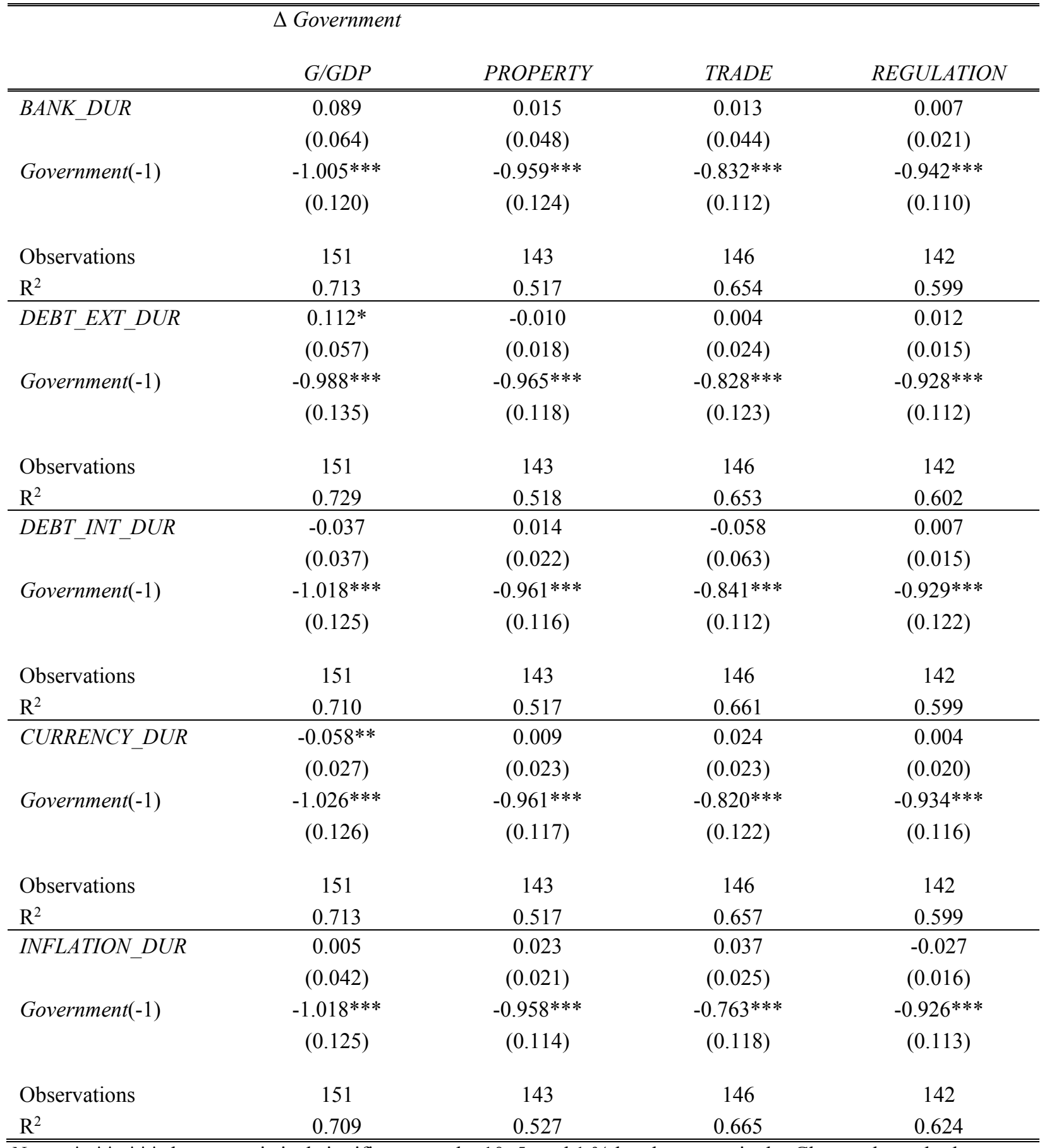

Notes: $*, * *, * * *$ denote statistical significance at the 10,5 , and $1 \%$ levels, respectively. Clustered standard errors are in parentheses. Period and country-level fixed effects and a constant are included in all regressions though not reported. 
Table 6: Effects of crises on 5-year changes in government size/scope, 1966-2010; full set of controls and initial $(\log )$ level of GDP per-capita interaction included.

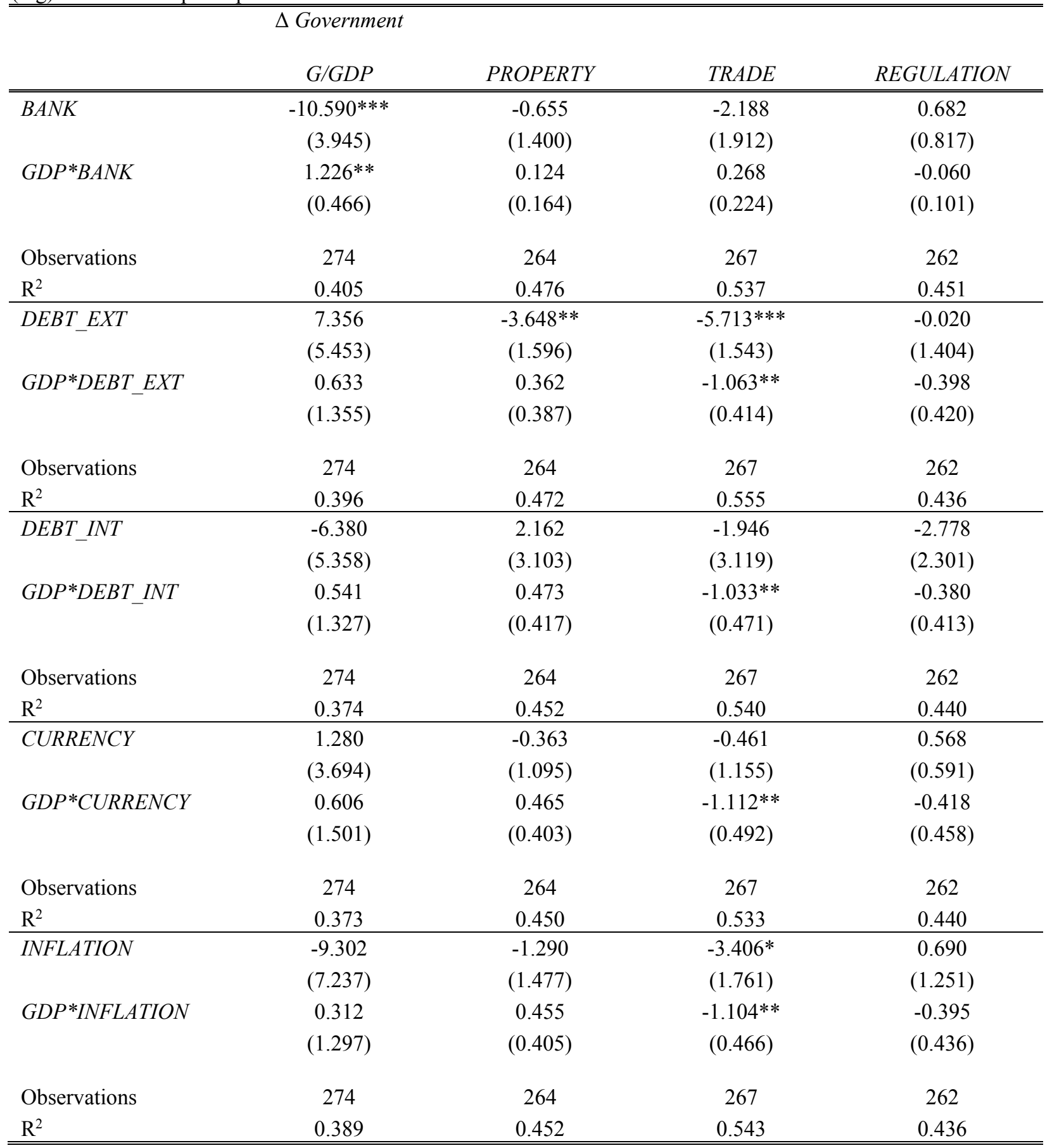

Notes: $*, * *, * * *$ denote statistical significance at the 10,5 , and $1 \%$ levels, respectively. Clustered standard errors are in parentheses. Period and country-level fixed effects and a constant are included in all regressions though not reported. 
Table 7: Effects of crises on 10-year changes in government size/scope, 1961-2010; full set of controls and initial $(\log )$ level of GDP per-capita interaction included.

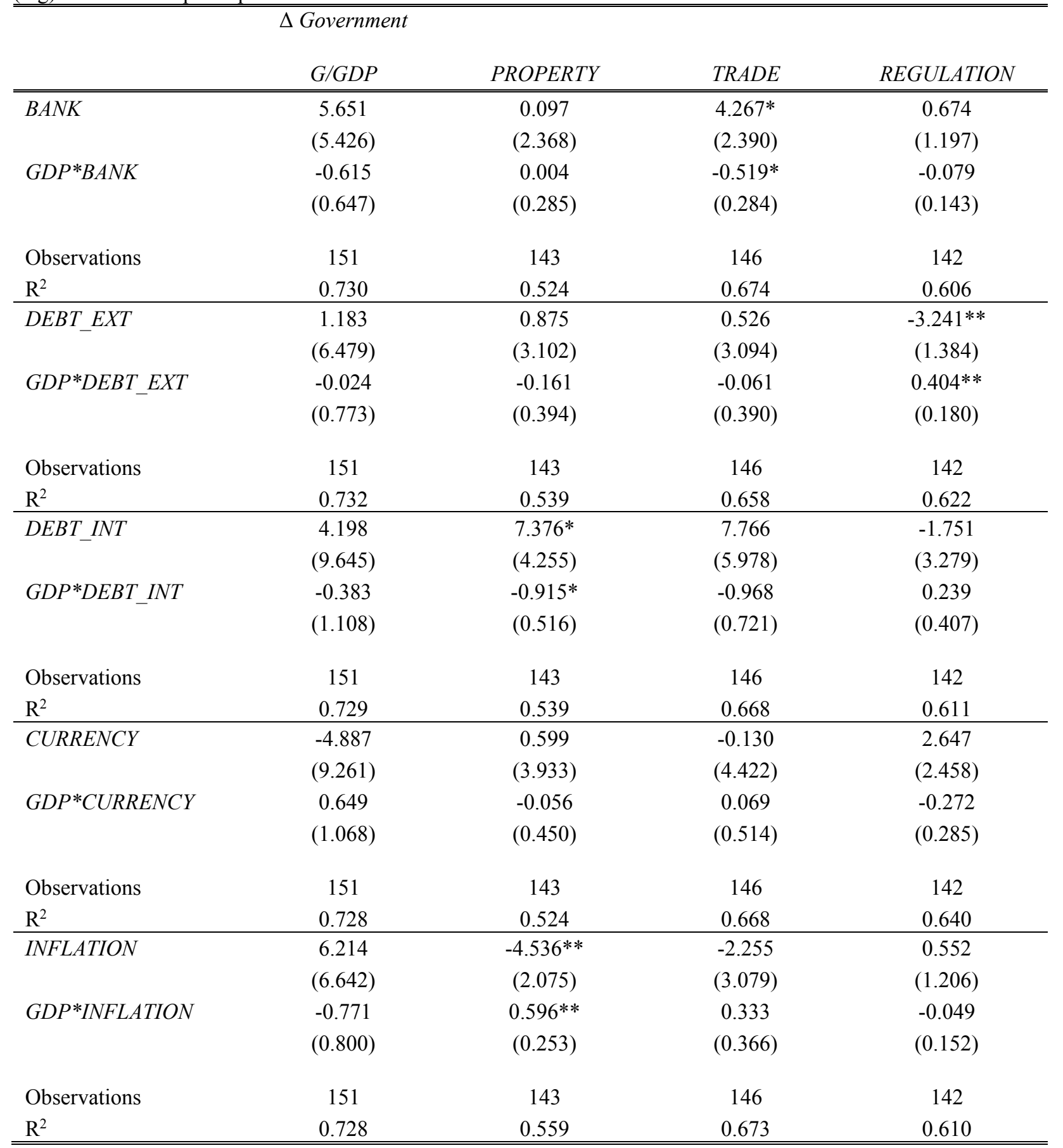

Notes: ${ }^{*}, * *, * * *$ denote statistical significance at the 10,5 , and $1 \%$ levels, respectively. Clustered standard errors are in parentheses. Period and country-level fixed effects and a constant are included in all regressions though not reported. 
Table 8: System GMM effects of crises on 5 year changes in government size/scope, 1966-2010; full set of controls included.

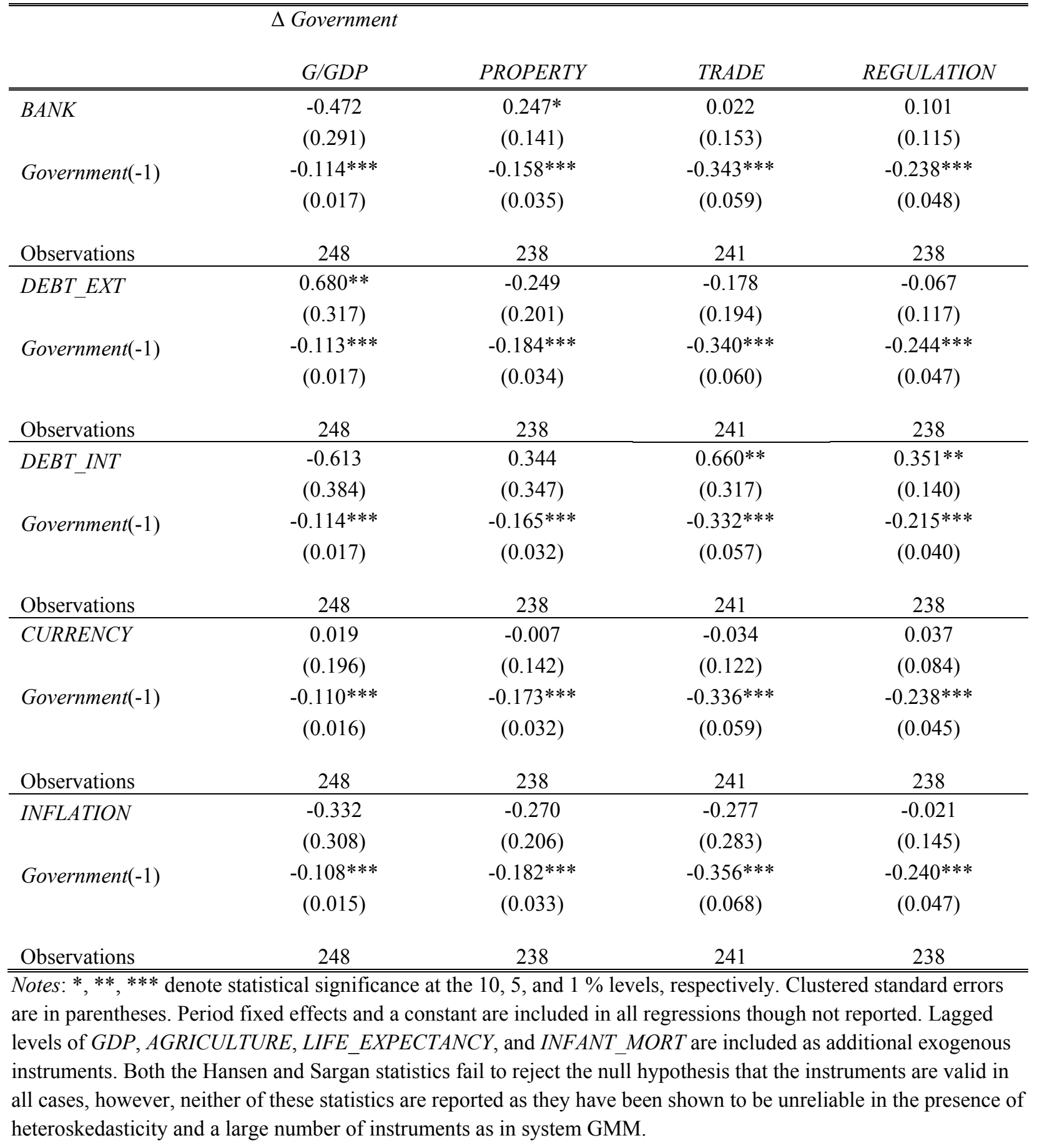


Table 9: System GMM effects of crises on 10 year changes in government size/scope, 1961-2010; full set of controls included.

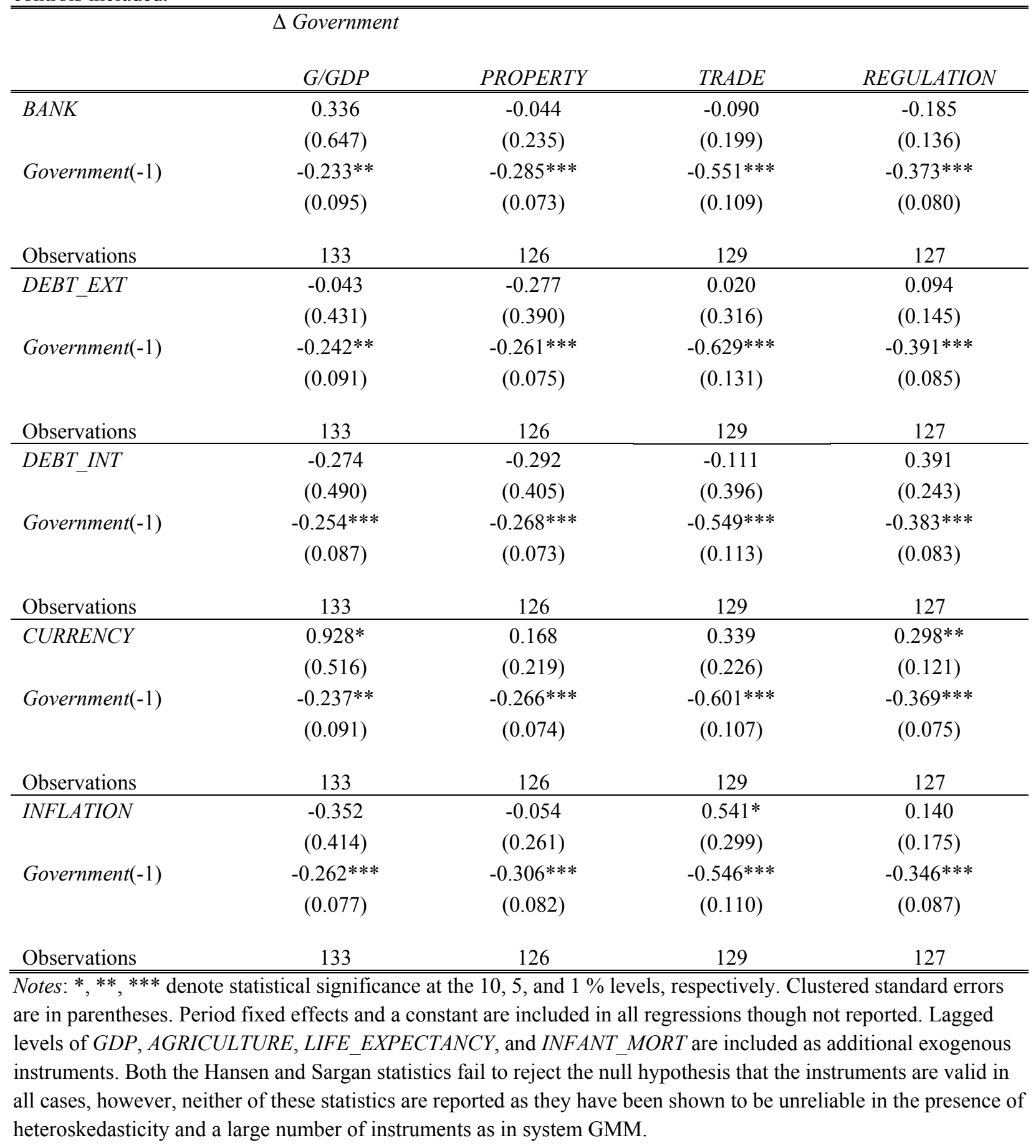


Table 10: Effects of total of total numbers of years spent in crisis from 1961-2000 on the change in government size/scope, 1970-2010; full set of controls included.

\begin{tabular}{|c|c|c|c|c|}
\hline & $\Delta$ Government & & & \\
\hline & $G / G D P$ & PROPERTY & TRADE & REGULATION \\
\hline BANK_CROSS & -0.132 & $-0.169 * * *$ & -0.017 & 0.009 \\
\hline & $(0.145)$ & $(0.053)$ & $(0.034)$ & $(0.036)$ \\
\hline Government(-1) & $-0.576^{* * *}$ & $-0.586^{* * *}$ & $-0.982 * * *$ & $-0.520 * * *$ \\
\hline & $(0.131)$ & $(0.170)$ & $(0.063)$ & $(0.116)$ \\
\hline Observations & 66 & 44 & 53 & 35 \\
\hline $\mathrm{R}^{2}$ & 0.419 & 0.516 & 0.925 & 0.529 \\
\hline DEBT_EXT_CROSS & 0.043 & $-0.107^{*}$ & 0.019 & $-0.096^{*}$ \\
\hline & $(0.091)$ & $(0.061)$ & $(0.022)$ & $(0.051)$ \\
\hline Government(-1) & $-0.582 * * *$ & $-0.695 * * *$ & $-0.978 * * *$ & $-0.619 * * *$ \\
\hline & $(0.137)$ & $(0.211)$ & $(0.066)$ & $(0.108)$ \\
\hline Observations & 66 & 44 & 53 & 35 \\
\hline $\mathrm{R}^{2}$ & 0.410 & 0.474 & 0.926 & 0.620 \\
\hline DEBT_INT_CROSS & 0.060 & $-0.621 * * *$ & -0.008 & -0.338 \\
\hline & $(0.069)$ & $(0.209)$ & $(0.015)$ & $(0.239)$ \\
\hline Government(-1) & $-0.576^{* * *}$ & $-0.628 * * *$ & $-0.986^{* * *}$ & $-0.580 * * *$ \\
\hline & $(0.133)$ & $(0.160)$ & $(0.064)$ & $(0.114)$ \\
\hline Observations & 66 & 44 & 53 & 35 \\
\hline $\mathrm{R}^{2}$ & 0.410 & 0.542 & 0.925 & 0.590 \\
\hline CURRENCY_CROSS & 0.006 & $-0.104 * * *$ & 0.001 & $-0.055 * *$ \\
\hline & $(0.043)$ & $(0.029)$ & $(0.013)$ & $(0.021)$ \\
\hline Government(-1) & $-0.572 * * *$ & $-0.814 * * *$ & $-0.984 * * *$ & $-0.610^{* * *}$ \\
\hline & $(0.131)$ & $(0.179)$ & $(0.066)$ & $(0.108)$ \\
\hline Observations & 66 & 44 & 53 & 35 \\
\hline $\mathrm{R}^{2}$ & 0.407 & 0.551 & 0.925 & 0.625 \\
\hline INFLATION_CROSS & 0.009 & $-0.093 * * *$ & 0.003 & $-0.049 *$ \\
\hline & $(0.043)$ & $(0.030)$ & $(0.013)$ & $(0.026)$ \\
\hline Government(-1) & $-0.570 * * *$ & $-0.805 * * *$ & $-0.981 * * *$ & $-0.601 * * *$ \\
\hline & $(0.130)$ & $(0.189)$ & $(0.066)$ & $(0.120)$ \\
\hline Observations & 66 & 44 & 53 & 35 \\
\hline $\mathrm{R}^{2}$ & 0.407 & 0.533 & 0.925 & 0.601 \\
\hline
\end{tabular}

Notes: ${ }^{*}, *$, and $* * *$ denote statistical significance at the 10,5 , and $1 \%$ levels, respectively. Heteroscedastic robust standard errors are in the parentheses. A constant is included in all regressions though not reported. Full set of controls (see table 1 and appendix) included though not reported. 
Table 11: Summarization of statistically significant crisis coefficient estimates.

\begin{tabular}{|c|c|c|c|c|c|c|c|c|c|c|c|c|c|c|}
\hline & $G$ & $P$ & $T$ & $R$ & & $G$ & $P$ & $T$ & $R$ & & $G$ & $P$ & $T$ & $R$ \\
\hline Panel a: Banking Crisis & & & & & Panel b: External Debt Crisis & & & & & Panel c: Internal Debt Crisis & & & & \\
\hline 5-year horizons & & & & & 5-year horizons & & & & & 5-year horizons & & & & \\
\hline$B A N K$ & -0.536 & 0.343 & & 0.196 & $D E B T_{-} E X T$ & 1.052 & -0.296 & & & $D E B T \_I N T$ & & & & \\
\hline BANK_DUR & -0.201 & 0.053 & & & $D E B T_{-} E X T_{-} D U R$ & 0.21 & & & & $D E B T_{-} I N T \_D U R$ & & & & -0.102 \\
\hline$B A N K$ (with interaction) & -10.59 & & & & DEBT_EXT(with interaction) & & -3.648 & -5.713 & & DEBT_INT(with interaction) & & & & \\
\hline$B A N K * G D P$ & 1.226 & & & & $D E B T_{-} E X T * G D P$ & & & -1.063 & & $D E B T \_I N T * G D P$ & & & -1.033 & \\
\hline BANK (system GMM) & & 0.247 & & & DEBT_EXT (system GMM) & 0.680 & & & & DEBT_INT (system GMM) & & & 0.660 & 0.351 \\
\hline$\underline{10 \text {-year horizons }}$ & & & & & $\underline{10 \text {-year horizons }}$ & & & & & $\underline{10 \text {-year horizons }}$ & & & & \\
\hline$B A N K$ & & & 4.267 & & $D E B T_{-} E X T$ & 1.212 & -0.428 & & & $D E B T_{-} I N T$ & & & & \\
\hline BANK_DUR & & & -0.519 & & DEBT_EXT_DUR & 0.112 & & & & DEBT_INT_DUR & & & & \\
\hline BANK (with interaction) & & & & & $D E B T \_E X T$ (with interaction) & & & & -3.241 & DEBT_INT (with interaction) & & 7.376 & & \\
\hline$B A N K * G D P$ & & & & & $D E B T_{-} E X T * G D P$ & & & & 0.404 & $D E B T_{-} I N T * G D P$ & & -0.915 & & \\
\hline BANK (system GMM) & & & & & BANK (system GMM) & & & & & BANK (system GMM) & & & & \\
\hline $1970-2010$ cross-section & & -0.169 & & & $1970-2010$ cross-section & & -0.107 & & -0.096 & $1970-2010$ cross-section & & -0.621 & & \\
\hline Panel d: Currency Crisis & & & & & Panel e: Inflation Crisis & & & & & Panel $f$ : Total Crisis & & & & \\
\hline$\underline{5 \text {-year horizons }}$ & & & & & $\underline{\text { 5-year horizons }}$ & & & & & $\underline{5 \text {-year horizons }}$ & & & & \\
\hline CURRENCY & & & & & INFLATION & & & & & TOTAL & & & & \\
\hline CURRENCY_DUR & -0.113 & & & & INFLATION_DUR & & & & & TOTAL_DUR & & & & \\
\hline CURRENCY(with interaction) & & & & & INFLATION(with interaction) & & & -3.406 & & TOTAL (with interaction) & & -0.751 & -1.855 & \\
\hline CURRENCY * GDP & & & -1.113 & & INFLATION * GDP & & & -1.104 & & TOTAL * GDP & & 0.094 & 0.216 & \\
\hline CURRENCY (system GMM) & & & & & INFLATION (system GMM) & & & & & TOTAL (system GMM) & & & & \\
\hline$\underline{10 \text {-year horizons }}$ & & & & & $\underline{10 \text {-year horizons }}$ & & & & & $\underline{10 \text {-year horizons }}$ & & & & \\
\hline CURRENCY & & 0.466 & 0.369 & & INFLATION & & & & & TOTAL & 0.533 & & & 0.115 \\
\hline CURRENCY_DUR & -0.058 & & & & INFLATION_DUR & & & & & TOTAL_DUR & & & & \\
\hline CURRENCY (with interaction) & & & & & INFLATION (with interaction) & & -4.536 & & & TOTAL (with interaction) & & & & \\
\hline CURRENCY * GDP & & & & & INFLATION * GDP & & 0.596 & & & TOTAL *GDP & & & & \\
\hline CURRENCY (system GMM) & 0.928 & & & 0.298 & INFLATION (system GMM) & & & 0.541 & & TOTAL (system GMM) & & & & \\
\hline 1970 - 2010 cross-section & & -0.104 & & -0.055 & $1970-2010$ cross-section & & -0.093 & & -0.049 & $1970-2010$ cross-section & & -0.047 & & -0.018 \\
\hline
\end{tabular}

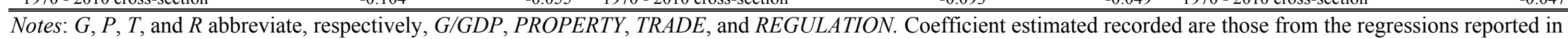

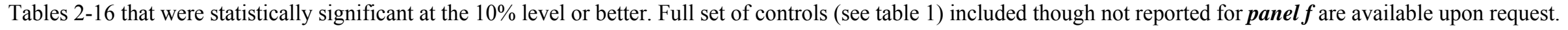




\section{Appendix}

Table A1: Effects of banking crises and their durations on 5-year changes in government size/scope, 1966-2010: full set of controls included. $\Delta$ Government

\begin{tabular}{|c|c|c|c|c|c|c|c|c|}
\hline & \multicolumn{2}{|c|}{$G / G D P$} & \multicolumn{2}{|c|}{ PROPERTY } & \multicolumn{2}{|c|}{ TRADE } & \multicolumn{2}{|c|}{ REGULATION } \\
\hline \multirow[t]{2}{*}{$B A N K$} & $-0.536^{*}$ & & $0.343 * *$ & & 0.050 & & $0.196^{*}$ & \\
\hline & $(0.276)$ & & $(0.131)$ & & $(0.152)$ & & $(0.106)$ & \\
\hline \multirow[t]{2}{*}{$B A N K \_D U R$} & & $-0.201 * *$ & & $0.053^{*}$ & & -0.037 & & 0.033 \\
\hline & & $(0.092)$ & & $(0.028)$ & & $(0.035)$ & & $(0.020)$ \\
\hline \multirow[t]{2}{*}{ Government(-1) } & $-0.627 * * *$ & $-0.603 * * *$ & $-0.564 * * *$ & $-0.584 * * *$ & $-0.511 * * *$ & $-0.506^{* * *}$ & $-0.594 * * *$ & $-0.606 * * *$ \\
\hline & $(0.122)$ & $(0.109)$ & $(0.071)$ & $(0.068)$ & $(0.060)$ & $(0.059)$ & $(0.085)$ & $(0.085)$ \\
\hline \multirow[t]{2}{*}{ POS_SHOCKS } & -1.769 & -1.566 & 0.033 & -0.005 & $2.920 * *$ & $2.967 * *$ & 0.486 & 0.459 \\
\hline & $(2.538)$ & $(2.455)$ & $(0.863)$ & $(0.855)$ & $(1.258)$ & $(1.266)$ & $(0.526)$ & $(0.540)$ \\
\hline \multirow[t]{2}{*}{$N E G \_S H O C K S$} & 4.125 & 3.653 & 0.635 & 0.595 & -0.736 & -0.883 & $-1.734 * * *$ & $-1.753 * * *$ \\
\hline & $(2.562)$ & $(2.618)$ & $(1.557)$ & $(1.568)$ & $(1.850)$ & $(1.799)$ & $(0.595)$ & $(0.590)$ \\
\hline \multirow[t]{2}{*}{$O D A$} & -34.904 & -33.258 & 4.441 & 4.678 & 11.207 & 12.004 & 6.174 & 6.301 \\
\hline & $(49.693)$ & $(47.278)$ & $(4.742)$ & $(4.725)$ & $(8.056)$ & $(7.876)$ & $(5.903)$ & $(6.041)$ \\
\hline \multirow[t]{2}{*}{$O I L$} & $-20.439 * *$ & $-19.332 * *$ & 0.601 & -0.279 & -8.789 & -8.718 & 0.477 & 0.061 \\
\hline & $(8.813)$ & $(8.659)$ & $(3.770)$ & $(4.022)$ & $(5.688)$ & $(5.446)$ & $(2.358)$ & $(2.404)$ \\
\hline \multirow[t]{2}{*}{$G A P$} & $0.501 * *$ & 0.368 & -0.074 & -0.068 & $-0.275^{*}$ & $-0.305^{*}$ & -0.179 & -0.167 \\
\hline & $(0.249)$ & $(0.242)$ & $(0.141)$ & $(0.142)$ & $(0.164)$ & $(0.161)$ & $(0.108)$ & $(0.105)$ \\
\hline \multirow[t]{2}{*}{ CONFLICT } & 1.150 & 1.216 & -0.138 & -0.152 & 0.134 & 0.165 & -0.106 & -0.112 \\
\hline & $(0.755)$ & $(0.742)$ & $(0.266)$ & $(0.271)$ & $(0.182)$ & $(0.182)$ & $(0.117)$ & $(0.118)$ \\
\hline Observations & 274 & 274 & 264 & 264 & 267 & 267 & 262 & 262 \\
\hline $\mathrm{R}^{2}$ & 0.378 & 0.397 & 0.466 & 0.458 & 0.516 & 0.520 & 0.442 & 0.438 \\
\hline
\end{tabular}

Notes: $* * *$, and *** denote statistical significance at the 10,5 , and $1 \%$ levels, respectively. Clustered standard errors are in the parentheses. Period and countrylevel fixed effects and a constant are included in all regressions though not reported. 
Table A2: Effects of external sovereign debt crises and their durations on 5-year changes in government size/scope, 1966-2010: full set of controls included.

$$
\Delta \text { Government }
$$

\begin{tabular}{|c|c|c|c|c|c|c|c|c|}
\hline & \multicolumn{2}{|c|}{$G / G D P$} & \multicolumn{2}{|c|}{ PROPERTY } & \multicolumn{2}{|c|}{ TRADE } & \multicolumn{2}{|c|}{ REGULATION } \\
\hline \multirow[t]{2}{*}{$D E B T \_E X T$} & $1.052 *$ & & $-0.296 * *$ & & -0.158 & & 0.073 & \\
\hline & $(0.535)$ & & $(0.140)$ & & $(0.208)$ & & $(0.101)$ & \\
\hline \multirow[t]{2}{*}{$D E B T_{-} E X T_{-} D U R$} & & $0.210 * *$ & & -0.008 & & -0.034 & & -0.002 \\
\hline & & $(0.093)$ & & $(0.012)$ & & $(0.020)$ & & $(0.012)$ \\
\hline \multirow[t]{2}{*}{ Government(-1) } & $-0.621 * * *$ & $-0.558 * * *$ & $-0.608 * * *$ & $-0.591 * * *$ & $-0.513 * * *$ & $-0.519^{* * *}$ & $-0.606 * * *$ & $-0.609^{* * *}$ \\
\hline & $(0.115)$ & $(0.089)$ & $(0.075)$ & $(0.076)$ & $(0.059)$ & $(0.059)$ & $(0.084)$ & $(0.085)$ \\
\hline \multirow[t]{2}{*}{ POS_SHOCKS } & -1.245 & -1.853 & -0.198 & -0.003 & $2.810^{* *}$ & $2.795^{* *}$ & 0.525 & 0.482 \\
\hline & $(2.642)$ & $(2.456)$ & $(0.887)$ & $(0.873)$ & $(1.288)$ & $(1.290)$ & $(0.538)$ & $(0.545)$ \\
\hline \multirow[t]{2}{*}{$N E G \_S H O C K S$} & 3.087 & 1.906 & 0.756 & 0.473 & -0.550 & -0.324 & $-1.967 * * *$ & $-1.858 * * *$ \\
\hline & $(2.700)$ & $(2.836)$ & $(1.523)$ & $(1.521)$ & $(1.828)$ & (1.843) & $(0.593)$ & $(0.590)$ \\
\hline \multirow[t]{2}{*}{$O D A$} & -33.391 & -26.663 & 3.928 & 4.608 & 10.901 & 9.659 & 6.813 & 6.737 \\
\hline & $(48.702)$ & $(40.115)$ & (4.636) & $(4.675)$ & $(7.567)$ & (7.153) & $(6.330)$ & $(6.328)$ \\
\hline \multirow[t]{2}{*}{ OIL } & $-19.210 * *$ & $-15.863 * *$ & -0.563 & -0.217 & -8.935 & -9.035 & 0.256 & 0.186 \\
\hline & $(8.606)$ & $(7.552)$ & (3.780) & (3.658) & $(5.671)$ & $(5.673)$ & $(2.255)$ & $(2.242)$ \\
\hline \multirow[t]{2}{*}{$G A P$} & $0.601 * *$ & $0.618 * *$ & -0.112 & -0.097 & $-0.288^{*}$ & $-0.293 *$ & -0.188 & $-0.193 *$ \\
\hline & $(0.272)$ & $(0.293)$ & $(0.141)$ & $(0.142)$ & $(0.166)$ & $(0.164)$ & $(0.113)$ & $(0.111)$ \\
\hline \multirow[t]{2}{*}{ CONFLICT } & 1.100 & 0.993 & -0.125 & -0.114 & 0.139 & 0.148 & -0.087 & -0.091 \\
\hline & $(0.756)$ & $(0.661)$ & $(0.282)$ & $(0.276)$ & $(0.176)$ & $(0.178)$ & $(0.120)$ & $(0.123)$ \\
\hline Observations & 274 & 274 & 264 & 264 & 267 & 267 & 262 & 262 \\
\hline $\mathrm{R}^{2}$ & 0.389 & 0.455 & 0.455 & 0.446 & 0.518 & 0.524 & 0.426 & 0.425 \\
\hline
\end{tabular}

Notes: ${ }^{* *}$, and $* * *$ denote statistical significance at the 10,5 , and $1 \%$ levels, respectively. Clustered standard errors are in the parentheses. Period and countrylevel fixed effects and a constant are included in all regressions though not reported. 
Table A3: Effects of internal sovereign debt crises and their durations on 5-year changes in government size/scope, 1966-2010: full set of controls included.

\section{$\Delta$ Government}

\begin{tabular}{|c|c|c|c|c|c|c|c|c|}
\hline & \multicolumn{2}{|c|}{$G / G D P$} & \multicolumn{2}{|c|}{ PROPERTY } & \multicolumn{2}{|c|}{$T R A D E$} & \multicolumn{2}{|c|}{ REGULATION } \\
\hline \multirow[t]{2}{*}{$D E B T_{-} I N T$} & -0.241 & & 0.151 & & 0.524 & & -0.055 & \\
\hline & $(0.458)$ & & $(0.251)$ & & $(0.317)$ & & $(0.202)$ & \\
\hline \multirow[t]{2}{*}{$D E B T \_I N T \_D U R$} & & 0.017 & & -0.046 & & 0.011 & & $-0.102 * * *$ \\
\hline & & $(0.125)$ & & $(0.048)$ & & $(0.070)$ & & $(0.032)$ \\
\hline \multirow[t]{2}{*}{ Government(-1) } & $-0.633 * * *$ & $-0.637 * * *$ & $-0.579 * * *$ & $-0.594 * * *$ & $-0.491 * * *$ & $-0.508 * * *$ & $-0.614 * * *$ & $-0.633 * * *$ \\
\hline & $(0.127)$ & $(0.129)$ & $(0.077)$ & $(0.075)$ & $(0.058)$ & $(0.058)$ & $(0.089)$ & $(0.087)$ \\
\hline \multirow[t]{2}{*}{ POS_SHOCKS } & -1.662 & -1.963 & -0.103 & 0.244 & $2.627^{*}$ & $2.867 * *$ & 0.519 & $1.089 * *$ \\
\hline & $(2.456)$ & $(2.448)$ & $(0.930)$ & $(0.905)$ & $(1.342)$ & $(1.340)$ & $(0.518)$ & $(0.449)$ \\
\hline \multirow[t]{2}{*}{$N E G \_S H O C K S$} & 4.436 & $4.481 *$ & 0.425 & 0.285 & -0.607 & -0.731 & $-1.890 * * *$ & $-2.151 * * *$ \\
\hline & $(2.672)$ & $(2.683)$ & (1.537) & (1.549) & $(1.842)$ & $(1.847)$ & $(0.614)$ & $(0.605)$ \\
\hline \multirow[t]{2}{*}{$O D A$} & -36.460 & -36.338 & 5.505 & 5.379 & 11.879 & 11.368 & 6.641 & 6.596 \\
\hline & $(50.380)$ & $(50.249)$ & $(4.346)$ & $(4.257)$ & $(7.973)$ & $(7.894)$ & $(6.206)$ & $(5.923)$ \\
\hline \multirow[t]{2}{*}{ OIL } & $-20.574 * *$ & $-20.509 * *$ & 0.032 & -0.197 & -8.816 & -8.877 & 0.177 & 0.211 \\
\hline & $(8.990)$ & $(9.124)$ & $(3.586)$ & $(3.751)$ & $(5.531)$ & $(5.643)$ & $(2.274)$ & $(2.444)$ \\
\hline \multirow[t]{2}{*}{$G A P$} & $0.534 * *$ & $0.556 * *$ & -0.084 & -0.100 & -0.252 & -0.276 & $-0.194 *$ & $-0.207^{*}$ \\
\hline & $(0.267)$ & $(0.265)$ & $(0.138)$ & $(0.143)$ & $(0.160)$ & $(0.169)$ & $(0.113)$ & $(0.112)$ \\
\hline \multirow[t]{2}{*}{ CONFLICT } & 1.125 & 1.104 & -0.121 & -0.097 & 0.119 & 0.135 & -0.087 & -0.024 \\
\hline & $(0.759)$ & $(0.749)$ & $(0.276)$ & $(0.267)$ & $(0.175)$ & $(0.174)$ & $(0.119)$ & $(0.089)$ \\
\hline Observations & 274 & 274 & 264 & 264 & 267 & 267 & 262 & 262 \\
\hline $\mathrm{R}^{2}$ & 0.372 & 0.371 & 0.446 & 0.448 & 0.523 & 0.516 & 0.425 & 0.450 \\
\hline
\end{tabular}

Notes: * **, and *** denote statistical significance at the 10,5 , and $1 \%$ levels, respectively. Clustered standard errors are in the parentheses. Period and countrylevel fixed effects and a constant are included in all regressions though not reported. 
Table A4: Effects of currency crises and their durations on 5-year changes in government size/scope, 1966-2010: full set of controls included.

$$
\Delta \text { Government }
$$

\begin{tabular}{|c|c|c|c|c|c|c|c|c|}
\hline & \multicolumn{2}{|c|}{$G / G D P$} & \multicolumn{2}{|c|}{ PROPERTY } & \multicolumn{2}{|c|}{ TRADE } & \multicolumn{2}{|c|}{ REGULATION } \\
\hline \multirow[t]{2}{*}{ CURRENCY } & 0.000 & & -0.039 & & -0.049 & & -0.052 & \\
\hline & $(0.283)$ & & $(0.120)$ & & $(0.119)$ & & $(0.067)$ & \\
\hline \multirow[t]{2}{*}{ CURRENCY_DUR } & & $-0.113 * *$ & & 0.026 & & -0.010 & & -0.006 \\
\hline & & $(0.044)$ & & $(0.021)$ & & $(0.039)$ & & $(0.015)$ \\
\hline \multirow[t]{2}{*}{ Government(-1) } & $-0.636^{* * *}$ & $-0.643 * * *$ & $-0.591 * * *$ & $-0.587 * * *$ & $-0.513 * * *$ & $-0.515^{* * *}$ & $-0.616 * * *$ & $-0.611 * * *$ \\
\hline & $(0.126)$ & $(0.118)$ & $(0.072)$ & $(0.073)$ & $(0.061)$ & $(0.062)$ & $(0.086)$ & $(0.085)$ \\
\hline \multirow[t]{2}{*}{ POS_SHOCKS } & -1.846 & -1.948 & -0.040 & 0.059 & $2.901 * *$ & $2.886^{* *}$ & 0.450 & 0.460 \\
\hline & $(2.653)$ & $(2.618)$ & $(0.845)$ & $(0.854)$ & $(1.251)$ & $(1.249)$ & $(0.529)$ & $(0.538)$ \\
\hline \multirow[t]{2}{*}{$N E G \_S H O C K S$} & $4.454 *$ & $4.823^{*}$ & 0.405 & 0.366 & -0.769 & -0.777 & $-1.867 * * *$ & $-1.866 * * *$ \\
\hline & $(2.662)$ & $(2.773)$ & $(1.543)$ & $(1.533)$ & $(1.837)$ & $(1.835)$ & $(0.599)$ & $(0.606)$ \\
\hline \multirow[t]{2}{*}{$O D A$} & -36.288 & -31.447 & 5.376 & 4.016 & 11.443 & 11.795 & 6.850 & 6.999 \\
\hline & $(50.501)$ & $(50.733)$ & $(4.322)$ & $(4.497)$ & $(7.894)$ & $(8.149)$ & $(6.313)$ & $(6.316)$ \\
\hline \multirow[t]{2}{*}{$O I L$} & $-20.539 * *$ & $-22.336 * *$ & -0.218 & 0.707 & -8.878 & -9.129 & 0.127 & -0.010 \\
\hline & $(8.985)$ & $(8.979)$ & $(3.708)$ & $(4.180)$ & $(5.606)$ & $(6.038)$ & $(2.232)$ & $(2.413)$ \\
\hline \multirow[t]{2}{*}{$G A P$} & $0.549 * *$ & $0.513^{*}$ & -0.092 & -0.088 & $-0.281 *$ & $-0.281 *$ & $-0.192 *$ & $-0.192 *$ \\
\hline & $(0.264)$ & $(0.265)$ & $(0.140)$ & $(0.130)$ & $(0.166)$ & $(0.166)$ & $(0.111)$ & $(0.111)$ \\
\hline \multirow[t]{2}{*}{ CONFLICT } & 1.112 & 1.115 & -0.112 & -0.119 & 0.146 & 0.138 & -0.083 & -0.090 \\
\hline & $(0.752)$ & $(0.753)$ & $(0.277)$ & $(0.268)$ & $(0.179)$ & $(0.178)$ & $(0.123)$ & $(0.125)$ \\
\hline Observations & 274 & 274 & 264 & 264 & 267 & 267 & 262 & 262 \\
\hline $\mathrm{R}^{2}$ & 0.371 & 0.383 & 0.445 & 0.449 & 0.516 & 0.516 & 0.426 & 0.425 \\
\hline
\end{tabular}

Notes: $* * *$, and $* * *$ denote statistical significance at the 10,5 , and $1 \%$ levels, respectively. Clustered standard errors are in the parentheses. Period and countrylevel fixed effects and a constant are included in all regressions though not reported. 
Table A5: Effects of inflation crises and their durations on 5-year changes in government size/scope, 1966-2010: full set of controls included.

\section{$\Delta$ Government}

\begin{tabular}{|c|c|c|c|c|c|c|c|c|}
\hline & \multicolumn{2}{|c|}{$G / G D P$} & \multicolumn{2}{|c|}{ PROPERTY } & \multicolumn{2}{|c|}{ TRADE } & \multicolumn{2}{|c|}{ REGULATION } \\
\hline \multirow[t]{2}{*}{ INFLATION } & -0.412 & & -0.049 & & -0.198 & & 0.026 & \\
\hline & $(0.478)$ & & $(0.177)$ & & $(0.216)$ & & $(0.125)$ & \\
\hline \multirow[t]{2}{*}{ INFLATION_DUR } & & 0.032 & & -0.014 & & -0.018 & & -0.003 \\
\hline & & $(0.072)$ & & $(0.024)$ & & $(0.036)$ & & $(0.017)$ \\
\hline \multirow[t]{2}{*}{ Government(-1) } & $-0.637 * * *$ & $-0.632 * * *$ & $-0.588 * * *$ & $-0.586 * * *$ & $-0.519 * * *$ & $-0.521 * * *$ & $-0.607 * * *$ & $-0.609 * * *$ \\
\hline & $(0.126)$ & $(0.121)$ & $(0.073)$ & $(0.074)$ & $(0.061)$ & $(0.065)$ & $(0.085)$ & $(0.085)$ \\
\hline \multirow[t]{2}{*}{ POS_SHOCKS } & -1.590 & -1.982 & 0.008 & 0.020 & $3.034 * *$ & $2.951 * *$ & 0.474 & 0.484 \\
\hline & $(2.553)$ & $(2.492)$ & $(0.878)$ & $(0.850)$ & $(1.234)$ & $(1.249)$ & $(0.567)$ & $(0.546)$ \\
\hline \multirow[t]{2}{*}{$N E G \_S H O C K S$} & 4.321 & 4.180 & 0.381 & 0.494 & -0.897 & -0.697 & $-1.858 * * *$ & $-1.856 * * *$ \\
\hline & $(2.744)$ & $(2.590)$ & $(1.547)$ & $(1.476)$ & $(1.802)$ & $(1.728)$ & $(0.661)$ & $(0.565)$ \\
\hline \multirow[t]{2}{*}{$O D A$} & -38.414 & -34.254 & 5.051 & 4.429 & 10.214 & 10.160 & 6.851 & 6.618 \\
\hline & $(48.840)$ & $(47.007)$ & $(4.092)$ & $(4.452)$ & $(7.454)$ & $(7.594)$ & $(6.427)$ & $(6.403)$ \\
\hline \multirow[t]{2}{*}{ OIL } & $-20.401 * *$ & $-20.076^{* *}$ & -0.067 & -0.358 & -8.513 & -9.077 & 0.164 & 0.145 \\
\hline & $(9.096)$ & $(9.298)$ & $(3.567)$ & $(3.805)$ & (5.309) & $(5.869)$ & $(2.263)$ & $(2.410)$ \\
\hline \multirow[t]{2}{*}{$G A P$} & $0.502 *$ & $0.580 * *$ & -0.096 & -0.101 & $-0.305^{*}$ & $-0.297 *$ & $-0.191 *$ & $-0.194 *$ \\
\hline & $(0.256)$ & $(0.281)$ & $(0.141)$ & $(0.139)$ & $(0.164)$ & $(0.165)$ & $(0.113)$ & $(0.113)$ \\
\hline \multirow[t]{2}{*}{ CONFLICT } & 1.145 & 1.116 & -0.113 & -0.118 & 0.149 & 0.131 & -0.091 & -0.091 \\
\hline & $(0.761)$ & $(0.765)$ & $(0.275)$ & $(0.279)$ & $(0.179)$ & $(0.180)$ & $(0.124)$ & $(0.124)$ \\
\hline Observations & 274 & 274 & 264 & 264 & 267 & 267 & 262 & 262 \\
\hline $\mathrm{R}^{2}$ & 0.374 & 0.372 & 0.445 & 0.447 & 0.519 & 0.518 & 0.425 & 0.425 \\
\hline
\end{tabular}

Notes: $* * *$, and *** denote statistical significance at the 10,5 , and $1 \%$ levels, respectively. Clustered standard errors are in the parentheses. Period and countrylevel fixed effects and a constant are included in all regressions though not reported. 
Table A6. Effects of banking crises and their durations on 10-year changes in government size/scope, 1961-2010: full set of controls included.

$$
\Delta \text { Government }
$$

\begin{tabular}{|c|c|c|c|c|c|c|c|c|}
\hline \multirow{2}{*}{ BANK } & \multicolumn{2}{|c|}{$G / G D P$} & \multicolumn{2}{|c|}{ PROPERTY } & \multicolumn{2}{|c|}{ TRADE } & \multicolumn{2}{|c|}{ REGULATION } \\
\hline & 0.622 & & 0.091 & & 0.039 & & 0.038 & \\
\hline & $(0.398)$ & & $(0.216)$ & & $(0.207)$ & & $(0.133)$ & \\
\hline \multirow[t]{2}{*}{ BANK_DUR } & & 0.089 & & 0.015 & & 0.013 & & 0.007 \\
\hline & & $(0.064)$ & & $(0.048)$ & & $(0.044)$ & & $(0.021)$ \\
\hline \multirow[t]{2}{*}{ Government(-1) } & $-0.998 * * *$ & $-1.005 * * *$ & $-0.955 * * *$ & $-0.959 * * *$ & $-0.835 * * *$ & $-0.832 * * *$ & $-0.943 * * *$ & $-0.942 * * *$ \\
\hline & $(0.121)$ & $(0.120)$ & $(0.127)$ & $(0.124)$ & $(0.116)$ & $(0.112)$ & $(0.117)$ & $(0.110)$ \\
\hline \multirow[t]{2}{*}{ POS_SHOCKS } & -5.352 & -5.787 & -1.515 & -1.544 & 0.274 & 0.327 & 0.149 & 0.138 \\
\hline & $(5.209)$ & (5.392) & $(1.590)$ & $(1.519)$ & $(1.842)$ & $(1.863)$ & $(1.024)$ & $(0.960)$ \\
\hline \multirow[t]{2}{*}{$N E G \_S H O C K S$} & 11.168 & 10.745 & 1.680 & 1.584 & -2.933 & -3.074 & $-3.508 * *$ & $-3.569 * *$ \\
\hline & $(8.517)$ & $(8.503)$ & (3.094) & (3.179) & $(4.881)$ & $(4.884)$ & $(1.683)$ & $(1.741)$ \\
\hline \multirow[t]{2}{*}{$O D A$} & $-162.554 * *$ & $-165.696^{* *}$ & -3.675 & -4.640 & 6.781 & 5.734 & $13.767^{*}$ & 13.178 \\
\hline & $(62.635)$ & $(63.855)$ & (12.921) & (13.116) & (18.869) & (19.751) & $(7.677)$ & $(7.930)$ \\
\hline \multirow[t]{2}{*}{ OIL } & $-39.616 * * *$ & $-39.518 * * *$ & -13.129 & -12.875 & -14.884 & -14.554 & 1.756 & 1.941 \\
\hline & (13.489) & (13.719) & $(9.513)$ & $(9.122)$ & (11.356) & $(10.822)$ & $(6.618)$ & $(6.593)$ \\
\hline \multirow[t]{2}{*}{$G A P$} & 0.794 & 0.795 & $-0.374 *$ & $-0.375^{*}$ & -0.456 & -0.455 & -0.052 & -0.051 \\
\hline & $(0.508)$ & $(0.512)$ & $(0.201)$ & $(0.202)$ & $(0.336)$ & $(0.336)$ & $(0.168)$ & $(0.165)$ \\
\hline \multirow[t]{2}{*}{ CONFLICT } & 1.306 & 1.306 & -0.224 & -0.229 & 0.318 & 0.320 & 0.128 & 0.128 \\
\hline & $(0.831)$ & $(0.845)$ & $(0.467)$ & $(0.465)$ & $(0.282)$ & $(0.279)$ & $(0.103)$ & $(0.102)$ \\
\hline Observations & 151 & 151 & 143 & 143 & 146 & 146 & 142 & 142 \\
\hline $\mathrm{R}^{2}$ & 0.713 & 0.713 & 0.517 & 0.517 & 0.653 & 0.654 & 0.599 & 0.599 \\
\hline
\end{tabular}

Notes: ${ }^{* *}$, and $* * *$ denote statistical significance at the 10,5 , and $1 \%$ levels, respectively. Clustered standard errors are in the parentheses. Period and countrylevel fixed effects and a constant are included in all regressions though not reported. 
Table A7: Effects of external debt crises and their durations on 10-year changes in government size/scope, 1961-2010: full set of controls included.

\begin{tabular}{|c|c|c|c|c|c|c|c|c|}
\hline \multirow{2}{*}{$\overline{\text { DEBT_EXT }}$} & \multicolumn{4}{|c|}{$\Delta$ Government } & \multicolumn{2}{|c|}{$T R A D E$} & \multicolumn{2}{|c|}{ REGULATION } \\
\hline & $\begin{array}{l}1.212 * * \\
(0.502)\end{array}$ & & $\begin{array}{l}-0.428^{*} \\
(0.237)\end{array}$ & & $\begin{array}{c}0.075 \\
(0.258)\end{array}$ & & $\begin{array}{l}-0.005 \\
(0.145)\end{array}$ & \\
\hline$D E B T \_E X T \_D U R$ & & $\begin{array}{l}0.112 * \\
(0.057)\end{array}$ & & $\begin{array}{l}-0.010 \\
(0.018)\end{array}$ & & $\begin{array}{c}0.004 \\
(0.024)\end{array}$ & & $\begin{array}{c}0.012 \\
(0.015)\end{array}$ \\
\hline Government(-1) & $\begin{array}{c}-0.996^{* * *} \\
(0.129)\end{array}$ & $\begin{array}{c}-0.988^{* * *} \\
(0.135)\end{array}$ & $\begin{array}{c}-0.983 * * * \\
(0.119)\end{array}$ & $\begin{array}{c}-0.965 * * * \\
(0.118)\end{array}$ & $\begin{array}{c}-0.824 * * * \\
(0.125)\end{array}$ & $\begin{array}{c}-0.828 * * * \\
(0.123)\end{array}$ & $\begin{array}{c}-0.935 * * * \\
(0.115)\end{array}$ & $\begin{array}{c}-0.928 * * * \\
(0.112)\end{array}$ \\
\hline POS_SHOCKS & $\begin{array}{l}-7.835 \\
(5.246)\end{array}$ & $\begin{array}{l}-8.810 * \\
(4.774)\end{array}$ & $\begin{array}{l}-1.081 \\
(1.612)\end{array}$ & $\begin{array}{l}-1.467 \\
(1.703)\end{array}$ & $\begin{array}{c}0.120 \\
(1.702)\end{array}$ & $\begin{array}{c}0.133 \\
(1.716)\end{array}$ & $\begin{array}{c}0.075 \\
(0.963)\end{array}$ & $\begin{array}{l}-0.122 \\
(0.944)\end{array}$ \\
\hline NEG_SHOCKS & $\begin{array}{l}12.131 \\
(8.542)\end{array}$ & $\begin{array}{l}11.199 \\
(7.899)\end{array}$ & $\begin{array}{c}1.245 \\
(2.886)\end{array}$ & $\begin{array}{c}1.701 \\
(2.955)\end{array}$ & $\begin{array}{l}-2.686 \\
(4.689)\end{array}$ & $\begin{array}{l}-2.792 \\
(4.805)\end{array}$ & $\begin{array}{c}-3.472 * * \\
(1.734)\end{array}$ & $\begin{array}{c}-3.408 * * \\
(1.702)\end{array}$ \\
\hline$O D A$ & $\begin{array}{c}-156.413^{* *} \\
(59.501)\end{array}$ & $\begin{array}{c}-146.680 * * * \\
(50.692)\end{array}$ & $\begin{array}{c}-6.704 \\
(14.775)\end{array}$ & $\begin{array}{c}-5.500 \\
(15.253)\end{array}$ & $\begin{array}{c}7.553 \\
(18.749)\end{array}$ & $\begin{array}{c}7.603 \\
(20.393)\end{array}$ & $\begin{array}{c}14.042 * \\
(7.718)\end{array}$ & $\begin{array}{l}11.889 \\
(7.612)\end{array}$ \\
\hline$O I L$ & $\begin{array}{c}-39.931 * * * \\
(11.374)\end{array}$ & $\begin{array}{c}-38.285 * * * \\
(12.263)\end{array}$ & $\begin{array}{l}-9.808 \\
(9.261)\end{array}$ & $\begin{array}{l}-12.809 \\
(9.385)\end{array}$ & $\begin{array}{l}-15.760 \\
(11.546)\end{array}$ & $\begin{array}{l}-15.234 \\
(11.431)\end{array}$ & $\begin{array}{c}1.798 \\
(6.783)\end{array}$ & $\begin{array}{c}1.375 \\
(6.691)\end{array}$ \\
\hline$G A P$ & $\begin{array}{l}0.832 * \\
(0.488)\end{array}$ & $\begin{array}{c}0.576 \\
(0.453)\end{array}$ & $\begin{array}{l}-0.405 * \\
(0.211)\end{array}$ & $\begin{array}{c}-0.359 * \\
(0.213)\end{array}$ & $\begin{array}{l}-0.448 \\
(0.338)\end{array}$ & $\begin{array}{l}-0.459 \\
(0.335)\end{array}$ & $\begin{array}{l}-0.056 \\
(0.169)\end{array}$ & $\begin{array}{l}-0.058 \\
(0.160)\end{array}$ \\
\hline CONFLICT & $\begin{array}{l}1.418^{*} \\
(0.722) \\
\end{array}$ & $\begin{array}{l}1.344^{*} \\
(0.718) \\
\end{array}$ & $\begin{array}{l}-0.305 \\
(0.404) \\
\end{array}$ & $\begin{array}{l}-0.235 \\
(0.451) \\
\end{array}$ & $\begin{array}{c}0.335 \\
(0.301) \\
\end{array}$ & $\begin{array}{c}0.325 \\
(0.285) \\
\end{array}$ & $\begin{array}{c}0.126 \\
(0.116) \\
\end{array}$ & $\begin{array}{c}0.155 \\
(0.113) \\
\end{array}$ \\
\hline Observations & 151 & 151 & 143 & 143 & 146 & 146 & 142 & 142 \\
\hline $\mathrm{R}^{2}$ & 0.724 & 0.729 & 0.535 & 0.518 & 0.654 & 0.653 & 0.599 & 0.602 \\
\hline
\end{tabular}

Notes: $* * *$, and *** denote statistical significance at the 10,5 , and $1 \%$ levels, respectively. Clustered standard errors are in the parentheses. Period and countrylevel fixed effects and a constant are included in all regressions though not reported. 
Table A8: Effects of internal debt crises and their durations on 10-year changes in government size/scope, 1961-2010: full set of controls included.

\begin{tabular}{|c|c|c|c|c|c|c|c|c|}
\hline & \multicolumn{2}{|c|}{$G / G D P$} & $P R C$ & $R T Y$ & & & \multicolumn{2}{|c|}{ REGULATION } \\
\hline$D E B T \_I N T$ & $\begin{array}{c}1.049 \\
(0.754)\end{array}$ & & $\begin{array}{l}-0.171 \\
(0.264)\end{array}$ & & $\begin{array}{l}-0.252 \\
(0.410)\end{array}$ & & $\begin{array}{c}0.211 \\
(0.230)\end{array}$ & \\
\hline DEBT_INT_DUR & & $\begin{array}{l}-0.037 \\
(0.037)\end{array}$ & & $\begin{array}{c}0.014 \\
(0.022)\end{array}$ & & $\begin{array}{l}-0.058 \\
(0.063)\end{array}$ & & $\begin{array}{c}0.007 \\
(0.015)\end{array}$ \\
\hline Government(-1) & $\begin{array}{c}-1.026^{* * *} \\
(0.120)\end{array}$ & $\begin{array}{c}-1.018^{* * *} \\
(0.125)\end{array}$ & $\begin{array}{c}-0.964 * * * \\
(0.117)\end{array}$ & $\begin{array}{c}-0.961 * * * \\
(0.116)\end{array}$ & $\begin{array}{c}-0.835^{* * *} \\
(0.112)\end{array}$ & $\begin{array}{c}-0.841^{* * *} \\
(0.112)\end{array}$ & $\begin{array}{c}-0.908^{* * *} \\
(0.124)\end{array}$ & $\begin{array}{c}-0.929 * * * \\
(0.122)\end{array}$ \\
\hline POS_SHOCKS & $\begin{array}{l}-6.651 \\
(5.292)\end{array}$ & $\begin{array}{l}-6.547 \\
(5.423)\end{array}$ & $\begin{array}{l}-1.609 \\
(1.680)\end{array}$ & $\begin{array}{l}-1.656 \\
(1.695)\end{array}$ & $\begin{array}{c}0.302 \\
(1.783)\end{array}$ & $\begin{array}{c}0.101 \\
(1.785)\end{array}$ & $\begin{array}{l}-0.094 \\
(0.894)\end{array}$ & $\begin{array}{c}0.042 \\
(0.910)\end{array}$ \\
\hline$N E G \_S H O C K S$ & $\begin{array}{l}12.687 \\
(8.303)\end{array}$ & $\begin{array}{l}12.195 \\
(8.725)\end{array}$ & $\begin{array}{c}1.748 \\
(2.991)\end{array}$ & $\begin{array}{c}1.748 \\
(3.064)\end{array}$ & $\begin{array}{l}-3.009 \\
(4.771)\end{array}$ & $\begin{array}{l}-2.620 \\
(4.759)\end{array}$ & $\begin{array}{l}-3.414 * \\
(1.774)\end{array}$ & $\begin{array}{c}-3.528^{* *} \\
(1.707)\end{array}$ \\
\hline$O D A$ & $\begin{array}{c}-155.055^{* *} \\
(65.201)\end{array}$ & $\begin{array}{c}-155.664 * * \\
(64.846)\end{array}$ & $\begin{array}{c}-3.351 \\
(12.257)\end{array}$ & $\begin{array}{c}-3.713 \\
(12.605)\end{array}$ & $\begin{array}{c}6.841 \\
(18.306)\end{array}$ & $\begin{array}{c}8.159 \\
(18.367)\end{array}$ & $\begin{array}{l}14.945^{*} \\
(7.576)\end{array}$ & $\begin{array}{l}13.792 * \\
(7.727)\end{array}$ \\
\hline OIL & $\begin{array}{c}-41.295 * * * \\
(13.757)\end{array}$ & $\begin{array}{c}-38.108^{* * *} \\
(13.750)\end{array}$ & $\begin{array}{l}-12.391 \\
(9.337)\end{array}$ & $\begin{array}{l}-13.597 \\
(9.574)\end{array}$ & $\begin{array}{l}-13.332 \\
(11.359)\end{array}$ & $\begin{array}{l}-13.929 \\
(10.746)\end{array}$ & $\begin{array}{c}0.434 \\
(6.502)\end{array}$ & $\begin{array}{c}1.663 \\
(6.643)\end{array}$ \\
\hline$G A P$ & $\begin{array}{c}0.949 * \\
(0.551)\end{array}$ & $\begin{array}{c}0.696 \\
(0.537)\end{array}$ & $\begin{array}{l}-0.406^{*} \\
(0.215)\end{array}$ & $\begin{array}{l}-0.348 \\
(0.220)\end{array}$ & $\begin{array}{l}-0.498 \\
(0.319)\end{array}$ & $\begin{array}{l}-0.584 * \\
(0.295)\end{array}$ & $\begin{array}{l}-0.028 \\
(0.166)\end{array}$ & $\begin{array}{l}-0.042 \\
(0.179)\end{array}$ \\
\hline CONFLICT & $\begin{array}{c}1.345 \\
(0.873) \\
\end{array}$ & $\begin{array}{c}1.255 \\
(0.828) \\
\end{array}$ & $\begin{array}{l}-0.243 \\
(0.465) \\
\end{array}$ & $\begin{array}{l}-0.220 \\
(0.460) \\
\end{array}$ & $\begin{array}{c}0.299 \\
(0.271) \\
\end{array}$ & $\begin{array}{c}0.282 \\
(0.272) \\
\end{array}$ & $\begin{array}{c}0.134 \\
(0.105) \\
\end{array}$ & $\begin{array}{c}0.128 \\
(0.103) \\
\end{array}$ \\
\hline Observations & 151 & 151 & 143 & 143 & 146 & 146 & 142 & 142 \\
\hline $\mathrm{R}^{2}$ & 0.715 & 0.710 & 0.518 & 0.517 & 0.655 & 0.661 & 0.604 & 0.599 \\
\hline
\end{tabular}

Notes: ${ }^{* * *}$, and $* * *$ denote statistical significance at the 10,5 , and $1 \%$ levels, respectively. Clustered standard errors are in the parentheses. Period and countrylevel fixed effects and a constant are included in all regressions though not reported. 
Table A9: Effects of currency crises and their durations on 10-year changes in government size/scope, 1961-2010: full set of controls included. $\Delta$ Government

\begin{tabular}{|c|c|c|c|c|c|c|c|c|}
\hline & \multicolumn{2}{|c|}{$G / G D P$} & \multicolumn{2}{|c|}{ PROPERTY } & \multicolumn{2}{|c|}{ TRADE } & \multicolumn{2}{|c|}{ REGULATION } \\
\hline \multirow[t]{2}{*}{ CURRENCY } & 0.637 & & 0.079 & & $0.466^{*}$ & & $0.369 *$ & \\
\hline & $(0.466)$ & & $(0.248)$ & & $(0.267)$ & & $(0.196)$ & \\
\hline \multirow[t]{2}{*}{ CURRENCY_DUR } & & $-0.058 * *$ & & 0.009 & & 0.024 & & 0.004 \\
\hline & & $(0.027)$ & & $(0.023)$ & & $(0.023)$ & & $(0.020)$ \\
\hline \multirow[t]{2}{*}{ Government(-1) } & $-1.013 * * *$ & $-1.026^{* * *}$ & $-0.955 * * *$ & $-0.961 * * *$ & $-0.788 * * *$ & $-0.820 * * *$ & $-0.919 * * *$ & $-0.934 * * *$ \\
\hline & $(0.121)$ & $(0.126)$ & $(0.127)$ & $(0.117)$ & $(0.122)$ & $(0.122)$ & $(0.106)$ & $(0.116)$ \\
\hline \multirow[t]{2}{*}{ POS_SHOCKS } & -5.940 & -6.106 & -1.617 & -1.721 & 0.662 & 0.136 & 0.467 & 0.041 \\
\hline & $(5.422)$ & $(5.386)$ & $(1.739)$ & $(1.678)$ & $(1.799)$ & $(1.781)$ & $(0.786)$ & $(0.966)$ \\
\hline \multirow[t]{2}{*}{$N E G \_S H O C K S$} & 12.792 & 11.371 & 1.890 & 1.889 & -2.075 & -2.586 & $-3.249 * *$ & $-3.450 * *$ \\
\hline & $(8.941)$ & $(8.446)$ & $(3.107)$ & $(3.047)$ & $(4.536)$ & $(4.689)$ & $(1.535)$ & $(1.678)$ \\
\hline \multirow[t]{2}{*}{$O D A$} & $-155.659 * *$ & $-151.032 * *$ & -3.439 & -4.422 & 7.358 & 4.643 & $14.122 * *$ & 13.364 \\
\hline & $(65.701)$ & $(64.981)$ & $(12.686)$ & $(12.864)$ & (19.372) & $(17.750)$ & $(7.018)$ & $(8.044)$ \\
\hline \multirow[t]{2}{*}{ OIL } & $-40.082 * * *$ & $-37.444 * * *$ & -13.333 & -13.043 & -15.770 & -14.145 & 1.831 & 1.972 \\
\hline & $(13.527)$ & $(12.707)$ & $(9.391)$ & $(9.685)$ & $(10.427)$ & (11.309) & $(5.979)$ & $(6.453)$ \\
\hline \multirow[t]{2}{*}{$G A P$} & 0.769 & 0.762 & $-0.375^{*}$ & $-0.374 *$ & -0.438 & -0.446 & -0.061 & -0.054 \\
\hline & $(0.508)$ & $(0.502)$ & $(0.206)$ & $(0.203)$ & $(0.335)$ & $(0.335)$ & $(0.168)$ & $(0.169)$ \\
\hline \multirow[t]{2}{*}{ CONFLICT } & 1.084 & 1.280 & -0.248 & -0.231 & 0.200 & 0.319 & 0.043 & 0.127 \\
\hline & $(0.828)$ & $(0.811)$ & $(0.470)$ & $(0.459)$ & $(0.297)$ & $(0.286)$ & $(0.105)$ & $(0.102)$ \\
\hline Observations & 151 & 151 & 143 & 143 & 146 & 146 & 142 & 142 \\
\hline $\mathrm{R}^{2}$ & 0.713 & 0.713 & 0.517 & 0.517 & 0.665 & 0.657 & 0.629 & 0.599 \\
\hline
\end{tabular}

Notes: $*, * *$, and *** denote statistical significance at the 10,5 , and $1 \%$ levels, respectively. Clustered standard errors are in the parentheses. Period and countrylevel fixed effects and a constant are included in all regressions though not reported. 
Table A10: Effects of inflation crises and their durations on 10-year changes in government size/scope, 1961-2010: full set of controls included.

$$
\Delta \text { Government }
$$

\begin{tabular}{|c|c|c|c|c|c|c|c|c|}
\hline & \multicolumn{2}{|c|}{$G / G D P$} & \multicolumn{2}{|c|}{ PROPERTY } & \multicolumn{2}{|c|}{ TRADE } & \multicolumn{2}{|c|}{ REGULATION } \\
\hline \multirow[t]{2}{*}{ INFLATION } & 0.092 & & 0.271 & & 0.453 & & 0.172 & \\
\hline & $(0.560)$ & & $(0.200)$ & & $(0.293)$ & & $(0.182)$ & \\
\hline \multirow{2}{*}{ INFLATION_DUR } & & 0.005 & & 0.023 & & 0.037 & & -0.027 \\
\hline & & $(0.042)$ & & $(0.021)$ & & $(0.025)$ & & $(0.016)$ \\
\hline \multirow[t]{2}{*}{ Government(-1) } & $-1.018 * * *$ & $-1.018 * * *$ & $-0.952 * * *$ & $-0.958 * * *$ & $-0.793 * * *$ & $-0.763 * * *$ & $-0.948 * * *$ & $-0.926 * * *$ \\
\hline & $(0.125)$ & $(0.125)$ & $(0.117)$ & $(0.114)$ & $(0.115)$ & $(0.118)$ & $(0.105)$ & $(0.113)$ \\
\hline \multirow[t]{2}{*}{ POS_SHOCKS } & -6.428 & -6.548 & -1.505 & -1.879 & 0.612 & 0.109 & 0.211 & 0.299 \\
\hline & $(5.527)$ & $(5.504)$ & $(1.651)$ & $(1.640)$ & $(1.585)$ & $(1.701)$ & $(0.762)$ & $(0.942)$ \\
\hline \multirow[t]{2}{*}{ NEG_SHOCKS } & 12.137 & 12.100 & 1.823 & 1.792 & -2.456 & -2.325 & $-3.455 * *$ & $-3.397^{*}$ \\
\hline & $(8.764)$ & $(8.679)$ & $(2.951)$ & $(2.955)$ & (4.319) & $(4.525)$ & $(1.567)$ & $(1.743)$ \\
\hline \multirow[t]{2}{*}{$O D A$} & $-155.740 * *$ & $-156.184 * *$ & -2.903 & -4.505 & 8.830 & 6.333 & 12.052 & $20.824 * * *$ \\
\hline & (64.176) & $(65.521)$ & $(11.328)$ & $(10.526)$ & $(16.496)$ & $(15.926)$ & $(8.473)$ & $(7.727)$ \\
\hline \multirow[t]{2}{*}{ OIL } & $-39.226 * * *$ & $-39.251 * * *$ & -12.749 & -12.469 & -14.468 & -14.235 & 2.381 & 0.168 \\
\hline & $(13.274)$ & $(13.274)$ & $(8.486)$ & $(8.945)$ & $(9.764)$ & $(10.101)$ & $(6.204)$ & $(6.658)$ \\
\hline \multirow[t]{2}{*}{$G A P$} & 0.791 & 0.772 & -0.329 & $-0.391 *$ & -0.355 & -0.459 & -0.027 & -0.046 \\
\hline & $(0.513)$ & $(0.499)$ & $(0.208)$ & $(0.199)$ & $(0.350)$ & $(0.330)$ & $(0.178)$ & $(0.162)$ \\
\hline \multirow[t]{2}{*}{ CONFLICT } & 1.283 & 1.277 & -0.202 & -0.229 & 0.366 & 0.354 & 0.143 & 0.116 \\
\hline & $(0.851)$ & $(0.842)$ & $(0.482)$ & $(0.462)$ & $(0.266)$ & $(0.274)$ & $(0.115)$ & $(0.111)$ \\
\hline Observations & 151 & 151 & 143 & 143 & 146 & 146 & 142 & 142 \\
\hline $\mathrm{R}^{2}$ & 0.709 & 0.709 & 0.525 & 0.527 & 0.665 & 0.665 & 0.606 & 0.624 \\
\hline
\end{tabular}

Notes: * **, and *** denote statistical significance at the 10,5 , and $1 \%$ levels, respectively. Clustered standard errors are in the parentheses. Period and countrylevel fixed effects and a constant are included in all regressions though not reported. 
Table A11. Effects of banking crises on 5-year changes in government size/scope, 1966-2010: full set of controls and interaction term included.

\begin{tabular}{lcccc}
\hline \hline & $\Delta$ Government & & & \\
& G/GDP & PROPERTY & TRADE & REGULATION \\
\hline \hline BANK & $-10.590^{* * *}$ & -0.655 & -2.188 & 0.682 \\
GDP & $(3.945)$ & $(1.400)$ & $(1.912)$ & $(0.817)$ \\
& 0.300 & 0.574 & $-1.068^{* *}$ & -0.352 \\
GDP*BANK & $(1.316)$ & $(0.424)$ & $(0.464)$ & $(0.412)$ \\
& $1.226^{* *}$ & 0.124 & 0.268 & -0.060 \\
Government(-1) & $(0.466)$ & $(0.164)$ & $(0.224)$ & $(0.101)$ \\
& $-0.616^{* * *}$ & $-0.552^{* * *}$ & $-0.512^{* * *}$ & $-0.589^{* * *}$ \\
POS_SHOCKS & $(0.112)$ & $(0.071)$ & $(0.060)$ & $(0.088)$ \\
& -1.330 & 0.246 & $2.612^{* *}$ & 0.361 \\
NEG_SHOCKS & $(2.693)$ & $(0.884)$ & $(1.249)$ & $(0.543)$ \\
ODA & $4.431^{*}$ & 0.374 & 0.088 & $-1.554^{* * *}$ \\
& $(2.601)$ & $(1.608)$ & $(1.828)$ & $(0.563)$ \\
OIL & -33.271 & 6.787 & 8.274 & 5.363 \\
& $(45.617)$ & $(4.622)$ & $(7.251)$ & $(5.785)$ \\
GAP & $-19.847^{* *}$ & 1.980 & $-10.357^{*}$ & -0.238 \\
& $(8.851)$ & $(3.917)$ & $(5.844)$ & $(2.159)$ \\
CONFLICT & 0.382 & -0.113 & -0.225 & -0.152 \\
& $(0.292)$ & $(0.149)$ & $(0.158)$ & $(0.105)$ \\
\hline \hline Observations & $1.211^{*}$ & -0.158 & 0.203 & -0.092 \\
$\mathrm{R}^{2}$ & $(0.707)$ & $(0.266)$ & $(0.173)$ & $(0.117)$ \\
\hline \hline
\end{tabular}

Notes: ${ }^{*}, * *$, and $* * *$ denote statistical significance at the 10,5 , and $1 \%$ levels, respectively. Clustered standard errors are in the parentheses. Period and country-level fixed effects and a constant are included in all regressions though not reported. 
Table A12: Effects of external sovereign debt crises on 5-year changes in government size/scope, 1966-2010: full set of controls and interaction term included.

\begin{tabular}{|c|c|c|c|c|}
\hline & $\Delta$ Governmer & & & \\
\hline & $G / G D P$ & PROPERTY & TRADE & REGULATION \\
\hline DEBT_EXT & 7.356 & $-3.648 * *$ & $-5.713 * * *$ & -0.020 \\
\hline & $(5.453)$ & $(1.596)$ & $(1.543)$ & (1.404) \\
\hline$G D P$ & -0.778 & $0.414^{* *}$ & $0.684 * * *$ & 0.011 \\
\hline & $(0.651)$ & $(0.197)$ & $(0.196)$ & $(0.172)$ \\
\hline$G D P^{*} D E B T \_E X T$ & 0.633 & 0.362 & $-1.063 * *$ & -0.398 \\
\hline & $(1.355)$ & $(0.387)$ & $(0.414)$ & $(0.420)$ \\
\hline Government(-1) & $-0.611 * * *$ & $-0.594 * * *$ & $-0.495 * * *$ & $-0.596^{* * *}$ \\
\hline & $(0.118)$ & $(0.077)$ & $(0.058)$ & $(0.089)$ \\
\hline POS_SHOCKS & -0.480 & -0.348 & 1.960 & 0.391 \\
\hline & $(2.740)$ & $(0.911)$ & $(1.257)$ & $(0.589)$ \\
\hline$N E G \_S H O C K S$ & 2.092 & 0.832 & 0.796 & $-1.692 * * *$ \\
\hline & $(2.711)$ & (1.417) & (1.563) & $(0.626)$ \\
\hline$O D A$ & -29.540 & 3.520 & 6.001 & 5.869 \\
\hline & $(46.035)$ & (5.098) & (6.099) & $(6.180)$ \\
\hline OIL & $-18.646^{* *}$ & 0.872 & $-10.003^{*}$ & -0.428 \\
\hline & $(8.344)$ & $(3.577)$ & $(5.809)$ & $(2.176)$ \\
\hline$G A P$ & $0.481 *$ & -0.093 & -0.143 & -0.162 \\
\hline & $(0.253)$ & $(0.149)$ & $(0.163)$ & $(0.105)$ \\
\hline CONFLICT & 1.084 & -0.143 & 0.182 & -0.067 \\
\hline & $(0.733)$ & $(0.274)$ & $(0.163)$ & $(0.119)$ \\
\hline Observations & 274 & 264 & 267 & 262 \\
\hline $\mathrm{R}^{2}$ & 0.396 & 0.472 & 0.555 & 0.436 \\
\hline
\end{tabular}

Notes: ${ }^{*}, * *$, and $* * *$ denote statistical significance at the 10,5 , and $1 \%$ levels, respectively. Clustered standard errors are in the parentheses. Period and country-level fixed effects and a constant are included in all regressions though not reported. 
Table A13: Effects of internal sovereign debt crises on 5-year changes in government size/scope, 1966-2010: full set of controls and interaction term included.

\begin{tabular}{lcccc}
\hline \hline \multicolumn{1}{c}{$\Delta$ Government } & & & \\
& G/GDP & PROPERTY & TRADE & REGULATION \\
\hline \hline DEBT_INT & -6.380 & 2.162 & -1.946 & -2.778 \\
GDP & $(5.358)$ & $(3.103)$ & $(3.119)$ & $(2.301)$ \\
& 0.725 & -0.236 & 0.291 & 0.321 \\
GDP*DEBT_INT & $(0.608)$ & $(0.372)$ & $(0.381)$ & $(0.262)$ \\
& 0.541 & 0.473 & $-1.033^{* *}$ & -0.380 \\
Government(-1) & $(1.327)$ & $(0.417)$ & $(0.471)$ & $(0.413)$ \\
& $-0.631^{* * *}$ & $-0.570^{* * *}$ & $-0.492^{* * *}$ & $-0.599^{* * *}$ \\
POS_SHOCKS & $(0.126)$ & $(0.074)$ & $(0.058)$ & $(0.092)$ \\
& -1.354 & 0.023 & $2.310^{*}$ & 0.444 \\
NEG_SHOCKS & $(2.650)$ & $(0.954)$ & $(1.314)$ & $(0.506)$ \\
& 4.056 & 0.185 & 0.022 & $-1.680^{* * *}$ \\
ODA & $(2.792)$ & $(1.543)$ & $(1.744)$ & $(0.598)$ \\
& -34.900 & $7.720^{*}$ & 8.538 & 5.462 \\
OIL & $(47.650)$ & $(4.606)$ & $(7.666)$ & $(5.951)$ \\
& $-20.572^{* *}$ & 0.925 & $-10.524^{*}$ & -0.359 \\
GAP & $(9.288)$ & $(3.640)$ & $(5.716)$ & $(2.064)$ \\
& $0.524 * *$ & -0.126 & -0.165 & -0.153 \\
CONFLICT & $(0.257)$ & $(0.149)$ & $(0.159)$ & $(0.107)$ \\
& 1.134 & -0.153 & 0.175 & -0.053 \\
\hline \hline Observations & $(0.749)$ & $(0.276)$ & $(0.164)$ & $(0.115)$ \\
$\mathrm{R}^{2}$ & 274 & 264 & 267 & 262 \\
\hline Notes:***an & 0.374 & 0.452 & 0.440 \\
\hline
\end{tabular}

Notes: ${ }^{*}, * *$, and $* * *$ denote statistical significance at the 10,5 , and $1 \%$ levels, respectively. Clustered standard errors are in the parentheses. Period and country-level fixed effects and a constant are included in all regressions though not reported. 
Table A14: Effects of currency crises on 5-year changes in government size/scope, 1966-2010: full set of controls and interaction term included.

\begin{tabular}{lcccc}
\hline \hline \multicolumn{1}{c}{$\Delta$ Government } & & & \\
& G/GDP & PROPERTY & TRADE & REGULATION \\
\hline \hline CURRENCY & 1.280 & -0.363 & -0.461 & 0.568 \\
GDP & $(3.694)$ & $(1.095)$ & $(1.155)$ & $(0.591)$ \\
& -0.146 & 0.043 & 0.040 & -0.077 \\
GDP*CURRENCY & $(0.405)$ & $(0.122)$ & $(0.131)$ & $(0.066)$ \\
& 0.606 & 0.465 & $-1.112^{* *}$ & -0.418 \\
Government(-1) & $(1.501)$ & $(0.403)$ & $(0.492)$ & $(0.458)$ \\
& $-0.636^{* * *}$ & $-0.582^{* * *}$ & $-0.516^{* * *}$ & $-0.606^{* * *}$ \\
POS_SHOCKS & $(0.128)$ & $(0.073)$ & $(0.060)$ & $(0.095)$ \\
NEG_SHOCKS & -1.657 & 0.125 & $2.486^{*}$ & 0.322 \\
& $(2.942)$ & $(0.835)$ & $(1.247)$ & $(0.538)$ \\
ODA & 4.102 & 0.106 & -0.045 & $-1.562^{* *}$ \\
& $(2.733)$ & $(1.528)$ & $(1.772)$ & $(0.601)$ \\
OIL & -34.968 & 7.495 & 8.390 & 5.575 \\
& $(47.782)$ & $(4.661)$ & $(7.577)$ & $(6.022)$ \\
GAP & $-20.493^{* *}$ & 0.920 & $-10.791^{*}$ & -0.886 \\
& $(9.078)$ & $(3.666)$ & $(5.781)$ & $(2.119)$ \\
CONFLICT & $0.502^{*}$ & -0.117 & -0.204 & -0.172 \\
& $(0.259)$ & $(0.151)$ & $(0.166)$ & $(0.107)$ \\
\hline \hline Observations & 1.076 & -0.139 & 0.211 & -0.061 \\
$\mathrm{R}^{2}$ & $(0.722)$ & $(0.279)$ & $(0.173)$ & $(0.120)$ \\
\hline \hline Notes: & 274 & 264 & 267 & 262 \\
& 0.373 & 0.450 & 0.533 & 0.440 \\
\hline
\end{tabular}

Notes: ${ }^{*}, * *$, and ${ }^{* * *}$ denote statistical significance at the 10,5 , and $1 \%$ levels, respectively. Clustered standard errors are in the parentheses. Period and country-level fixed effects and a constant are included in all regressions though not reported. 
Table A15: Effects of inflation crises on 5-year changes in government size/scope, 1966-2010: full set of controls and interaction term included.

\begin{tabular}{lcccc}
\hline & $\Delta$ Government & & & \\
& G/GDP & PROPERTY & TRADE & REGULATION \\
\hline \hline INFLATION & -9.302 & -1.290 & $-3.406^{*}$ & 0.690 \\
GDP & $(7.237)$ & $(1.477)$ & $(1.761)$ & $(1.251)$ \\
& 1.106 & 0.156 & $0.393^{*}$ & -0.086 \\
GDP*INFLATION & $(0.864)$ & $(0.174)$ & $(0.222)$ & $(0.153)$ \\
& 0.312 & 0.455 & $-1.104^{* *}$ & -0.395 \\
Government(-1) & $(1.297)$ & $(0.405)$ & $(0.466)$ & $(0.436)$ \\
& $-0.622^{* * *}$ & $-0.583^{* * *}$ & $-0.521^{* * *}$ & $-0.600^{* * *}$ \\
POS_SHOCKS & $(0.125)$ & $(0.072)$ & $(0.056)$ & $(0.090)$ \\
NEG_SHOCKS & -1.806 & 0.091 & $2.554^{* *}$ & 0.385 \\
& $(2.663)$ & $(0.905)$ & $(1.236)$ & $(0.564)$ \\
ODA & 4.888 & 0.239 & 0.092 & $-1.686 * *$ \\
& $(3.037)$ & $(1.553)$ & $(1.680)$ & $(0.657)$ \\
OIL & -45.025 & 5.856 & 3.674 & 6.509 \\
& $(43.589)$ & $(4.489)$ & $(5.706)$ & $(6.920)$ \\
GAP & $-20.023^{* *}$ & 0.999 & $-9.930^{*}$ & -0.594 \\
& $(9.177)$ & $(3.814)$ & $(5.842)$ & $(2.077)$ \\
CONFLICT & $0.488^{*}$ & -0.120 & -0.227 & -0.168 \\
& $(0.260)$ & $(0.147)$ & $(0.160)$ & $(0.110)$ \\
\hline \hline Observations & 1.077 & -0.147 & 0.179 & -0.065 \\
$\mathrm{R}^{2}$ & $(0.708)$ & $(0.276)$ & $(0.173)$ & $(0.123)$ \\
\hline \hline
\end{tabular}

Notes: ${ }^{*}, * *$, and $* * *$ denote statistical significance at the 10,5 , and $1 \%$ levels, respectively. Clustered standard errors are in the parentheses. Period and country-level fixed effects and a constant are included in all regressions though not reported. 
Table A16: Effects of banking crises on 10-year changes in government size/scope, 1961-2010: full set of controls and interaction term included.

\begin{tabular}{lcccc}
\hline \hline & $\Delta$ Government & & & \\
& G/GDP & PROPERTY & TRADE & REGULATION \\
\hline \hline BANK & 5.651 & 0.097 & $4.267^{*}$ & 0.674 \\
GDP & $(5.426)$ & $(2.368)$ & $(2.390)$ & $(1.197)$ \\
& -2.438 & 0.709 & -0.280 & -0.309 \\
GDP*BANK & $(1.636)$ & $(0.765)$ & $(0.948)$ & $(0.678)$ \\
& -0.615 & 0.004 & $-0.519 *$ & -0.079 \\
Government(-1) & $(0.647)$ & $(0.285)$ & $(0.284)$ & $(0.143)$ \\
& $-0.972^{* * *}$ & $-0.937^{* * *}$ & $-0.812 * * *$ & $-0.951^{* * *}$ \\
POS_SHOCKS & $(0.135)$ & $(0.130)$ & $(0.107)$ & $(0.120)$ \\
NEG_SHOCKS & -5.463 & -1.307 & 0.082 & 0.023 \\
ODA & $(5.492)$ & $(1.563)$ & $(1.771)$ & $(0.936)$ \\
& 12.816 & 0.673 & -2.981 & $-3.138^{*}$ \\
OIL & $(9.982)$ & $(3.510)$ & $(4.269)$ & $(1.688)$ \\
& $-188.978^{* * *}$ & 0.235 & -2.265 & 10.747 \\
GAP & $(60.138)$ & $(12.182)$ & $(24.156)$ & $(7.988)$ \\
& $-41.630^{* * *}$ & -9.363 & -14.878 & 0.487 \\
CONFLICT & $(12.570)$ & $(10.434)$ & $(10.298)$ & $(6.837)$ \\
& $1.133^{*}$ & $-0.446 * *$ & -0.356 & -0.002 \\
\hline \hline Observations & $(0.599)$ & $(0.217)$ & $(0.339)$ & $(0.175)$ \\
$\mathrm{R}^{2}$ & 1.385 & -0.252 & 0.355 & 0.138 \\
\hline \hline
\end{tabular}

Notes: ${ }^{*}, * *$, and $* * *$ denote statistical significance at the 10,5 , and $1 \%$ levels, respectively. Clustered standard errors are in the parentheses. Period and country-level fixed effects and a constant are included in all regressions though not reported. 
Table A17: Effects of external sovereign debt crises on 10-year changes in government size/scope, 1961-2010: full set of controls and interaction term included.

\begin{tabular}{|c|c|c|c|c|}
\hline & $\Delta$ Government & & & \\
\hline & $G / G D P$ & PROPERTY & TRADE & REGULATION \\
\hline DEBT_EXT & 1.183 & 0.875 & 0.526 & $-3.241 * *$ \\
\hline & (6.479) & (3.102) & (3.094) & (1.384) \\
\hline$G D P$ & -2.285 & 0.517 & -0.691 & -0.407 \\
\hline & (1.936) & $(0.690)$ & $(0.861)$ & $(0.642)$ \\
\hline$G D P^{*} D E B T \_E X T$ & -0.024 & -0.161 & -0.061 & $0.404 * *$ \\
\hline & $(0.773)$ & $(0.394)$ & $(0.390)$ & $(0.180)$ \\
\hline Government(-1) & $-1.005 * * *$ & $-0.960 * * *$ & $-0.823 * * *$ & $-0.915 * * *$ \\
\hline & $(0.151)$ & $(0.140)$ & $(0.129)$ & $(0.118)$ \\
\hline POS_SHOCKS & -7.656 & -1.138 & -0.027 & 0.387 \\
\hline & (5.016) & (1.686) & (1.708) & (1.039) \\
\hline$N E G \_S H O C K S$ & 14.570 & 0.262 & -1.799 & -2.010 \\
\hline & (11.106) & $(3.438)$ & $(4.843)$ & (1.579) \\
\hline$O D A$ & $-169.606^{* *}$ & -6.360 & 2.323 & $25.297 * *$ \\
\hline & $(66.891)$ & (13.879) & (18.821) & $(10.676)$ \\
\hline OIL & $-41.897 * * *$ & -5.682 & -18.254 & -3.735 \\
\hline & (11.896) & $(9.587)$ & (11.078) & $(6.702)$ \\
\hline$G A P$ & $1.073^{*}$ & $-0.464^{*}$ & -0.364 & 0.001 \\
\hline & $(0.568)$ & $(0.235)$ & $(0.366)$ & $(0.172)$ \\
\hline CONFLICT & $1.449^{* *}$ & -0.276 & 0.375 & 0.013 \\
\hline & $(0.712)$ & $(0.421)$ & $(0.325)$ & $(0.123)$ \\
\hline Observations & 151 & 143 & 146 & 142 \\
\hline $\mathrm{R}^{2}$ & 0.732 & 0.539 & 0.658 & 0.622 \\
\hline
\end{tabular}

Notes: ${ }^{*}, * *$, and $* * *$ denote statistical significance at the 10,5 , and $1 \%$ levels, respectively. Clustered standard errors are in the parentheses. Period and country-level fixed effects and a constant are included in all regressions though not reported. 
Table A18: Effects of internal sovereign debt crises on 10-year changes in government size/scope, 1961-2010: full set of controls and interaction term included.

\begin{tabular}{|c|c|c|c|c|}
\hline & $\Delta$ Government & & & \\
\hline & $G / G D P$ & PROPERTY & TRADE & REGULATION \\
\hline DEBT_INT & 4.198 & $7.376^{*}$ & 7.766 & -1.751 \\
\hline & $(9.645)$ & $(4.255)$ & $(5.978)$ & (3.279) \\
\hline$G D P$ & -2.901 & 0.531 & -0.825 & -0.368 \\
\hline & $(1.866)$ & $(0.655)$ & $(0.862)$ & $(0.645)$ \\
\hline$G D P^{*} D E B T \_I N T$ & -0.383 & $-0.915^{*}$ & -0.968 & 0.239 \\
\hline & (1.108) & $(0.516)$ & $(0.721)$ & $(0.407)$ \\
\hline Government(-1) & $-1.035 * * *$ & $-0.942 * * *$ & $-0.819 * * *$ & $-0.908 * * *$ \\
\hline & $(0.131)$ & $(0.130)$ & $(0.102)$ & $(0.130)$ \\
\hline POS_SHOCKS & -6.686 & -1.363 & 0.313 & -0.199 \\
\hline & (5.648) & (1.510) & (1.716) & $(0.813)$ \\
\hline$N E G \_S H O C K S$ & 16.020 & 0.991 & -1.638 & -2.853 \\
\hline & (9.998) & (3.172) & $(4.824)$ & (1.773) \\
\hline$O D A$ & $-171.756^{* *}$ & -3.488 & -0.720 & 13.396 \\
\hline & $(64.882)$ & (12.631) & $(21.131)$ & $(8.360)$ \\
\hline OIL & $-44.000 * * *$ & -6.624 & -14.787 & -2.058 \\
\hline & $(12.451)$ & $(9.121)$ & (10.434) & $(6.897)$ \\
\hline$G A P$ & $1.256^{* *}$ & $-0.492 * *$ & -0.418 & 0.032 \\
\hline & $(0.619)$ & $(0.219)$ & $(0.341)$ & $(0.178)$ \\
\hline CONFLICT & $1.418^{*}$ & -0.247 & 0.358 & 0.145 \\
\hline & $(0.844)$ & $(0.446)$ & $(0.259)$ & $(0.111)$ \\
\hline Observations & 151 & 143 & 146 & 142 \\
\hline $\mathrm{R}^{2}$ & 0.729 & 0.539 & 0.668 & 0.611 \\
\hline
\end{tabular}

Notes: ${ }^{*}, * *$, and $* * *$ denote statistical significance at the 10,5 , and $1 \%$ levels, respectively. Clustered standard errors are in the parentheses. Period and country-level fixed effects and a constant are included in all regressions though not reported. 
Table A19: Effects of currency crises on 10-year changes in government size/scope, 1961-2010: full set of controls and interaction term included.

\begin{tabular}{|c|c|c|c|c|}
\hline & $\Delta$ Government & & & \\
\hline & $G / G D P$ & PROPERTY & TRADE & REGULATION \\
\hline CURRENCY & -4.887 & 0.599 & -0.130 & 2.647 \\
\hline & $(9.261)$ & (3.933) & $(4.422)$ & $(2.458)$ \\
\hline$G D P$ & -3.188 & 0.741 & -0.681 & -0.097 \\
\hline & $(2.072)$ & $(0.869)$ & $(0.864)$ & $(0.735)$ \\
\hline$G D P^{*} C U R R E N C Y$ & 0.649 & -0.056 & 0.069 & -0.272 \\
\hline & $(1.068)$ & $(0.450)$ & $(0.514)$ & $(0.285)$ \\
\hline Government(-1) & $-1.024 * * *$ & $-0.937 * * *$ & $-0.791 * * *$ & $-0.911 * * *$ \\
\hline & $(0.133)$ & $(0.132)$ & $(0.125)$ & $(0.116)$ \\
\hline POS_SHOCKS & -6.813 & -1.397 & 0.429 & 0.625 \\
\hline & $(5.837)$ & (1.713) & $(1.866)$ & $(0.795)$ \\
\hline$N E G \_S H O C K S$ & 15.962 & 0.952 & -1.101 & $-2.996^{*}$ \\
\hline & $(10.741)$ & $(3.390)$ & (4.544) & $(1.598)$ \\
\hline$O D A$ & $-172.600^{* * *}$ & 0.400 & 3.766 & 13.540 \\
\hline & $(63.023)$ & (11.969) & $(20.748)$ & $(8.507)$ \\
\hline OIL & $-42.283 * * *$ & -9.707 & $-18.808^{*}$ & 0.449 \\
\hline & $(12.374)$ & $(9.683)$ & (10.187) & $(6.500)$ \\
\hline GAP & $1.140^{*}$ & $-0.452 * *$ & -0.349 & -0.056 \\
\hline & $(0.608)$ & $(0.219)$ & $(0.358)$ & $(0.185)$ \\
\hline CONFLICT & 1.390 & -0.307 & 0.254 & -0.054 \\
\hline & $(0.952)$ & $(0.486)$ & $(0.329)$ & $(0.175)$ \\
\hline Observations & 151 & 143 & 146 & 142 \\
\hline $\mathrm{R}^{2}$ & 0.728 & 0.524 & 0.668 & 0.640 \\
\hline
\end{tabular}

Notes: ${ }^{*}, * *$, and $* * *$ denote statistical significance at the 10,5 , and $1 \%$ levels, respectively. Clustered standard errors are in the parentheses. Period and country-level fixed effects and a constant are included in all regressions though not reported. 
Table A20: Effects of inflation crises on 10-year changes in government size/scope, 1961-2010: full set of controls and interaction term included.

\begin{tabular}{lcccc}
\hline \hline & $\Delta$ Government & & & \\
& G/GDP & PROPERTY & TRADE & REGULATION \\
\hline \hline INFLATION & 6.214 & $-4.536^{* *}$ & -2.255 & 0.552 \\
GDP & $(6.642)$ & $(2.075)$ & $(3.079)$ & $(1.206)$ \\
& -2.499 & 0.514 & -0.766 & -0.293 \\
GDP*INFLATION & $(1.794)$ & $(0.689)$ & $(0.815)$ & $(0.700)$ \\
& -0.771 & $0.596^{* *}$ & 0.333 & -0.049 \\
Government(-1) & $(0.800)$ & $(0.253)$ & $(0.366)$ & $(0.152)$ \\
& $-1.035^{* * *}$ & $-0.966^{* * *}$ & $-0.805^{* * *}$ & $-0.944^{* * *}$ \\
POS_SHOCKS & $(0.137)$ & $(0.125)$ & $(0.112)$ & $(0.111)$ \\
& -6.551 & -1.179 & 0.451 & 0.155 \\
NEG_SHOCKS & $(5.917)$ & $(1.540)$ & $(1.553)$ & $(0.711)$ \\
& 15.002 & 1.331 & -1.444 & $-3.017^{*}$ \\
ODA & $(10.386)$ & $(3.047)$ & $(4.319)$ & $(1.608)$ \\
& $-176.077^{* * *}$ & 6.944 & 6.666 & 10.052 \\
OIL & $(64.695)$ & $(12.860)$ & $(19.420)$ & $(8.589)$ \\
& $-41.992^{* * *}$ & -7.867 & $-16.494^{*}$ & 0.722 \\
GAP & $(11.579)$ & $(7.690)$ & $(8.935)$ & $(6.811)$ \\
& $1.077^{* *}$ & $-0.415^{*}$ & -0.271 & 0.011 \\
CONFLICT & $(0.539)$ & $(0.217)$ & $(0.349)$ & $(0.174)$ \\
& $1.418^{*}$ & -0.340 & 0.348 & 0.161 \\
Observations & $(0.766)$ & $(0.413)$ & $(0.290)$ & $(0.115)$ \\
$\mathrm{R}^{2}$ & 151 & 143 & 146 & 142 \\
\hline \hline
\end{tabular}

Notes: ${ }^{*}, * *$, and $* * *$ denote statistical significance at the 10,5 , and $1 \%$ levels, respectively. Clustered standard errors are in the parentheses. Period and country-level fixed effects and a constant are included in all regressions though not reported. 
Table A21: System GMM effects of banking crises on 5-year changes in government size/scope, 1966-2010: full set of controls and interaction term included.

\begin{tabular}{|c|c|c|c|c|}
\hline & $\Delta$ Governmer & & & \\
\hline & $G / G D P$ & PROPERTY & TRADE & REGULATION \\
\hline$B A N K$ & -0.472 & "0.247* & 0.022 & $\begin{array}{c}0.101 \\
\end{array}$ \\
\hline & $(0.291)$ & $(0.141)$ & $(0.153)$ & $(0.115)$ \\
\hline Government(-1) & $-0.114 * * *$ & $-0.158 * * *$ & $-0.343 * * *$ & $-0.238 * * *$ \\
\hline & $(0.017)$ & $(0.035)$ & $(0.059)$ & $(0.048)$ \\
\hline POS_SHOCKS & 0.258 & -0.089 & -0.228 & -0.113 \\
\hline & $(0.256)$ & $(0.167)$ & $(0.163)$ & $(0.102)$ \\
\hline$N E G \_S H O C K S$ & 4.726 & 1.336 & -1.413 & -1.412 \\
\hline & (13.041) & $(2.031)$ & (3.259) & $(1.735)$ \\
\hline$O D A$ & -3.682 & -0.339 & -2.972 & -0.068 \\
\hline & $(2.848)$ & (1.334) & (2.298) & $(0.745)$ \\
\hline OIL & $-3.718^{*}$ & 0.340 & 2.050 & 0.303 \\
\hline & (1.924) & $(0.687)$ & (1.682) & $(0.548)$ \\
\hline GAP & $5.368^{*}$ & -0.848 & 0.190 & -0.783 \\
\hline & $(2.966)$ & (1.393) & $(2.221)$ & $(0.742)$ \\
\hline CONFLICT & $0.184 * *$ & 0.022 & -0.048 & -0.024 \\
\hline & $(0.081)$ & $(0.070)$ & $(0.075)$ & $(0.029)$ \\
\hline Observations & 248 & 238 & 241 & 238 \\
\hline $\begin{array}{l}\text { Notes: } *, * *, * * * \\
\text { are in parentheses } \\
\text { levels of } G D P, A C \\
\text { instruments. Both } \\
\text { all cases, however } \\
\text { heteroskedasticity }\end{array}$ & $\begin{array}{l}\text { ical significa } \\
\mathrm{d} \text { effects and } \\
E, L I F E_{-} E X \\
\text { and Sargan s } \\
\text { hese statistic } \\
\text { number of in }\end{array}$ & $\begin{array}{l}10,5 \text {, and } 1 \% \\
\text { it are included } \\
C Y \text {, and } I N F A \Lambda \\
\text { iil to reject the } \\
\text { rted as they ha } \\
\text { as in system } C\end{array}$ & $\begin{array}{l}\text { espectively } \\
\text { essions tho } \\
T \text { are includ } \\
\text { thesis that } \\
\text { hown to be }\end{array}$ & $\begin{array}{l}\text { ed standard errors } \\
\text { eported. Lagged } \\
\text { litional exogenous } \\
\text { ments are valid in } \\
\text { e in the presence of }\end{array}$ \\
\hline
\end{tabular}


Table A22: System GMM effects of external debt crises on 5-year changes in government size/scope, 1966-2010: full set of controls and interaction term included.

\begin{tabular}{|c|c|c|c|c|}
\hline \multicolumn{5}{|c|}{$\Delta$ Government } \\
\hline & $G / G D P$ & PROPERTY & TRADE & REGULATION \\
\hline \multirow[t]{2}{*}{$D E B T \_E X T$} & $0.680^{* *}$ & -0.249 & -0.178 & -0.067 \\
\hline & $(0.317)$ & $(0.201)$ & $(0.194)$ & $(0.117)$ \\
\hline \multirow[t]{2}{*}{ Government $(-1)$} & $-0.113 * * *$ & $-0.184 * * *$ & $-0.340 * * *$ & $-0.244 * * *$ \\
\hline & $(0.017)$ & $(0.034)$ & $(0.060)$ & $(0.047)$ \\
\hline \multirow[t]{2}{*}{ POS_SHOCKS } & 0.178 & -0.090 & $-0.251^{*}$ & -0.127 \\
\hline & $(0.255)$ & $(0.173)$ & $(0.142)$ & $(0.097)$ \\
\hline \multirow[t]{2}{*}{ NEG_SHOCKS } & 5.879 & 0.788 & -1.499 & -1.418 \\
\hline & (12.927) & $(2.190)$ & $(3.346)$ & (1.646) \\
\hline \multirow[t]{2}{*}{$O D A$} & -3.411 & -0.394 & -2.957 & -0.067 \\
\hline & $(2.732)$ & $(1.273)$ & $(2.250)$ & $(0.729)$ \\
\hline \multirow[t]{2}{*}{ OIL } & $-4.639 * *$ & 0.578 & 1.972 & 0.370 \\
\hline & $(2.081)$ & $(0.725)$ & $(1.656)$ & $(0.552)$ \\
\hline \multirow[t]{2}{*}{$G A P$} & $5.351^{*}$ & -1.066 & 0.320 & -0.856 \\
\hline & $(2.936)$ & $(1.415)$ & (2.163) & $(0.774)$ \\
\hline \multirow[t]{2}{*}{ CONFLICT } & $0.250 * * *$ & 0.006 & -0.068 & -0.019 \\
\hline & $(0.079)$ & $(0.072)$ & $(0.067)$ & $(0.023)$ \\
\hline Observations & 248 & 238 & 241 & 238 \\
\hline \multicolumn{5}{|c|}{$\begin{array}{l}\text { Notes: } *, * *, * * \text { denote statistical significance at the } 10,5 \text {, and } 1 \% \text { levels, respectively. Clustered standard errors } \\
\text { are in parentheses. Period fixed effects and a constant are included in all regressions though not reported. Lagged } \\
\text { levels of GDP, AGRICULTURE, LIFE_EXPECTANCY, and INFANT_MORT are included as additional exogenous } \\
\text { instruments. Both the Hansen and Sargan statistics fail to reject the null hypothesis that the instruments are valid in } \\
\text { all cases, however, neither of these statistics are reported as they have been shown to be unreliable in the presence of } \\
\text { heteroskedasticity and a large number of instruments as in system GMM. }\end{array}$} \\
\hline
\end{tabular}


Table A23: System GMM effects of internal debt crises on 5-year changes in government size/scope, 1966-2010: full set of controls and interaction term included.

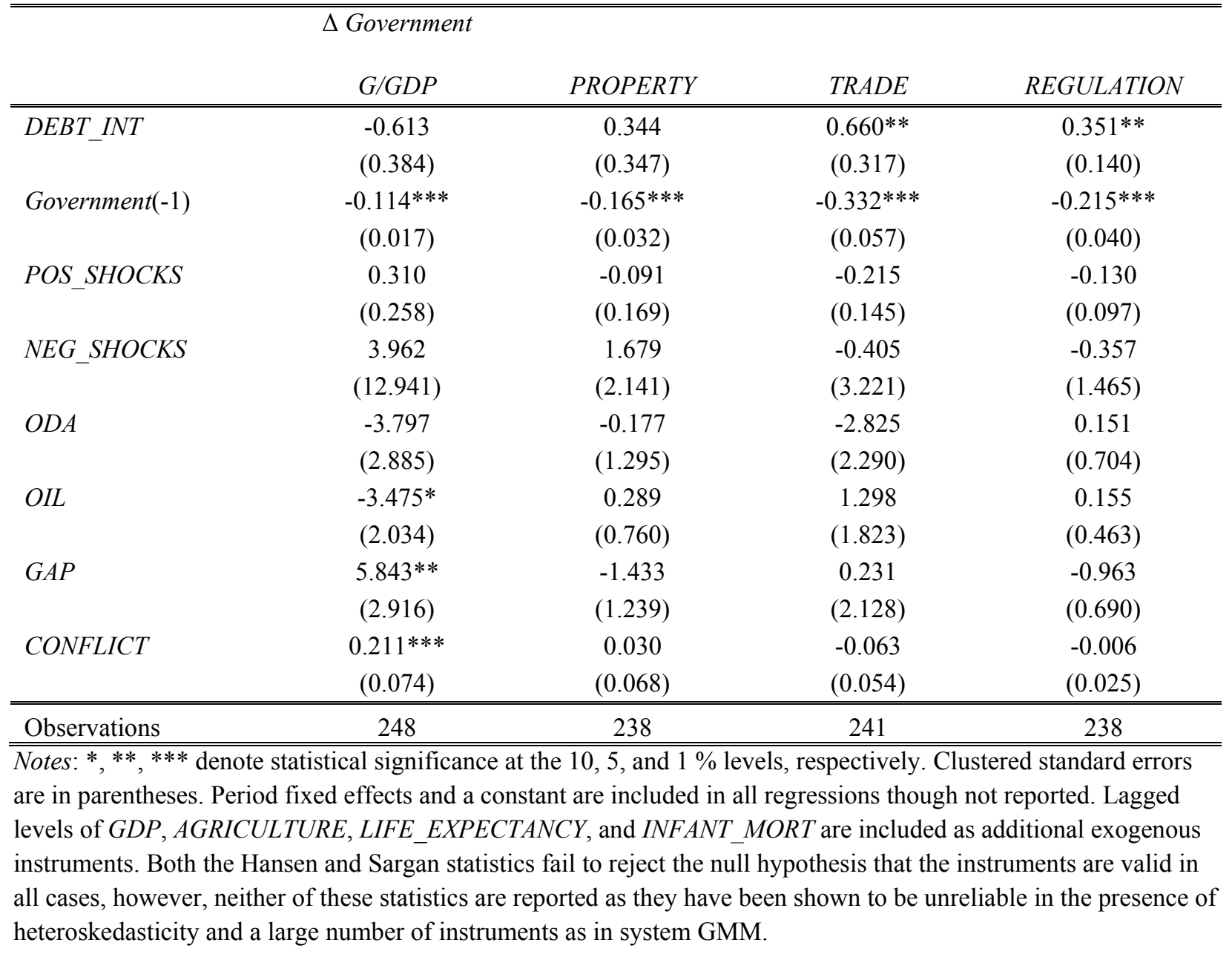


Table A24: System GMM effects of currency crises on 5-year changes in government size/scope, 1966-2010: full set of controls and interaction term included.

\begin{tabular}{|c|c|c|c|c|}
\hline & $\Delta$ Governmer & & & \\
\hline & $G / G D P$ & PROPERTY & TRADE & REGULATION \\
\hline CURRENCY & 0.019 & $\begin{array}{c}-0.007 \\
\end{array}$ & -0.034 & $\begin{array}{c}0.037 \\
\end{array}$ \\
\hline & $(0.196)$ & $(0.142)$ & $(0.122)$ & $(0.084)$ \\
\hline Government(-1) & $-0.110 * * *$ & $-0.173 * * *$ & $-0.336^{* * *}$ & $-0.238 * * *$ \\
\hline & $(0.016)$ & $(0.032)$ & $(0.059)$ & $(0.045)$ \\
\hline POS_SHOCKS & 0.262 & -0.080 & $-0.275^{*}$ & -0.128 \\
\hline & $(0.270)$ & $(0.171)$ & $(0.144)$ & $(0.104)$ \\
\hline$N E G \_S H O C K S$ & 5.412 & 0.914 & -0.948 & -1.313 \\
\hline & (12.639) & (2.014) & (3.228) & $(1.630)$ \\
\hline$O D A$ & -3.555 & -0.354 & -2.990 & 0.046 \\
\hline & (2.893) & $(1.310)$ & $(2.301)$ & $(0.737)$ \\
\hline OIL & $-4.907 * *$ & 0.452 & 2.025 & 0.355 \\
\hline & $(2.037)$ & $(0.712)$ & $(1.630)$ & $(0.540)$ \\
\hline GAP & $5.841^{*}$ & -1.146 & 0.348 & -1.016 \\
\hline & $(3.055)$ & $(1.380)$ & $(2.181)$ & $(0.759)$ \\
\hline CONFLICT & $0.188^{* *}$ & 0.011 & -0.040 & -0.022 \\
\hline & $(0.073)$ & $(0.076)$ & $(0.077)$ & $(0.025)$ \\
\hline Observations & 248 & 238 & 241 & 238 \\
\hline $\begin{array}{l}\text { Notes: } *, * *, * * * \\
\text { are in parentheses } \\
\text { levels of } G D P, A C \\
\text { instruments. Both } \\
\text { all cases, however } \\
\text { heteroskedasticity }\end{array}$ & $\begin{array}{l}\text { ical significa } \\
\mathrm{d} \text { effects and } \\
E, L I F E_{-} E X \\
\text { and Sargan s } \\
\text { hese statistic } \\
\text { number of in }\end{array}$ & $\begin{array}{l}10,5 \text {, and } 1 \% \\
\text { it are included } \\
C Y \text {, and } I N F A \Lambda \\
\text { iil to reject the } \\
\text { rted as they ha } \\
\text { as in system } C\end{array}$ & $\begin{array}{l}\text { espectively } \\
\text { essions tho } \\
T \text { are includ } \\
\text { thesis that } \\
\text { hown to be }\end{array}$ & $\begin{array}{l}\text { ed standard errors } \\
\text { eported. Lagged } \\
\text { litional exogenous } \\
\text { ments are valid in } \\
\text { e in the presence of }\end{array}$ \\
\hline
\end{tabular}


Table A25: System GMM effects of inflation crises on 5-year changes in government size/scope, 1966-2010: full set of controls and interaction term included.

\begin{tabular}{|c|c|c|c|c|}
\hline & $\begin{array}{c}\Delta \text { Government } \\
G / G D P\end{array}$ & PROPERTY & TRADE & REGULATION \\
\hline \multirow[t]{2}{*}{ INFLATION } & -0.332 & -0.270 & -0.277 & -0.021 \\
\hline & $(0.308)$ & $(0.206)$ & $(0.283)$ & $(0.145)$ \\
\hline \multirow[t]{2}{*}{ Government(-1) } & $-0.108 * * *$ & $-0.182 * * *$ & $-0.356^{* * *}$ & $-0.240 * * *$ \\
\hline & $(0.015)$ & $(0.033)$ & $(0.068)$ & $(0.047)$ \\
\hline \multirow[t]{2}{*}{ POS_SHOCKS } & 0.244 & -0.104 & $-0.319 * *$ & -0.120 \\
\hline & $(0.267)$ & $(0.168)$ & $(0.153)$ & $(0.105)$ \\
\hline \multirow[t]{2}{*}{$N E G \_S H O C K S$} & 4.497 & 1.093 & -1.185 & -1.301 \\
\hline & $(12.820)$ & $(1.825)$ & (3.324) & $(1.565)$ \\
\hline \multirow[t]{2}{*}{$O D A$} & -3.719 & -0.312 & -2.786 & -0.001 \\
\hline & $(2.854)$ & $(1.190)$ & (2.187) & $(0.728)$ \\
\hline \multirow[t]{2}{*}{ OIL } & $-3.969^{*}$ & 0.661 & 2.078 & 0.547 \\
\hline & $(2.016)$ & $(0.754)$ & (1.673) & $(0.554)$ \\
\hline \multirow[t]{2}{*}{$G A P$} & $5.721^{*}$ & -1.240 & 0.038 & -1.068 \\
\hline & (2.964) & $(1.278)$ & (2.098) & $(0.737)$ \\
\hline \multirow[t]{2}{*}{ CONFLICT } & $0.164 * *$ & 0.001 & -0.069 & -0.013 \\
\hline & $(0.078)$ & $(0.074)$ & $(0.077)$ & $(0.025)$ \\
\hline Observations & 248 & 238 & 241 & 238 \\
\hline \multicolumn{5}{|c|}{$\begin{array}{l}\text { Notes: }{ }^{*}, * * * * * \text { denote statistical significance at the } 10,5 \text {, and } 1 \% \text { levels, respectively. Clustered standard errors } \\
\text { are in parentheses. Period fixed effects and a constant are included in all regressions though not reported. Lagged } \\
\text { levels of GDP, AGRICULTURE, LIFE_EXPECTANCY, and INFANT_MORT are included as additional exogenous } \\
\text { instruments. Both the Hansen and Sargan statistics fail to reject the null hypothesis that the instruments are valid in } \\
\text { all cases, however, neither of these statistics are reported as they have been shown to be unreliable in the presence of } \\
\text { heteroskedasticity and a large number of instruments as in system GMM. }\end{array}$} \\
\hline
\end{tabular}


Table A26: System GMM effects of banking crises on 10-year changes in government size/scope, 1961-2010: full set of controls and interaction term included.

\begin{tabular}{|c|c|c|c|c|}
\hline \multicolumn{5}{|c|}{$\Delta$ Government } \\
\hline & $G / G D P$ & PROPERTY & TRADE & REGULATION \\
\hline \multirow[t]{2}{*}{$B A N K$} & 0.336 & -0.044 & -0.090 & -0.185 \\
\hline & $(0.647)$ & $(0.235)$ & $(0.199)$ & $(0.136)$ \\
\hline \multirow[t]{2}{*}{ Government(-1) } & $-0.233 * *$ & $-0.285 * * *$ & $-0.551 * * *$ & $-0.373 * * *$ \\
\hline & $(0.095)$ & $(0.073)$ & $(0.109)$ & $(0.080)$ \\
\hline \multirow[t]{2}{*}{ POS_SHOCKS } & -0.365 & -0.143 & 0.032 & 0.030 \\
\hline & $(0.635)$ & $(0.365)$ & $(0.404)$ & $(0.181)$ \\
\hline \multirow[t]{2}{*}{$N E G \_S H O C K S$} & 4.885 & -2.474 & -9.297 & 1.137 \\
\hline & $(23.081)$ & $(9.673)$ & $(9.900)$ & $(5.741)$ \\
\hline \multirow[t]{2}{*}{$O D A$} & $-12.971 * *$ & -3.986 & $-12.550 * * *$ & 0.822 \\
\hline & $(5.081)$ & $(5.050)$ & (3.894) & $(2.279)$ \\
\hline \multirow[t]{2}{*}{$O I L$} & 6.396 & -4.500 & 3.984 & -1.486 \\
\hline & (7.383) & $(3.589)$ & $(3.451)$ & $(2.078)$ \\
\hline \multirow[t]{2}{*}{$G A P$} & 7.317 & 2.143 & 2.374 & $-4.749^{*}$ \\
\hline & (8.784) & $(4.185)$ & (4.197) & $(2.527)$ \\
\hline \multirow[t]{2}{*}{ CONFLICT } & -0.342 & 0.016 & -0.151 & 0.112 \\
\hline & $(0.501)$ & $(0.141)$ & $(0.144)$ & $(0.090)$ \\
\hline Observations & 133 & 126 & 129 & 127 \\
\hline \multicolumn{5}{|c|}{$\begin{array}{l}\text { Notes: }{ }^{* *}, * * * \text { denote statistical significance at the } 10,5 \text {, and } 1 \% \text { levels, respectively. Clustered standard errors } \\
\text { are in parentheses. Period fixed effects and a constant are included in all regressions though not reported. Lagged } \\
\text { levels of GDP, AGRICULTURE, LIFE_EXPECTANCY, and INFANT_MORT are included as additional exogenous } \\
\text { instruments. Both the Hansen and Sargan statistics fail to reject the null hypothesis that the instruments are valid in } \\
\text { all cases, however, neither of these statistics are reported as they have been shown to be unreliable in the presence of } \\
\text { heteroskedasticity and a large number of instruments as in system GMM. }\end{array}$} \\
\hline
\end{tabular}


Table A27: System GMM effects of external debt crises on 10-year changes in government size/scope, 1961-2010: full set of controls and interaction term included.

\begin{tabular}{|c|c|c|c|c|}
\hline & $\Delta$ Governmer & & & \\
\hline & $G / G D P$ & PROPERTY & TRADE & REGULATION \\
\hline$\overline{D E B T \_E X T}$ & -0.043 & $\begin{array}{c}-0.277 \\
\end{array}$ & 0.020 & 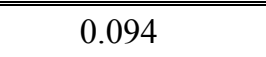 \\
\hline & $(0.431)$ & $(0.390)$ & $(0.316)$ & $(0.145)$ \\
\hline Government(-1) & $-0.242 * *$ & $-0.261 * * *$ & $-0.629 * * *$ & $-0.391 * * *$ \\
\hline & $(0.091)$ & $(0.075)$ & $(0.131)$ & $(0.085)$ \\
\hline POS_SHOCKS & -0.558 & -0.225 & 0.002 & -0.006 \\
\hline & $(0.539)$ & $(0.352)$ & $(0.326)$ & $(0.167)$ \\
\hline$N E G \_S H O C K S$ & 11.059 & -2.620 & -9.010 & 1.684 \\
\hline & $(20.031)$ & (7.195) & $(11.251)$ & $(5.610)$ \\
\hline$O D A$ & $-10.578^{* *}$ & -5.101 & $-10.990 * * *$ & 0.440 \\
\hline & $(4.375)$ & $(4.315)$ & $(3.945)$ & (2.114) \\
\hline OIL & 3.737 & -3.950 & 2.069 & -2.018 \\
\hline & $(6.910)$ & (3.696) & (3.320) & $(2.220)$ \\
\hline GAP & 4.242 & 5.345 & -0.186 & $-5.390 * *$ \\
\hline & $(5.484)$ & (3.207) & $(3.462)$ & $(2.338)$ \\
\hline CONFLICT & -0.201 & 0.011 & -0.124 & 0.138 \\
\hline & $(0.350)$ & $(0.118)$ & $(0.135)$ & $(0.099)$ \\
\hline Observations & 133 & 126 & 129 & 127 \\
\hline $\begin{array}{l}\text { Notes: } *, * *, * * * \\
\text { are in parentheses } \\
\text { levels of } G D P, A C \\
\text { instruments. Both } \\
\text { all cases, however } \\
\text { heteroskedasticity }\end{array}$ & $\begin{array}{l}\text { ical significa } \\
\mathrm{d} \text { effects and } \\
E, L I F E_{-} E X \\
\text { and Sargan s } \\
\text { hese statistic } \\
\text { number of in }\end{array}$ & $\begin{array}{l}10,5 \text {, and } 1 \% \\
\text { it are included } \\
C Y \text {, and } I N F A \Lambda \\
\text { iil to reject the } \\
\text { rted as they ha } \\
\text { as in system } C\end{array}$ & $\begin{array}{l}\text { espectively. } \\
\text { ressions thou } \\
T \text { are include } \\
\text { othesis that th } \\
\text { hown to be } \mathrm{u}\end{array}$ & $\begin{array}{l}\text { ed standard errors } \\
\text { eported. Lagged } \\
\text { litional exogenous } \\
\text { ments are valid in } \\
\text { e in the presence of }\end{array}$ \\
\hline
\end{tabular}


Table A28: System GMM effects of internal debt crises on 10-year changes in government size/scope, 1961-2010: full set of controls and interaction term included.

\begin{tabular}{|c|c|c|c|c|}
\hline \multicolumn{5}{|c|}{$\Delta$ Government } \\
\hline & $G / G D P$ & PROPERTY & TRADE & REGULATION \\
\hline \multirow[t]{2}{*}{$D E B T \_I N T$} & -0.274 & -0.292 & -0.111 & 0.391 \\
\hline & $(0.490)$ & $(0.405)$ & $(0.396)$ & $(0.243)$ \\
\hline \multirow[t]{2}{*}{ Government(-1) } & $-0.254 * * *$ & $-0.268 * * *$ & $-0.549 * * *$ & $-0.383 * * *$ \\
\hline & $(0.087)$ & $(0.073)$ & $(0.113)$ & $(0.083)$ \\
\hline \multirow[t]{2}{*}{ POS_SHOCKS } & -0.871 & -0.281 & -0.291 & 0.081 \\
\hline & $(0.647)$ & $(0.429)$ & $(0.356)$ & $(0.169)$ \\
\hline \multirow[t]{2}{*}{$N E G \_S H O C K S$} & 16.542 & -3.870 & -7.252 & 1.057 \\
\hline & (18.178) & $(8.502)$ & $(9.735)$ & $(5.757)$ \\
\hline \multirow[t]{2}{*}{$O D A$} & $-9.784 *$ & -4.971 & $-11.867 * * *$ & 0.530 \\
\hline & (5.304) & (5.494) & (3.635) & $(2.465)$ \\
\hline \multirow[t]{2}{*}{$O I L$} & -1.688 & -3.728 & 4.068 & -1.332 \\
\hline & $(6.107)$ & $(4.462)$ & (3.642) & $(2.247)$ \\
\hline \multirow[t]{2}{*}{$G A P$} & 9.348 & 6.111 & 0.977 & $-5.592 *$ \\
\hline & $(10.667)$ & $(5.241)$ & (4.564) & (3.293) \\
\hline \multirow[t]{2}{*}{ CONFLICT } & -0.233 & -0.030 & -0.167 & 0.099 \\
\hline & $(0.414)$ & $(0.146)$ & $(0.135)$ & $(0.067)$ \\
\hline Observations & 133 & 126 & 129 & 127 \\
\hline \multicolumn{5}{|c|}{$\begin{array}{l}\text { Notes: }{ }^{* *},{ }^{* * *} \text { denote statistical significance at the } 10,5 \text {, and } 1 \% \text { levels, respectively. Clustered standard errors } \\
\text { are in parentheses. Period fixed effects and a constant are included in all regressions though not reported. Lagged } \\
\text { levels of GDP, AGRICULTURE, LIFE_EXPECTANCY, and INFANT_MORT are included as additional exogenous } \\
\text { instruments. Both the Hansen and Sargan statistics fail to reject the null hypothesis that the instruments are valid in } \\
\text { all cases, however, neither of these statistics are reported as they have been shown to be unreliable in the presence of } \\
\text { heteroskedasticity and a large number of instruments as in system GMM. }\end{array}$} \\
\hline
\end{tabular}


Table A29: System GMM effects of currency crises on 10-year changes in government size/scope, 1961-2010: full set of controls and interaction term included.

\begin{tabular}{|c|c|c|c|c|}
\hline \multicolumn{5}{|c|}{$\Delta$ Government } \\
\hline & $G / G D P$ & PROPERTY & TRADE & REGULATION \\
\hline \multirow[t]{2}{*}{ CURRENCY } & $0.928^{*}$ & 0.168 & 0.339 & $0.298 * *$ \\
\hline & $(0.516)$ & $(0.219)$ & $(0.226)$ & $(0.121)$ \\
\hline \multirow[t]{2}{*}{ Government(-1) } & $-0.237 * *$ & $-0.266 * * *$ & $-0.601 * * *$ & $-0.369 * * *$ \\
\hline & $(0.091)$ & $(0.074)$ & $(0.107)$ & $(0.075)$ \\
\hline \multirow[t]{2}{*}{ POS_SHOCKS } & -0.261 & -0.273 & 0.142 & -0.035 \\
\hline & $(0.622)$ & $(0.390)$ & $(0.403)$ & $(0.196)$ \\
\hline \multirow[t]{2}{*}{$N E G \_S H O C K S$} & -0.722 & -4.182 & -11.195 & 0.609 \\
\hline & $(23.437)$ & (10.004) & $(10.966)$ & (5.894) \\
\hline \multirow[t]{2}{*}{$O D A$} & $-12.400 * *$ & -4.048 & $-10.873 * * *$ & 0.891 \\
\hline & $(5.269)$ & $(5.102)$ & $(4.066)$ & $(2.022)$ \\
\hline \multirow[t]{2}{*}{ OIL } & 5.676 & -3.194 & 3.612 & -1.529 \\
\hline & $(7.555)$ & $(4.550)$ & (3.449) & $(1.836)$ \\
\hline \multirow[t]{2}{*}{$G A P$} & 6.706 & 4.298 & -0.758 & $-5.342 * *$ \\
\hline & $(8.370)$ & $(5.006)$ & $(4.529)$ & $(2.239)$ \\
\hline \multirow[t]{2}{*}{ CONFLICT } & -0.442 & -0.034 & -0.141 & 0.090 \\
\hline & $(0.535)$ & $(0.179)$ & $(0.146)$ & $(0.088)$ \\
\hline Observations & 133 & 126 & 129 & 127 \\
\hline \multicolumn{5}{|c|}{$\begin{array}{l}\text { Notes: }{ }^{* *}, * * * \text { denote statistical significance at the } 10,5 \text {, and } 1 \% \text { levels, respectively. Clustered standard errors } \\
\text { are in parentheses. Period fixed effects and a constant are included in all regressions though not reported. Lagged } \\
\text { levels of GDP, AGRICULTURE, LIFE_EXPECTANCY, and INFANT_MORT are included as additional exogenous } \\
\text { instruments. Both the Hansen and Sargan statistics fail to reject the null hypothesis that the instruments are valid in } \\
\text { all cases, however, neither of these statistics are reported as they have been shown to be unreliable in the presence of } \\
\text { heteroskedasticity and a large number of instruments as in system GMM. }\end{array}$} \\
\hline
\end{tabular}


Table A30: System GMM effects of inflation crises on 10-year changes in government size/scope, 1961-2010: full set of controls and interaction term included.

\begin{tabular}{|c|c|c|c|c|}
\hline \multicolumn{5}{|c|}{$\Delta$ Government } \\
\hline & $G / G D P$ & PROPERTY & TRADE & REGULATION \\
\hline \multirow[t]{2}{*}{ INFLATION } & -0.352 & -0.054 & $0.541^{*}$ & 0.140 \\
\hline & $(0.414)$ & $(0.261)$ & $(0.299)$ & $(0.175)$ \\
\hline \multirow[t]{2}{*}{ Government(-1) } & $-0.262 * * *$ & $-0.306 * * *$ & $-0.546^{* * *}$ & $-0.346 * * *$ \\
\hline & $(0.077)$ & $(0.082)$ & $(0.110)$ & $(0.087)$ \\
\hline \multirow[t]{2}{*}{ POS_SHOCKS } & -1.074 & -0.087 & 0.022 & -0.087 \\
\hline & $(0.645)$ & $(0.324)$ & $(0.353)$ & $(0.170)$ \\
\hline \multirow[t]{2}{*}{$N E G \_S H O C K S$} & 18.148 & -3.944 & -10.086 & 1.391 \\
\hline & $(22.683)$ & (7.648) & $(9.573)$ & $(5.456)$ \\
\hline \multirow[t]{2}{*}{$O D A$} & $-9.759 * *$ & -6.019 & $-11.593 * * *$ & 0.829 \\
\hline & $(4.503)$ & $(5.026)$ & $(3.762)$ & (1.945) \\
\hline \multirow[t]{2}{*}{$O I L$} & -2.790 & -1.901 & 2.530 & -0.851 \\
\hline & (7.512) & $(3.647)$ & (3.313) & $(2.053)$ \\
\hline \multirow[t]{2}{*}{$G A P$} & 14.360 & 1.616 & 0.094 & $-5.716^{* *}$ \\
\hline & $(10.155)$ & $(4.599)$ & (4.489) & $(2.435)$ \\
\hline \multirow[t]{2}{*}{ CONFLICT } & -0.212 & -0.094 & -0.124 & 0.134 \\
\hline & $(0.359)$ & $(0.201)$ & $(0.142)$ & $(0.101)$ \\
\hline Observations & 133 & 126 & 129 & 127 \\
\hline \multicolumn{5}{|c|}{$\begin{array}{l}\text { Notes: }{ }^{* *}, * * * \text { denote statistical significance at the } 10,5 \text {, and } 1 \% \text { levels, respectively. Clustered standard errors } \\
\text { are in parentheses. Period fixed effects and a constant are included in all regressions though not reported. Lagged } \\
\text { levels of GDP, AGRICULTURE, LIFE_EXPECTANCY, and INFANT_MORT are included as additional exogenous } \\
\text { instruments. Both the Hansen and Sargan statistics fail to reject the null hypothesis that the instruments are valid in } \\
\text { all cases, however, neither of these statistics are reported as they have been shown to be unreliable in the presence of } \\
\text { heteroskedasticity and a large number of instruments as in system GMM. }\end{array}$} \\
\hline
\end{tabular}

